Portland State University

PDXScholar

\title{
Food Delivery Footprint: Addressing Transportation, Packaging, and Waste in the Food Supply Chain
}

\author{
Madeleine E. Pullman \\ Portland State University, mpullman@pdx.edu \\ Robin Fenske \\ Portland State University \\ Wayne Wakeland \\ Portland State University, wakeland@pdx.edu
}

Follow this and additional works at: https://pdxscholar.library.pdx.edu/busadmin_fac

Part of the Business Commons, Environmental Policy Commons, Sustainability Commons, and the Transportation Commons

\section{Let us know how access to this document benefits you.}

\begin{abstract}
Citation Details
Pullman, Madeleine E., Robin Fenske, and Wayne Wakeland. Food Delivery Footprint: Addressing Transportation, Packaging, and Waste in the Food Supply Chain. OTREC-RR-10-06. Portland, OR: Transportation Research and Education Center (TREC), 2010. http://dx.doi.org/10.15760/trec.129
\end{abstract}

This Report is brought to you for free and open access. It has been accepted for inclusion in Business Faculty Publications and Presentations by an authorized administrator of PDXScholar. Please contact us if we can make this document more accessible: pdxscholar@pdx.edu. 


\section{SOTREC}

FINAL REPORT

\section{Food Delivery Footprint: Addressing Transportation, Packaging, and Waste in the Food Supply Chain}

OTREC-RR-10-06

June 2010 



\title{
FOOD DELIVERY FOOTPRINT: ADDRESSING TRANSPORTATION, PACKAGING, AND WASTE IN THE FOOD SUPPLY CHAIN
}

\author{
Final Report \\ OTREC-RR-10-06
}

by

\author{
Madeleine E. Pullman \\ Robin Fenske \\ Wayne Wakeland
}

Portland State University

Portland, OR

for

Oregon Transportation Research

and Education Consortium (OTREC)

P.O. Box 751

Portland, OR 97207

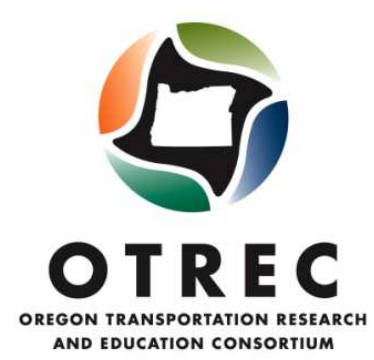

June 2010 



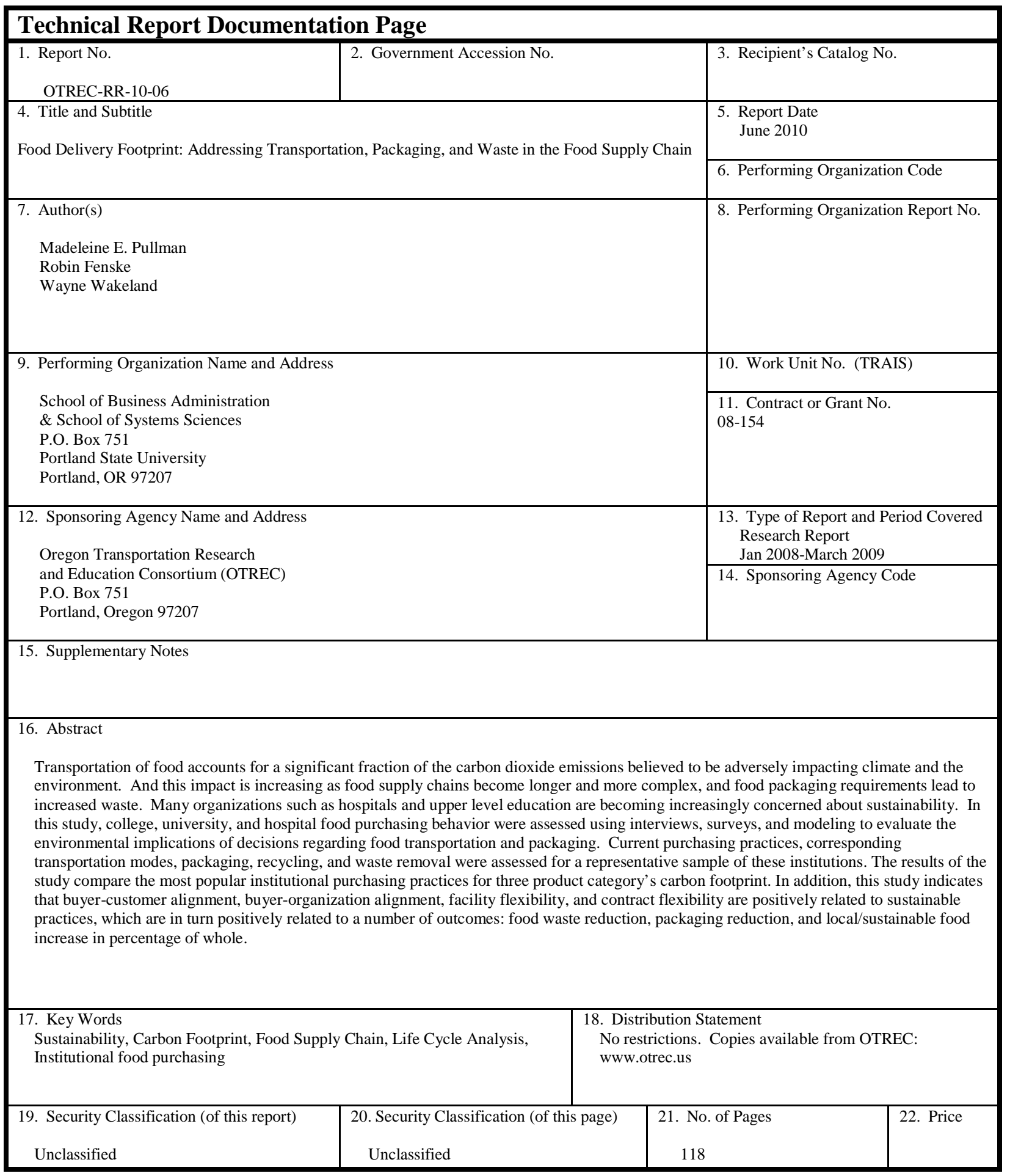





\section{ACKNOWLEDGEMENTS}

This project was funded by the Oregon Transportation Research and Education Consortium (OTREC), Portland State Sustainability Research Grant, School of Business Administration, and Systems Sciences.

\section{DISCLAIMER}

The contents of this report reflect the views of the authors, who are solely responsible for the facts and the accuracy of the material and information presented herein. This document is disseminated under the sponsorship of the U.S. Department of Transportation University Transportation Centers Program and Portland State University in the interest of information exchange. The U.S. Government and Portland State University assumes no liability for the contents or use thereof. The contents do not necessarily reflect the official views of the U.S. Government and Portland State University. This report does not constitute a standard, specification, or regulation. 



\section{TABLE OF CONTENTS}

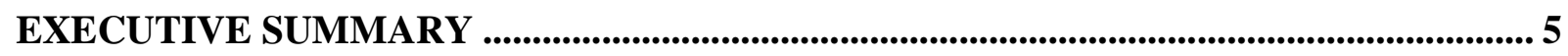

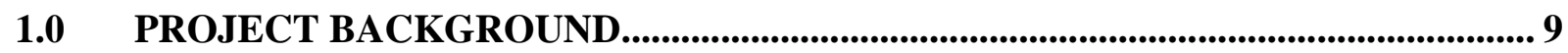

1.1 SHIFTING FOOD PURCHASING POLICIES' RELATION TO TRANSPORTATION

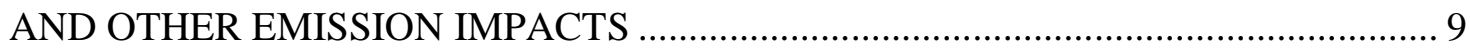

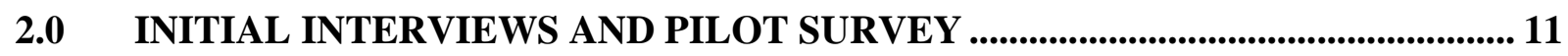

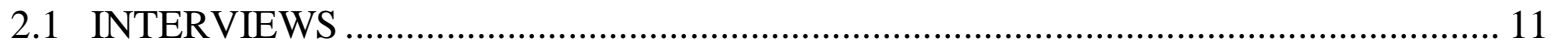

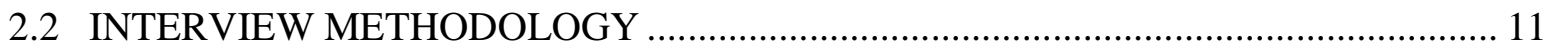

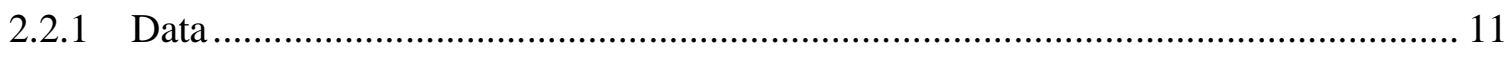

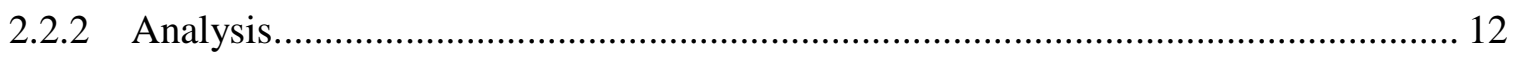

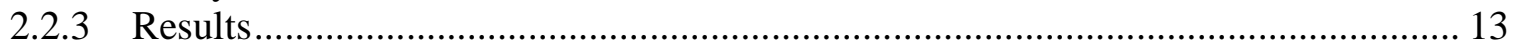

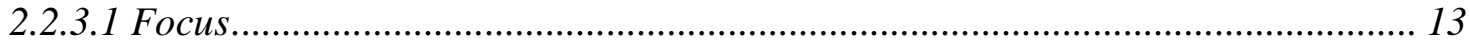

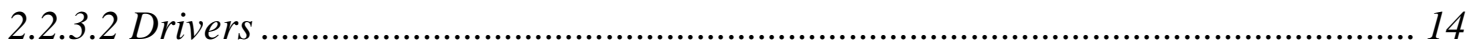

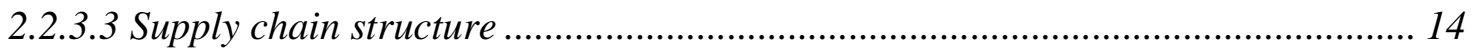

2.2.3.3.1 Institution food purchasing policy \& contracts ....................................... 14

2.2.3.3.2 Third-party purchasing relationships \& contracts .................................... 15

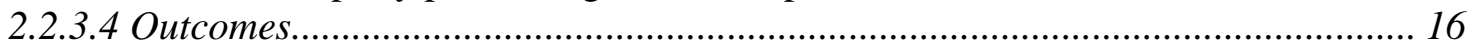

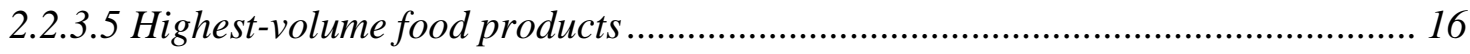

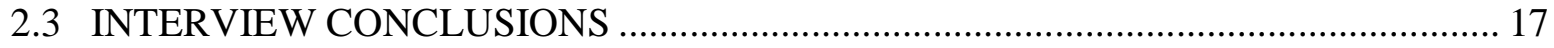

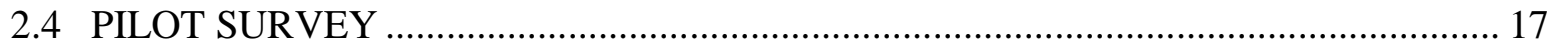

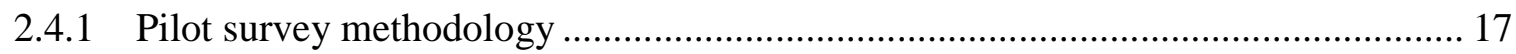

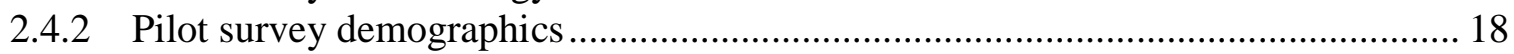

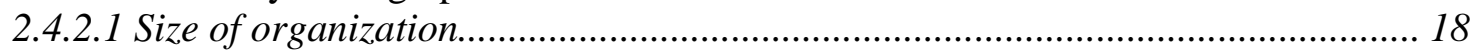

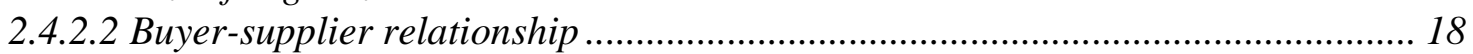

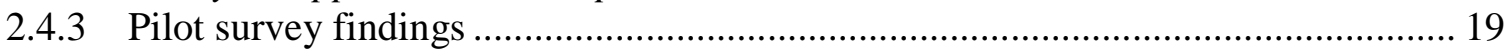

2.4.3.1 Participant's priorities in purchasing decisions, ranking seven possible priorities 19

2.4.3.2 Respondent's priorities in purchasing decisions within their particular

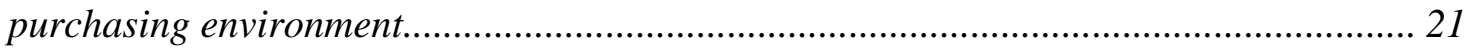

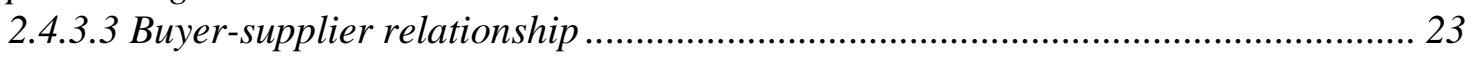

2.4.3.4 Obstacles to adopting different purchasing practices ......................................... 25

2.4.3.5 Purchasing processed foods and on-site facilities for processing ....................... 27

2.4.3.6 Food purchased with sustainable characteristics............................................... 28

2.4.3.7 Assessing packaging and food waste reduction programs for 10 different types of packaging or food waste, and percent reduced if program is implemented...................... 28

2.4.3.8 Product mix and packaging characteristics ........................................................ 30

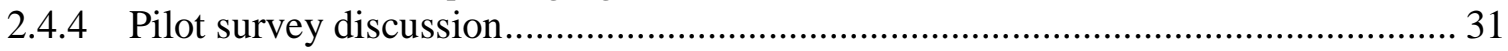

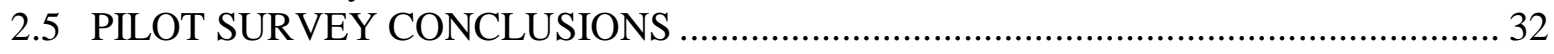

3.0 INSTITUTIONAL CONTEXT AND PRACTICES (FINAL) SURVEY .................. 33

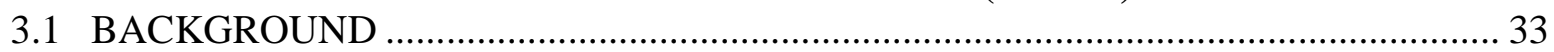

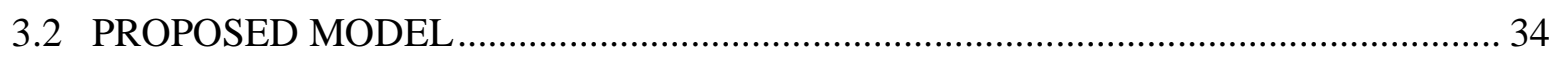

3.3 FINAL SURVEY RESEARCH METHODOLOGY ….............................................. 36

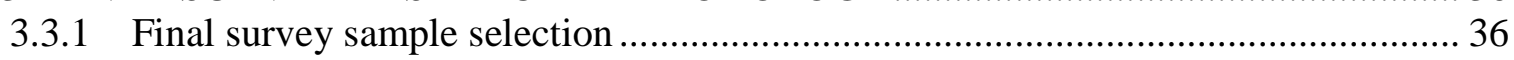

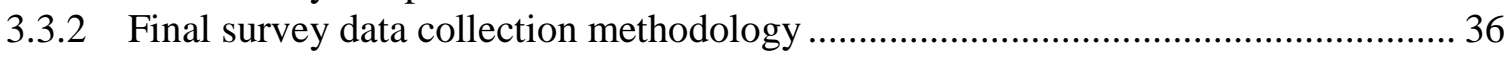




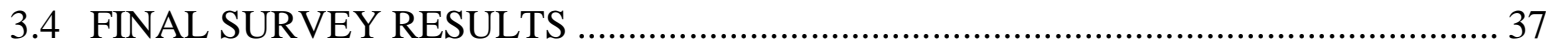

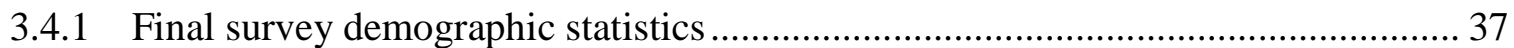

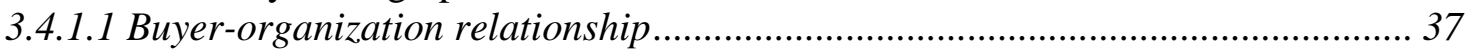

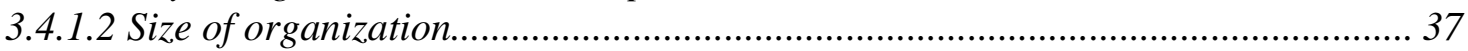

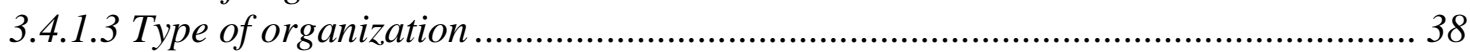

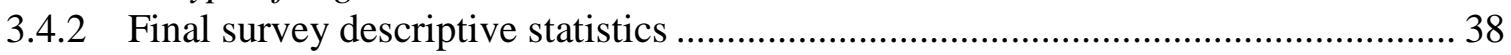

3.4.2.1 Perceived priorities of host organization, end customer, and food purchasing

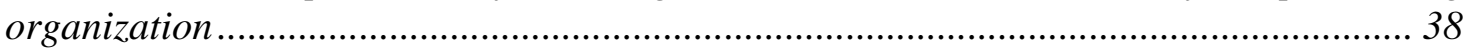

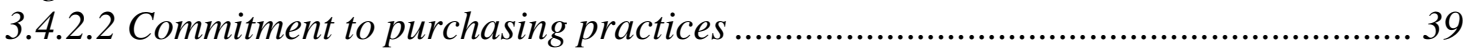

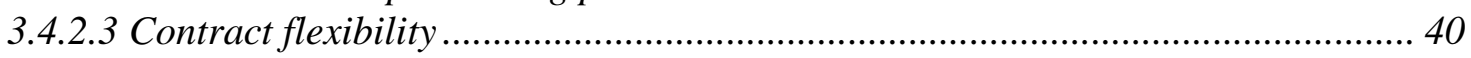

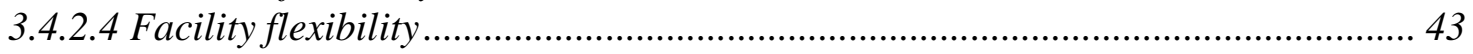

3.4.2.5 Recycling, reuse, and waste (composting and donation)..................................... 44

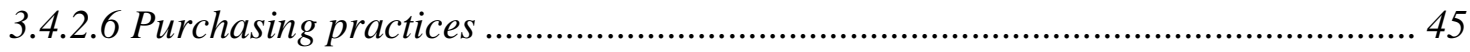

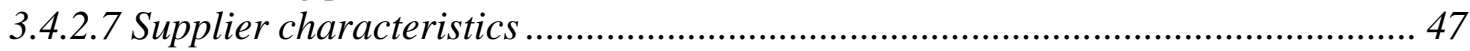

3.4.3 Final survey alignment between host organization, end customer and food

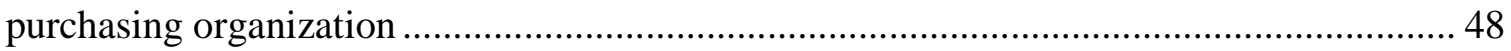

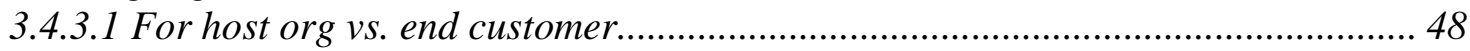

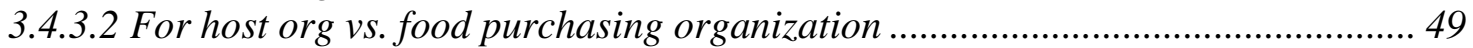

3.4.3.3 For end customer vs. food purchasing organization ........................................ 50

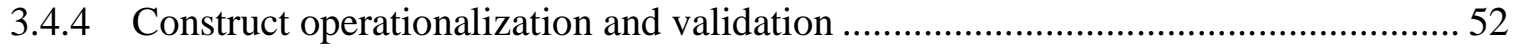

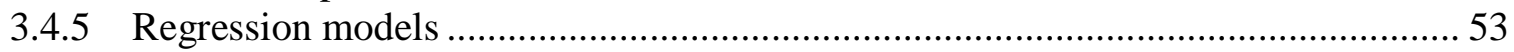

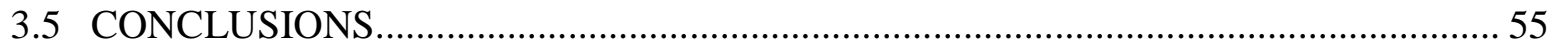

4.0 LIFE-CYCLE EMISSIONS OF HIGH-VOLUME PRODUCTS ANALYSIS......... 57

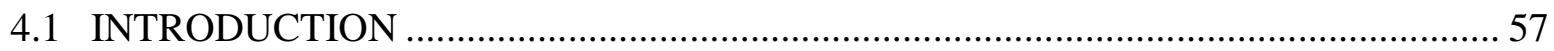

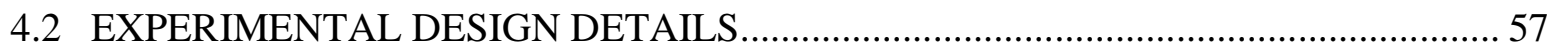

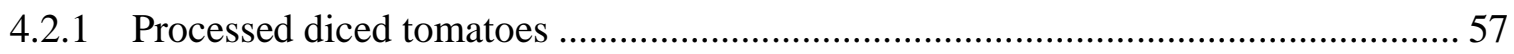

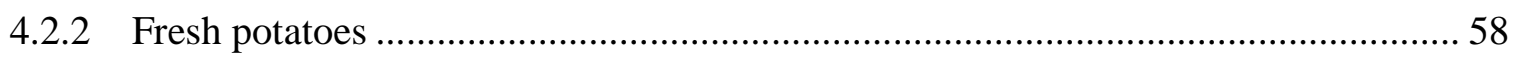

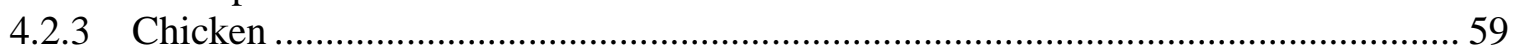

4.3 LIFE-CYCLE CARBON ASSESSMENT METHOD …........................................... 59

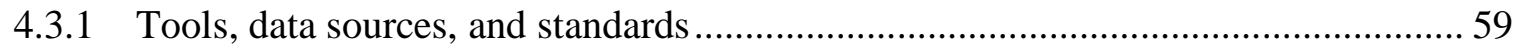

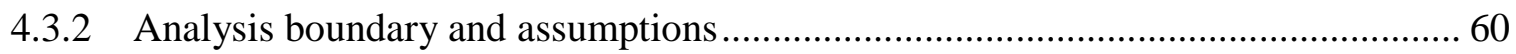

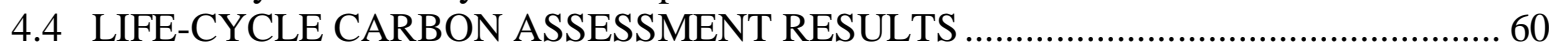

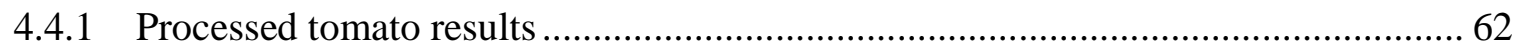

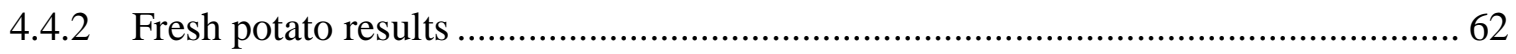

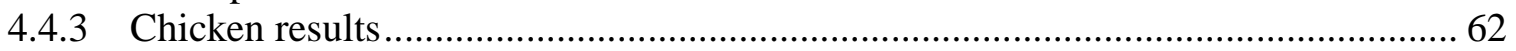

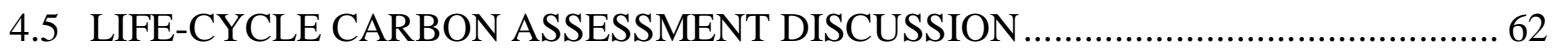

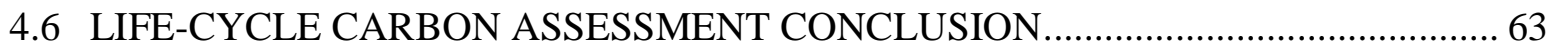

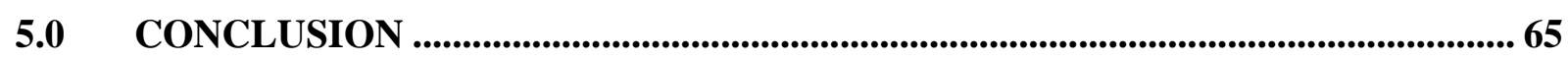

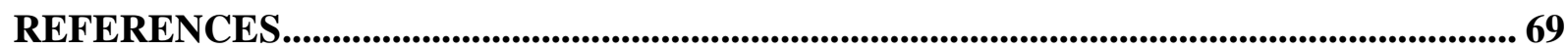

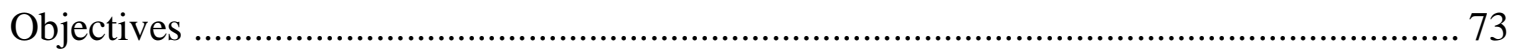

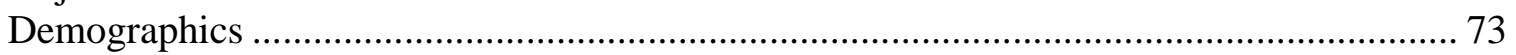

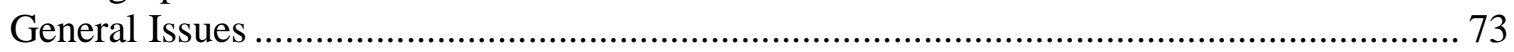

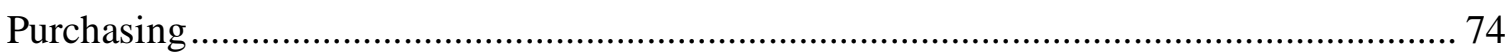

Business model, government regulations, third-party certification ................................ 74 


\section{APPENDICES}

APPENDIX A-1: INTERVIEW PROTOCAL

APPENDIX A-2: PILOT SURVEY INSTRUMENT

APPENDIX A-3: FINAL SURVEY INSTRUMENT

APPENDIX A-4: DETAILS OF THE METHODS EMPLOYED FOR THE LIFE-CYCLE ANALYSIS

\section{LIST OF TABLES}

Table 2.1 Summary of participant's ranking of priorities in purchasing decisions

Table 2.2 Summary of respondent's priorities in purchasing decisions, from understanding of food purchasing organization

Table 2.3 Summary of respondent's perceived end customer priorities.

Table 2.4 t-test of respondent's perceived priorities of their food purchasing organization compared to their end customer

Table 2.5 Respondent's mean percentages of purchases from different types of suppliers ......... 24

Table 2.6 Comparing means of extent to which issue is obstacle to adopting sustainable food purchasing

Table 2.7 Comparing means of extent to which issue is obstacle to reducing food packing waste

27

Table 2.8 Percentages of purchases that are processed food, by type of processed food............. 28

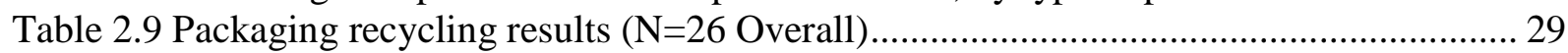

Table 2.10 Non-packaging recycling, reuse, and composting results $(\mathrm{N}=26$ Overall)............... 30

Table 2.11 Most significant food items and their packaging characteristics $(\mathrm{N}=26) \ldots \ldots \ldots \ldots \ldots \ldots . . . . . .31$

Table 2.12 Estimated current overall status of food packaging recycling ................................ 31

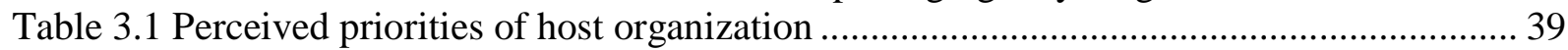

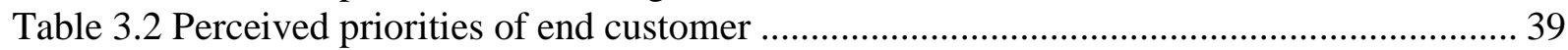

Table 3.3 Perceived priorities of food purchasing organization ................................................ 40

Table 3.4 Support of dominant supplier for sustainable practices ............................................. 41

Table 3.5 Host organization support of sustainable practices (for contracted employees) .......... 42

Table 3.6 Host organization support of sustainable practices (for host org employees) .............. 43

Table 3.7 Results for recycling, reuse, food composting, and food donation for final survey

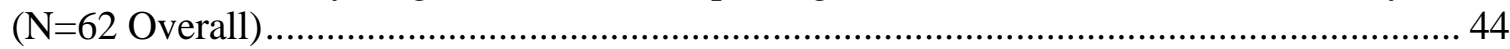

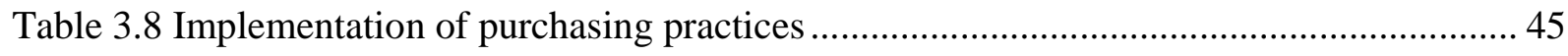

Table 3.9 Purchasing practices as percentage of total if implemented ....................................... 46

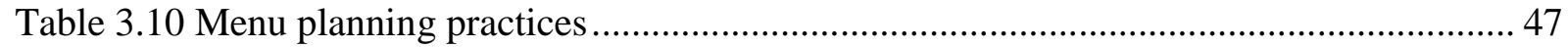

Table 3.11 Menu planning practices as percentage of total if implemented .............................. 47

Table 3.12 t-test of respondent's perceived priorities of their host organization compared to their

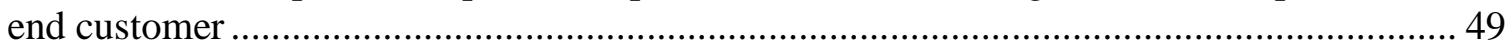

Table 3.13 t-test of respondent's perceived priorities of their host organization compared to their

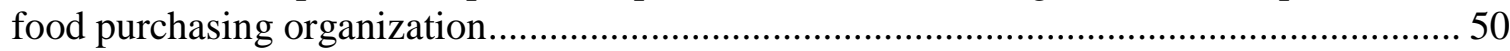

Table 3.14 t-test of respondent's perceived priorities of their end customer compared to their

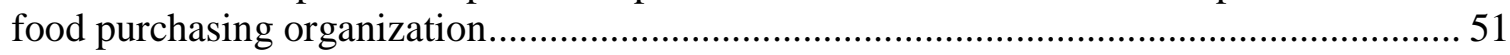

Table 3.15 Summary of perceived priorities t-tests ......................................................... 52

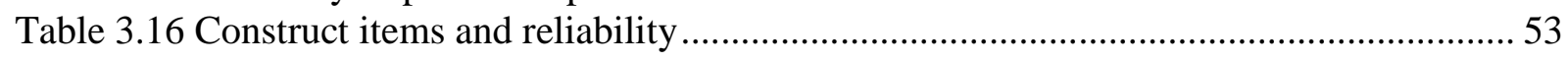


Table 3.17 Stepwise regression of policy formalization and outcomes as a function of values, contract, and facility flexibility

Table 4.1 Life-cycle carbon assessment results for transportation, packaging, and waste alternatives (normalized embodied carbon, $\mathrm{kg} \mathrm{CO}_{2} / \mathrm{kg}$ )

\section{LIST OF FIGURES}

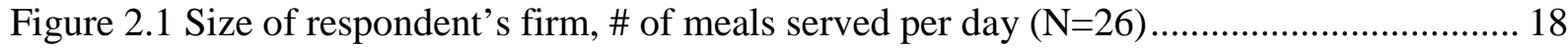

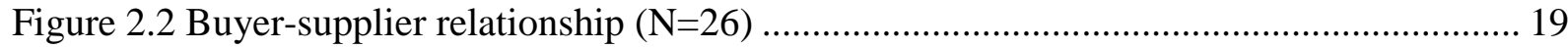

Figure 2.3 Summary of frequency of participant's ranking of priorities on purchasing decisions -

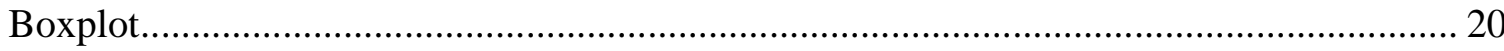

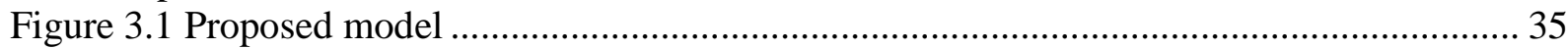

Figure 3.2 Size of the organization for final survey respondents (meals per day) (N=62)......... 37

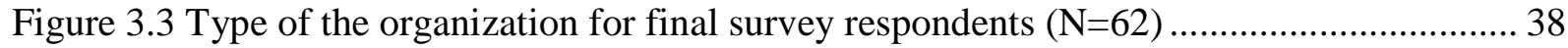




\section{EXECUTIVE SUMMARY}

Rising concern about the environmental impact of food transportation has led many firms to define policies and implement practices that reduce their ecological footprint (Bauccio and Halwell 2005). The policies and practices account for a variety of activities of the product life cycle. In order to develop and manage systems that reduce ecological impact, food retail institutions must maintain collaborative relations with suppliers, transportation and logistics providers, and waste haulers (Piercy and Lane 2006). Tukker (2006) identifies food as one of the top three contributors to the environmental impact in society (the other two are mobility and home energy use). Food transportation, broadly viewed, is a major part of that impact. The centralization of supermarket buying, the globalization and consolidation of the food industry, and the increased usage of regional distribution centers have all contributed to the escalation of food transportation over the past 30 years (Finney 2006).

Pirog and colleagues published two articles that outlined the concept of "food miles" to contrast local and global food supply systems (Pirog 2004; Pirog and Benjamin 2005). Food miles can provide a relative indicator of the amount of energy or fuel used to transport from farm to store, with lower food miles signaling lower transportation fuel usage and cost. Lower food miles also often translate to lower greenhouse gas emissions. Although strong advocacy for local food sourcing existed long before these studies were published, the results of the studies significantly increased the interest in the ecological impacts of local versus global food supply chains.

An important component of the food supply chain is the intermediary food industry that provides, for example, food products to students and hospital patients. This sector requires frequent and lengthy trips by food growers and producers to hubs in a complex food distribution network that contributes significantly to global carbon dioxide emissions (Horrigan, Lawrence, and Walker 2002). Increasingly, these businesses are assessing the impact of their purchasing decisions on their carbon footprints (Min and Galle 2001). Carbon footprint is one way to describe or measure the carbon emissions from a specific organization or process. Purchasing decisions have complex implications for the environment based on the mode of transportation employed, the corresponding packaging used to transport the goods, and the resulting waste and disposal transportation. For example, a hospital may choose to support local farmers and purchase seasonal food products rather than purchasing from large national food suppliers whose products tend to be sourced from multiple producers around the globe. The local farmer may use a pickup truck to service multiple customers with minimal packaging and recyclable totes, whereas the distributor tends to use long- and short-haul trucking with protective packaging that generates more waste and requires additional transportation to haul the waste to landfills.

The objective of the present research is to examine the environmental implications of the purchasing decisions made by the intermediary food industry, as represented by hospitals and upper-level educational institutions. The project has three parts: 1) assess the current institutional food purchasers to assess practices that impact transportation costs, highest food volumes, and food and packaging waste management, 2) determine enablers and obstacles to improving 
purchasing practices to reduce emissions and their impact on local purchasing and waste practices, and 3) conduct an assessment of the life-cycle greenhouse gas emission of three categories of high-volume institutional supply chains, including current "common" methods compared to "potential emission-reduction" methods.

For the first phase, seven food service purchasing managers were interviewed in several different types of institutional settings: both public and private hospitals and universities. The interviews were supplemented by information gathering and clarification interviews with sustainability directors from the two largest U.S. broad-line food distributors; five local produce distributors; two national food service catering companies; a local chain restaurant; and the non-profit groups Health Care without Harm, Food Alliance, Portland Food Policy Council, and Portland Food Purchasing Council. These interviews revealed the major institutional food items with potential for alternative packaging and distribution, packaging styles, weights, and processing locations. In addition, these respondents provided valuable information on potential obstacles to improving emissions related to contracts and current practices. This information was used to develop a pilot survey to gather data from a wider sample of institutional purchasers concerning their current waste management and purchasing practices along with the estimates of highest volume food items in each category, the packaging, and waste management.

Two key concepts were clarified throughout the interview process: 1) Alignment of goals between different stakeholder groups makes for better sustainable purchasing (final customer, organization, purchasing group, food distributors), and 2) Lack of supplier transparency and traceability systems leads to poor reporting systems and limits local purchasing measurement and improvement.

For the second part of the study, the pilot survey was expanded on, to examine the impact of goal alignment and contract and facility flexibility on the adoption of local purchasing and waste reduction and the resulting outcome measures for each. The results show that the host organization and end customer do not always share the same level of commitment to waste reduction practices while they do share commitment to local purchasing. The host organization commitment, resulting level of formal policies, and contract language with a third-party food service provider has significant impact on reducing waste and increasing local purchases. In this study, the facility flexibility was not found to be a significant factor.

In the final part of the study, life-cycle greenhouse gas emission analysis was performed for three popular food commodities (processed tomatoes, fresh potatoes, and chicken) to look at the implications of local versus national production and transportation, alternative packaging, cooking and waste disposal. The results show that policies encouraging the purchase of local food do have some positive impacts on emissions, but are relatively small compared to other considerations when determining the climate impact of food production, consumption, and disposal. Minimizing food waste has a much larger benefit than switching from a distant supplier to a local supplier. Packaging choices showed smaller effects. But, when analyzed carefully, one must conclude that plastic packaging generally has a smaller environmental footprint than steel, paper, or glass due to its low usage volumes and weight. Policy decisions that connect better packaging choices to reduction in emissions, food waste, and perishability clearly create win-win outcomes. 
Ultimately, the results of this study may serve as the foundation for a broader assessment of an organization's carbon footprint, which would extend to other forms of energy usage,

transportation, and materials management. This would represent an enhancement to assessment methodologies based purely on food miles, which assume that greenhouse gases emitted during food transport can be accurately estimated knowing only the distances travelled by the food. This work is intended to build upon and extend food-miles research by 1) focusing on the policies and practices of institutional upper-level education and hospitals, and 2) expanding beyond a foodmiles analysis to include packaging, waste hauling and landfill disposal. 



\subsection{PROJECT BACKGROUND}

\subsection{SHIFTING FOOD PURCHASING POLICIES' RELATION TO TRANSPORTATION AND OTHER EMISSION IMPACTS}

Rising concern about the environmental impact of food transportation has led many firms to define policies and implement practices that reduce their ecological footprint (Bauccio and Halwell 2005). The policies and practices account for a variety of activities of the product life cycle. In order to develop and manage systems that reduce ecological impact, food retail institutions must maintain collaborative relations with suppliers, transportation and logistics providers, and waste haulers (Piercy and Lane 2006). Tukker (2006) identifies food as one of the top three contributors to the environmental impact in society (the other two are mobility and home energy use). Food transportation, broadly viewed, is a major part of that impact. The centralization of supermarket buying, the globalization and consolidation of the food industry and the increased usage of regional distribution centers have all contributed to the escalation of food transportation over the past 30 years (Finney 2006).

Pirog and colleagues published two articles that outlined the concept of "food miles" to contrast local and global food supply systems (Pirog 2004; Pirog and Benjamin 2005). Food miles can provide a relative indicator of the amount of energy or fuel used to transport from farm to store, with lower food miles signaling lower transportation fuel usage and cost. Lower food miles also often translate to lower greenhouse gas emissions. Although strong advocacy for local food sourcing existed long before these studies were published, the results of the studies significantly increased the interest in the ecological impacts of local versus global food supply chains.

An important component of the food supply chain is the intermediary food industry that provides, for example, food products to students and hospital patients. This sector requires frequent and lengthy trips by food growers and producers to hubs in a complex food distribution network that contributes significantly to global carbon dioxide emissions (Horrigan, Lawrence, and Walker 2002). Increasingly, these businesses are assessing the impact of their purchasing decisions on their carbon footprints (Min and Galle 2001). Carbon footprint is one way to describe or measure the carbon emissions from a specific organization or process.

Purchasing decisions have complex implications for the environment based on the mode of transportation employed, the corresponding packaging used to transport the goods, and the resulting waste and disposal transportation. For example, a hospital may choose to support local farmers and purchase seasonal food products rather than purchasing from large national food suppliers whose products tend to be sourced from multiple producers around the globe. The local farmer may use a pickup truck to service multiple customers with minimal packaging and recyclable totes, whereas the distributor tends to use long- and short-haul trucking with protective packaging that generates more waste and requires additional transportation to haul the waste to landfills. 
Increasingly, many institutions are developing informal and formal policies related to all aspects of sustainable purchasing (i.e., decisions related to both the environment and society). These organizations are attempting to incorporate local products into their purchasing decisions with the intention of supporting their regional agricultural systems and those communities associated with the systems. While those making these decisions feel that purchasing local products must reduce transportation distances and hence simultaneously reduce environmental impacts, many other factors can potentially complicate these impacts, such as the local methods of production, packaging waste, food waste connected to packaging and production methods, and packaging and food waste life-cycle emissions.

Thus, the objective of the present research is to examine the environmental implications of the purchasing decisions made by the intermediary food industry, as represented by hospitals and upper-level educational institutions. The project has three parts: 1) assess the current institutional food purchasers to understand current levels of sustainable policy implementation and practices potentially related to transportation, to determine highest food category volumes, and food and packaging waste management changes, 2) determine institutional enablers and obstacles to changing purchasing practices to reduce emissions, and 3) conduct an assessment of the lifecycle greenhouse gas emission of three food categories of high-volume institutional supply chains, including traditional methods compared to those methods perceived to be more "sustainable" in current policies. 


\subsection{INITIAL INTERVIEWS AND PILOT SURVEY}

There are three distinct phases for this research. The first stage involved exploratory semistructured interviews with members of the institutional supply chain and other involved stakeholders followed by a survey. The interviews provided an opportunity to conduct an evaluation of the broad issues that institutions faced when purchasing food products, and efforts they had taken to reduce food transportation (by incorporating locally produced items) and the related packaging and waste reduction.

A pilot survey instrument was created, through information based on the interviews, to gather additional information from a wider sample of participants. Additionally, the empirical data gathered from both of these methods contributed to the development of the second phase, a theoretical model to test the relationship between various contextual factors and the adoption level of purchasing practices and the subsequent waste reduction. Information gathered in this first stage was also used to determine the appropriate three food items for the third phase, the life-cycle greenhouse gas emission analysis.

\section{$2.1 \quad$ INTERVIEWS}

For the first phase, seven food service purchasing managers were interviewed in several different types of institutional settings: both public and private hospitals and universities. The interviews were supplemented by information gathering and clarification interviews with sustainability directors from the two largest U.S. broad-line food distributors; five local produce distributors; two national food service catering companies; a local chain restaurant; and the non-profit groups Health Care without Harm, Food Alliance, Portland Food Policy Council, and Portland Food Purchasing Council.

\subsection{INTERVIEW METHODOLOGY}

Because this study focused on the institutional purchasing supply chain, multiple forms of qualitative data were collected on the opinions, actions, and discourse of multiple members of this chain and the interested non-profit groups, which played key roles in driving food purchasing waste management policies for the chain. The sources included interviews, observation, publications, Web sites, news articles, and purchasing policies. This multi-source approach provided an opportunity to combine information about the experiences and reasoning of the interview participants with the current and historical data.

\subsubsection{Data}

The major portion of these data is seven in-depth interviews with purchasing managers from both public and private institutions, which were conducted between January and March 2008. These interviews started with general demographic questions asking individuals to describe their role and employer. The questions then turned to general purchasing issues and policies related to sustainability (local purchasing and waste); requests for documented policies and reports; and information about the supplier selection process and the impact of supplier and other drivers on local purchasing and waste reduction practices. The final portion of the interview addressed 
specific purchasing issues such as highest-volume food products, waste streams, and problems with packaging and transportation reduction. This section included perceptions of control of packaging problems, existing measures of waste or locally purchased products, and the impact of the business model on purchasing practices.

Most interviews lasted about one hour. The interviewees were identified initially from local institutions (convenience sample) and subsequent snowballing sampling. Purchasing individuals had worked in the waste reduction and sustainable purchasing area for three to four years, and their institutions served between 2,600 and 8,600 meals per day. For the three hospitals, one of the respondents represented a public hospital and two represented private hospitals. Of the four schools, one respondent represented a private school and three represented public schools.

The interview data was supplemented with a comprehensive set of archival data. Current Web sites were accessed from both the purchasing organization and their supply chain members. In addition, seven food suppliers (two national broad-line and five regional produce distributors) were asked to submit any available data on food items purchased locally and their sustainability policy. Short informational interviews were conducted with all of these suppliers to determine the availability of additional measures and any reporting activity related to sustainability. An additional respondent represented a local chain restaurant known for capturing detailed information on packaging, food-miles, and waste.

Finally, members of local non-profits were interviewed or observed their meetings connected to institutional purchasing. These groups included Health Care without Harm, Food Alliance, Portland Food Policy Council, and Portland Food Purchasing Council. In the course of these events, field notes were compiled and informally talked with or listened to numerous leaders of advocacy groups for sustainable purchasing. All aforementioned interviews and observations resulted in over 500 pages of transcribed interviews or field notes.

\subsubsection{Analysis}

The analytical approach is best described as a grounded theory approach. Although it is impossible to approach data without prior expectations or assumptions, the aim was to allow themes to emerge from the data rather than attempting to fit preconceived categories (Lindlof and Taylor 1995). The authors read all transcripts, field notes, and artifacts in their entirety before rereading the data and identifying themes. Based on the observations, identified themes were tentatively identified, which were then explored in the interviews and additional observations. Field notes, interview transcripts, and artifacts were repeatedly read to clarify themes.

Through a constant comparison method (Glaser and Strauss 1967; Corbin and Strauss 1998), the data were grouped into categories and developed labels for the categories or themes. This involved the stages of open and axial coding. Open coding is an inductive process in which data are compared to prior data, looking for similarity or difference. As data are judged to be different, a new coding category is added. Open coding is iterative, and categories are added, combined, and revised in an emergent manner until the coding categories do not require further modification (Creswell 1998). Once open coding was completed, the analysis moved to the second stage of axial coding. In axial coding, the researcher seeks connections among the open 
coding to identify emergent themes while continuously comparing them for similarities and differences. Each time a new theme emerges, a new category is created (Creswell 1998). Two researchers worked independently and then together to check and merge the analyses, which produced few differences, mostly in labeling. Finally, the transcripts and field notes were read again and the analysis checked to ensure the accuracy and consistency of the categories and to look for alternative explanations of the findings (Miles and Huberman 1994).

\subsubsection{Results}

Four broad themes emerge from the data: Focus, Drivers, Structure, and Outcomes. These themes identify divergent motivations; the supply chain structure revealed through contracts, policies, and relationships, and the subsequent practices and outcomes from these organizations.

\subsubsection{Focus}

Depending on the institution, the organization has an overarching focus which could be cost, environment, local food purchasing, and/or safety. Cost is the most significant focus for every respondent. Cost is balanced with other focus areas and is reflected in the decision to purchase locally and to change menu design and packaging. Thus, purchasing from a closer supplier or lower waste packaging decisions are predominately based on cost considerations.

Purchasing from local suppliers is also important to all respondents. But, local foods must have comparable products and price to sway the choice from the nationally distributed products. Typically, the institutions believe that promoting local food is an interest of their consumers. The main reasoning behind purchasing local food is that local purchasing supports local farms and the regional economy and reduces the food-miles traveled. All purchasing people indicated that it was crucial that the local food purchases are conveyed to the end consumer to reap full benefits since typically the consumer pays more for that product.

Environmental impacts were a focus for hospitals. Hospital respondents are concerned for the environment because they recognize their impacts as a large entity and feel responsible for the health implications of environmental waste. They spoke of balancing the budget and the environment together. Both packaging and food waste were of particular concern.

Finally, hospitals spoke of food nutrition and safety as another concern. Patient menus do not have much flexibility in terms of addressing certain nutritional requirements or special diets. But, food safety is a higher priority than cost. Often, packaging considerations such as individual-portion packaged food items are connected to this focus. These packages are perceived to be safer and nutritionally controlled yet more expensive and environmentally less appealing. 


\subsubsection{Drivers}

Different parties are perceived to be the key drivers of sustainable purchasing activities. From all perspectives, the end customer drives the supply chain decisions. The university purchasing respondents refer to pressure and demand from their students, students' parents, and staff who want locally produced, healthy, and organic food. This pressure drives the institution to develop sustainable food programs, reduce waste, and eliminate fast-food cafeteria vendors such as Taco Bell. The private schools allocate more money to these efforts than the public schools. Students are involved with writing food service contracts and policy.

In the hospital environment, the respondents have surveyed their customers and found that most want locally purchased food and will pay more for it. The purchasing respondents feel that they must respond to customer demand, that this forces their purchasing group to change, and subsequently, has forced the large national distributors to respond to their demands for waste reduction and local foods.

Similarly, the institutional leadership - particularly the presidents - view sustainability as part of their mission and this is reflected in their policies, goals, and other formalized organizational publications. The food service providers (such as Aramark) feel that they must try to fit with these cultures and attempt to align their policies with the institution to gain contracts. One respondent mentioned that their operation would look completely different at a rural school versus the Portland campus because of the different cultures.

Finally, special interest groups are another active party that influences purchasing. For example, some hospital employees are members of the groups Hospitals for a Healthy Future or Health Care without Harm, while universities have a group called Real Food Challenge. All of these groups are national social networks that focus on waste reduction and purchasing of local, organic, and/or minimally processed foods. They contribute ideas and a voice for change. Another group that influences local purchasing at VA hospitals is local veterans. Their businesses are given preferential treatment where cost is not a factor.

\subsubsection{Supply chain structure}

The supply chain structure refers to the configuration and power relationships between the host organization (either a school or hospital); the purchasing organization (either an employee organization or a subcontracted, third-party, food service provider); the purchasing organization's membership in a group purchasing organization; and the various food distributors. Between these various parties, typically a contract exists that either constrains or promotes the ability to purchase locally or reduce various waste streams.

\subsection{Institution food purchasing policy \& contracts}

The host institutions develop their own contracts and/or policies pertaining to food purchasing. These contracts are typically developed by a contract advisory board 
composed of multiple stakeholders. For schools, these include students, faculty, staff, residence halls, catering customers, and other interested stakeholders. For hospitals, employees are involved in developing contracts, but the food service typically uses surveys to gather input from patients, visitors, and other staff. These contracts have included requirements for waste reduction. For example, in the schools, the contracts require recycling of packaging, compostable or washable dining service materials (cutlery, plates, glasses, etc.), and composting of food waste.

\subsection{Third-party purchasing relationships \& contracts}

The use of third-party food service vendors is common in institutions (i.e., Aramark, Sodexho, and Compass Group). These big national players have preferred vendors and authorized vendors. Preferred vendors include national broad-line distributors from whom the purchasing agent is required to purchase the majority of their food according to incentivized contracts between those two parties. For example, Aramark has several national brands whom they partner with known as super distributors. Here, purchasing managers should purchase the majority of their products from these partners. The arrangements are fairly rigid and do not allow flexibility in purchasing off contract without getting an authorization from corporate headquarters.

From the purchasing respondent's perspective, these arrangements are an obstacle to sustainable purchasing. Often, purchasing people cannot get local or reduced packaging products from this arrangement. If the purchasing agent finds a sustainable product and wants a super distributor to carry that product, it is the agent's responsibility to find other institutions in the area that may want that product to build up sufficient demand. The private school and hospital, which formerly employed a third-party food service, terminated the relationship because it did not allow for creativity and customization. In this case, there are still numerous financial and convenience incentives in place for the purchasing agents to deal directly with the large broad-line distributor for most of their food products. But, the purchasing agents feel they have more control in purchasing the products they need. Additionally, the large distributors are reliable and have more ability to overcome obstacles relative to the smaller distributors.

Similarly, the group purchasing contracts used by hospitals act as a deterrent to customization and creativity. All hospital respondents were part of group purchasing organizations (three or more hospital groups purchasing together for economies of scale). Initially, sustainability issues such as purchasing locally or packaging reduction were not on their radar, but now these kinds of issues are an expectation from their vendors. In these arrangements, one vendor is selected for the majority of purchases, but the purchasing person can chose local vendors for milk, bread, and fresh produce.

According to all respondents, the large broad-line distributors were originally resistant to responding to these sustainability issues. But they have shifted their attitude to be more responsive as the sustainability movement grows across the country. Some of this responsiveness also comes from organizations with big purchasing powers such as hospital groups and large private universities. 


\subsubsection{Outcomes}

The outcome topics cover what organizations have been able to do to reduce transportation distances traveled (local purchasing efforts), food waste and packaging waste. Overall, most institutions felt that food service contracts or policies that had goals and reporting requirements about local purchasing and waste reduction were the most effective tools for addressing these issues. These overarching policies then led the food service provider to change their contracts with waste management companies. In this case, the waste management companies had to provide more compost bins and less overall dumpster capacity. This change has freed up space on the loading docks and changed how the loading dock operates.

Composting poses certain challenges since certain states do not allow institutional composting and it can attract pests. Many of the institutions have added pulping systems to reduce waste and create compost. All are trying to recycle and reuse what they can of packaging materials. Food waste reduction was accomplished by buying less perishable food, cooking smaller portions or cooking on demand, and donating excess food to shelters.

Efforts to buy more local food products have led kitchens to change entire recipes to incorporate seasonal foods from their area rather than just substituting products. This type of menu flexibility is possible in places with kitchen flexibility such as scratch kitchens, but not limited-preparation kitchens. The universities felt that they could make a cheaper and higher quality salad product in their own kitchen rather than purchasing pre-made salads from a value-add producer. Buying local seasonal foods does reduce customer choices, so the message must be conveyed to the customer. And menu flexibility is limited in hospitals, which have constrained diets.

The biggest packaging waste comes from grocery products, particularly tomato-based products such as processed tomatoes, tomato sauce, and ketchup. This example was brought up by almost all respondents. Typically, they are purchased in cases of six \#10 cans, resulting in both cardboard and steel can waste. While both can be recycled, they are still contributors to the waste stream. A potential solution is to purchase this type of grocery product in bag-in-box packaging. The other products that have this packaging option are salad dressings, milk, and other sauces. Bulk packaging is very important to schools for cost reduction; individual-portion packaging is more common for hospitals due to sanitation, smell, logistics, and processing concerns. Both institution types are conscious of their packaging and try to move away from excessive plastic packaging, such as switching from chicken breasts in plastic trays to 10-pound bulk packs.

\subsubsection{Highest-volume food products}

Respondents indicated that meat was the highest-volume item, particularly chicken. The chicken packaging that generated the most waste was frozen chicken breasts in tray packs. Each chicken breast has a slot in a formed plastic tray, holding eight breasts, wrapped in plastic poly bags and delivered in cardboard boxes holding 48 breasts. The broad-line vendor product came from Tyson Chicken. The alternative packaging was the 
bulk pack, which includes 10 pounds of chicken in a plastic poly bag, with four bags to a cardboard box. The local vendor for fresh chicken is Foster Farms or Draper Valley (for Portland).

The second highest-volume item for packaging waste was canned tomato products in \#10 steel cans. Six cans come in each box. As an alternative, all the tomato products could be purchased in bag-in-box treatments except for whole processed tomatoes, which cannot fit through the nozzle on the package.

The highest-volume produce item for all institutional vendors was potatoes. Most fresh, non-value-added produce has similar packaging: either a plain, cardboard box for dry product or a waxed box for produce that should be kept moist.

\subsection{INTERVIEW CONCLUSIONS}

From the above results, first, it is clear that any efforts related to purchasing food products from closer locations (i.e., local food) and waste reduction efforts must happen in a cost-effective way. Thus, packaging improvements, processing type, and transportation method should contribute to food waste reduction to address the needs of the institutional purchasing group's drivers and focus.

Second, while these respondents contributed their ideas on the highest-volume food purchases and waste generators, it would be helpful to get a larger sample of perceptions of these two groups prior to determining the experimental design for comparing the greenhouse gas emissions of different choices.

Third, these initial interviews revealed key institution and supply chain structures that potentially contribute to the feasibility of changes to existing purchasing practices. These issues are of particular interest to both the academic and practitioner community. Thus, the team decided that further exploration of these issues, in addition to the appropriate greenhouse gas emission food and packaging criteria, were relevant for the survey phases. In particular, the alignment of the institution's policies with the rest of the triad (third-party food service and dominant distributor) would appear to affect the practices adopted by the institution and resulting increases in local food purchasing and reductions of waste streams. Additionally, the flexibility of the institution's contracts and food preparation facility would appear to affect the purchasing practices.

\subsection{PILOT SURVEY}

\subsubsection{Pilot survey methodology}

A pilot survey instrument was developed to collect data on industrial purchasing behavior regarding packaging and waste, food miles, and other sustainable purchasing issues. The survey instrument is summarized in Appendix A-2.

Participants were recruited through two industry organizations, American Society for Healthcare Food Service Administrators (ASHFSA) and National Association of College \& University Food Services (NACUFS). 
Email invitation was sent on July 30, 2008, to 900 people (ASHFSA), with a follow-up reminder on August 11, 2008, and 618 people (NACUFS) on August 25, 2008. Out of 33 who accessed the survey, 26 completed the entire survey, giving a response rate of $2 \%$. The last survey was completed on September 12, 2008. As compensation for participation, survey participants who completed the survey were given a \$5 Amazon.com gift certificate.

\subsubsection{Pilot survey demographics}

There were 26 completed surveys. Most of respondents (17, confirmed by email addresses) were from higher education institutions, while at least two were from health care institutions. The demographics of the respondents in terms of host firm size and structure of the buyer-supplier relationship are shown below.

\subsubsection{Size of organization}

Respondents reported the size of their organization in terms of the number of meals served per day, which varied from 120 to 25,000. Figure 2.1 shows how their responses were distributed.

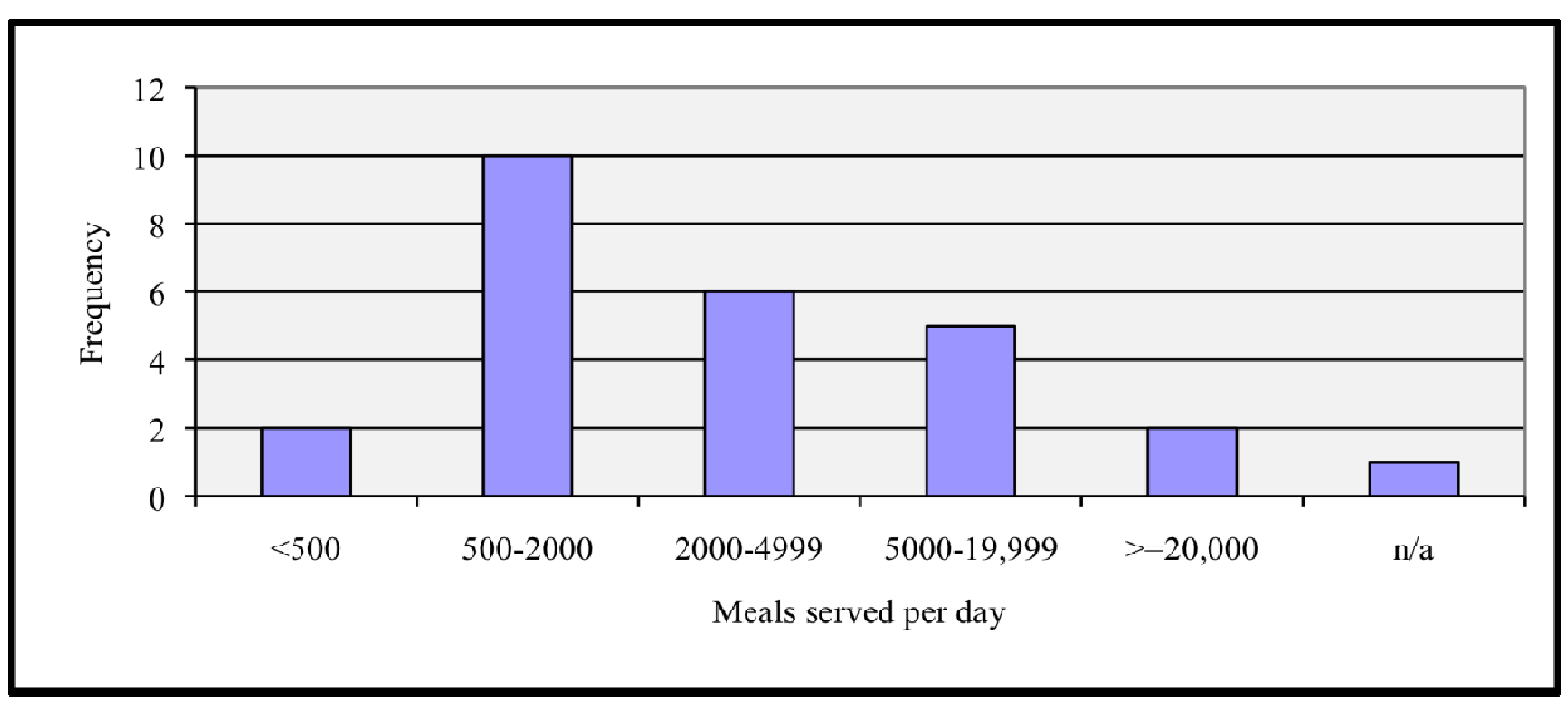

Figure 2.1 Size of respondent's firm, \# of meals served per day $(\mathrm{N}=26)$

\subsubsection{Buyer-supplier relationship}

Respondents were asked to characterize the structure of the buyer-supplier relationship that best describes their purchasing situation. Figure 2.2 shows the distribution of responses. Nearly all respondents were direct employees of the host organization, and they were split 50/50 between public and private organizations. 


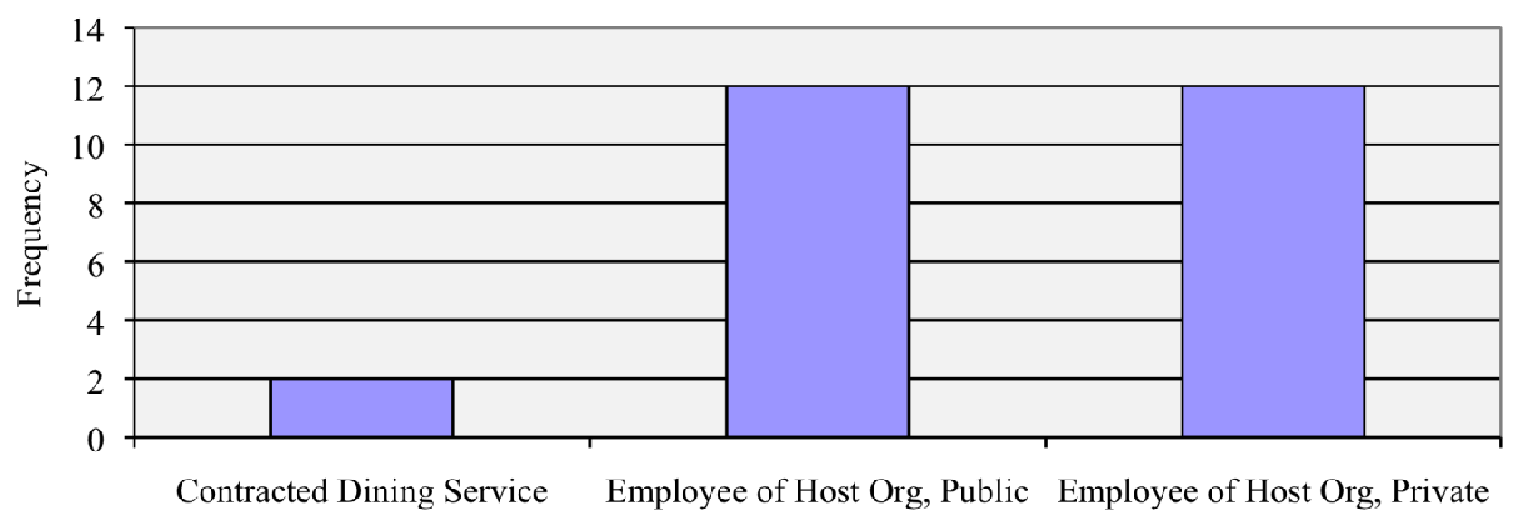

Type of Buyer-Organization Relationship

Figure 2.2 Buyer-supplier relationship ( $\mathrm{N}=26)$

\subsubsection{Pilot survey findings}

\subsubsection{Participant's priorities in purchasing decisions, ranking seven possible priorities}

Participants were asked to rank seven purchasing priorities in order of importance, where a 1 meant most important and 7 meant least important. The priorities they were asked about were: Cost (total cost or competitive pricing); Overall Food quality; Addressing end customer's requests; Sustainability practices (purchasing from local producers, farm practices); Flexibility (menu mix or customization); Overall Food Safety; and Other (where the participant entered alternative text). These priorities came from the focus areas provided in the interviews. The mean, median, mode, and standard deviations results are shown in Table 2.1 below (a lower number indicates that more participants ranked the priority as important). 
Table 2.1 Summary of participant's ranking of priorities in purchasing decisions

\begin{tabular}{|c|c|c|c|c|c|c|c|c|}
\hline \multicolumn{9}{|c|}{$\begin{array}{l}\text { Participant's purchasing priorities ranked } \\
1=\text { most important to } 7=\text { least important }\end{array}$} \\
\hline & & Cost & $\begin{array}{l}\text { Overall } \\
\text { Quality }\end{array}$ & $\begin{array}{c}\text { End } \\
\text { customer } \\
\text { Requests }\end{array}$ & Sustainability & Flexibility & $\begin{array}{l}\text { Food } \\
\text { Safety }\end{array}$ & Other \\
\hline \multirow[t]{2}{*}{$\mathrm{N}$} & Valid & 26 & 26 & 26 & 26 & 26 & 26 & 26 \\
\hline & Missing & 0 & 0 & 0 & 0 & 0 & 0 & 0 \\
\hline \multicolumn{2}{|c|}{ Mean } & 2.9231 & 1.6923 & 3.2308 & 4.8077 & 4.8846 & 2.6923 & 6.0769 \\
\hline \multicolumn{2}{|c|}{ Median } & 3.0000 & 2.0000 & 3.5000 & 5.0000 & 5.0000 & 2.0000 & 7.0000 \\
\hline \multicolumn{2}{|c|}{ Mode } & 3.00 & 2.00 & $2.00^{\mathrm{a}}$ & 6.00 & 6.00 & 1.00 & 7.00 \\
\hline \multicolumn{2}{|c|}{$\begin{array}{l}\text { Std. } \\
\text { Deviation }\end{array}$} & 1.32433 & .67937 & 1.39449 & 1.32723 & 1.45126 & 1.71509 & 2.03810 \\
\hline
\end{tabular}

This can also be seen in the boxplot below:

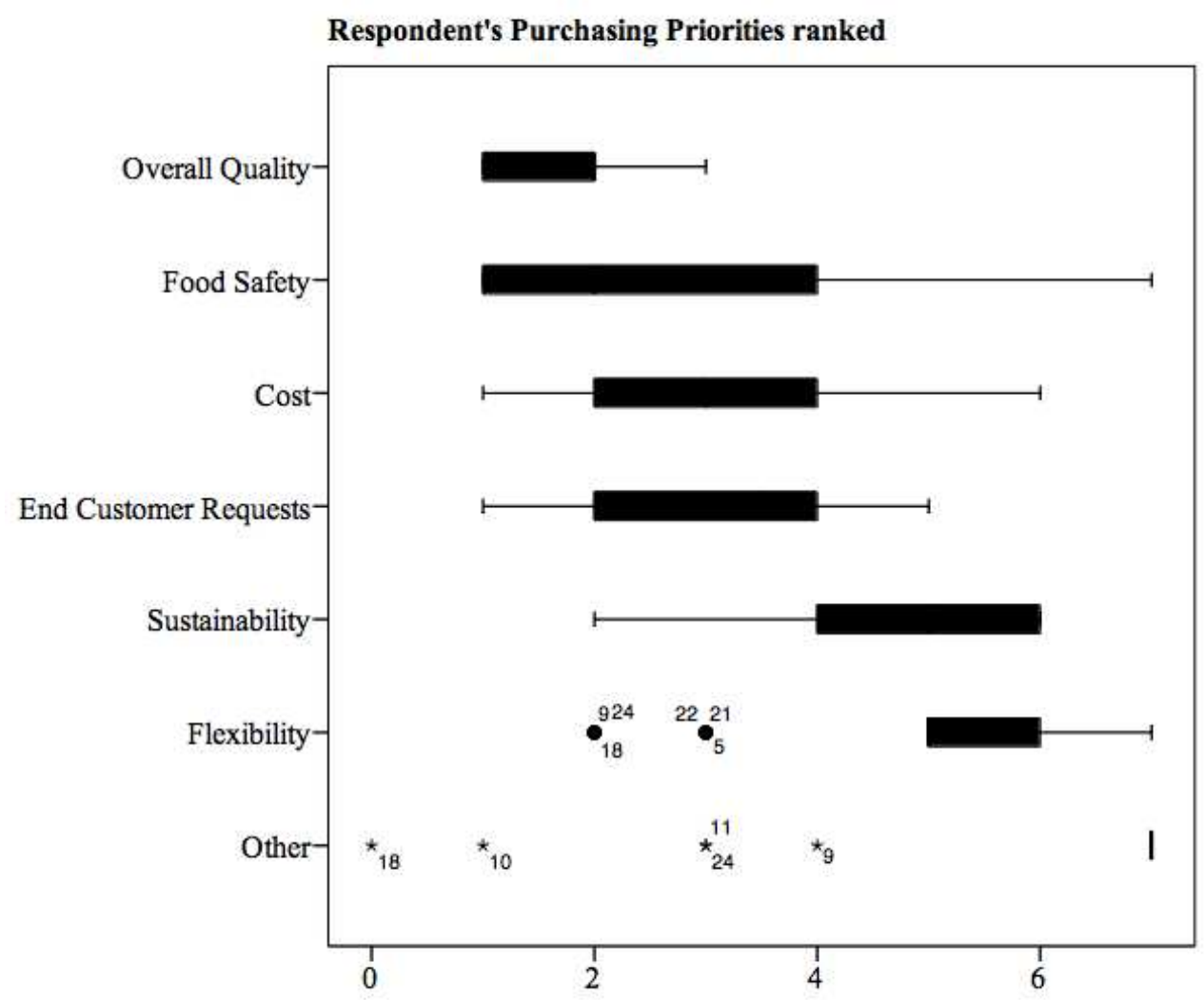

Figure 2.3 Summary of frequency of participant's ranking of priorities on purchasing decisions - Boxplot 
As shown in the boxplot and table above (Table 2.1), the participant's purchasing priorities were more focused on Overall Quality and Food Safety than Cost, End Customer Requests, Sustainability or Flexibility.

\subsubsection{Respondent's priorities in purchasing decisions within their particular purchasing environment}

Using a seven-point scale of agreement, where 1 means "strongly disagree" and 7 means "strongly agree," respondents were given four statements about purchasing priorities and were asked about their agreement with each of these statements for either their end customer group or their purchasing organization. The statements were as follows:

Please indicate your level of agreement with the following statements regarding purchasing practices: [My Food Purchasing Organization] or [My End Customer]...

- is fully committed to sustainable purchasing practices. (Sustainable Purchasing)

- encourages purchases of local products whenever possible. (Local Purchasing)

- sees packaging waste reduction as an important goal. (Packaging Waste Reduction)

- sees food waste reduction as an important goal. (Food Waste Reduction)

Table 2.2 Summary of respondent's priorities in purchasing decisions, from understanding of food purchasing organization

Perceived Priorities of Food Purchasing Organization 1=Strongly Disagree to $7=$ Strongly Agree

\begin{tabular}{|c|c|c|c|c|c|}
\hline & $\begin{array}{l}\text { Sustainable } \\
\text { Purchasing }\end{array}$ & $\begin{array}{c}\text { Local } \\
\text { Purchasing }\end{array}$ & $\begin{array}{l}\text { Packaging } \\
\text { Waste } \\
\text { Reduction }\end{array}$ & $\begin{array}{c}\text { Food } \\
\text { Waste } \\
\text { Reduction }\end{array}$ \\
\hline \multirow[t]{2}{*}{$\mathrm{N}$} & Valid & 26 & 26 & 26 & 26 \\
\hline & Missing & 0 & 0 & 0 & 0 \\
\hline \multicolumn{2}{|c|}{ Mean } & 4.12 & 4.62 & 4.85 & 5.35 \\
\hline \multicolumn{2}{|c|}{ Median } & 4.00 & 5.00 & 5.00 & 5.50 \\
\hline \multicolumn{2}{|c|}{ Mode } & 5 & 7 & 5 & 7 \\
\hline \multicolumn{2}{|c|}{ Std. Deviation } & 1.633 & 2.002 & 1.782 & 1.719 \\
\hline
\end{tabular}

Respondents agreed most that their food purchasing organization was committed to sustainable purchasing, followed by agreeing a little less that their food purchasing organization encouraged purchases of local products. Respondents agreed even less that their food purchasing organization sees packaging waste reduction as an important goal. The respondents overall did not agree as much that their food purchasing organization saw food waste reduction as an important goal. Table 2.3 below shows the respondent's perceptions about their end customer regarding the four statements. 
Table 2.3 Summary of respondent's perceived end customer priorities

Perceived Priorities of End customer $1=$ Strongly Disagree to $7=$ Strongly Agree

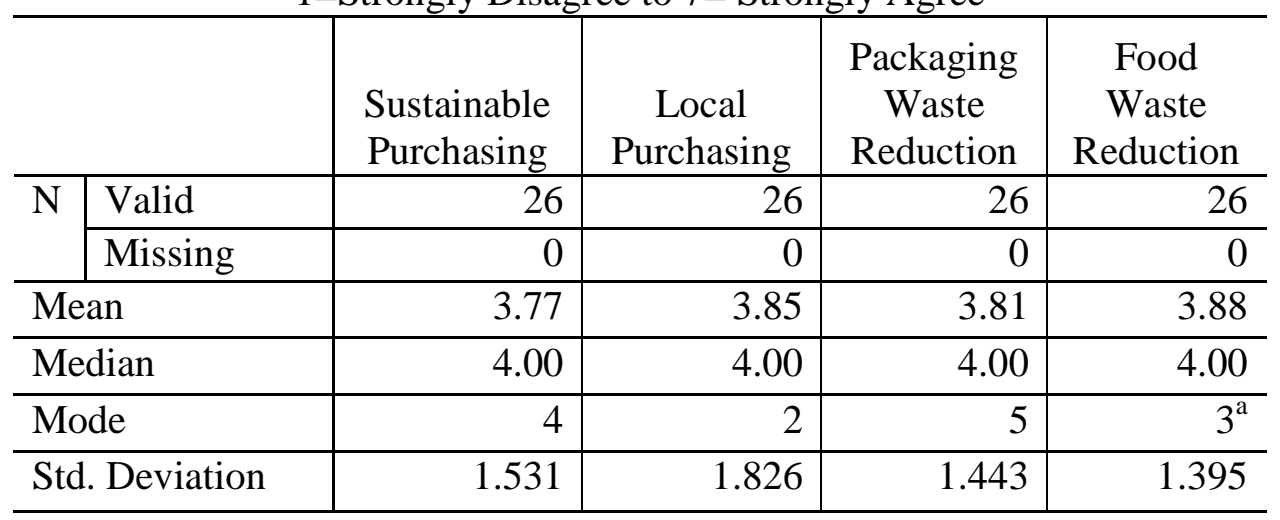

a. Multiple modes exist. The smallest value is shown

Respondents agreed most that their end customer was committed to sustainable purchasing, followed by agreeing a little less that their end customer sees packaging waste reduction as an important goal. Repondents agreed even less that their end customer encouraged purchases of local products. The respondents overall did not agree as much that their end customer saw food waste reduction as an important goal. The trend for end customer regarding packaging waste reduction and local purchasing is opposite the trend for the food purchasing organization; respondents agreed more that their food purchasing organization saw food waste reduction as an important goal compared to packaging waste reduction. They agreed less that their food purchasing organization encouraged purchases of local products. 
Table 2.4 t-test of respondent's perceived priorities of their food purchasing organization compared to their end customer

\begin{tabular}{|c|c|c|c|c|c|c|c|c|}
\hline \multicolumn{9}{|c|}{$\begin{array}{c}\text { Participant's perceived priorities: } \\
\text { Comparing Food Purchasing Organization and End Customer } \\
\text { Paired t-test }\end{array}$} \\
\hline & & Mean & $\mathrm{N}$ & $\begin{array}{c}\text { Std. } \\
\text { Deviation }\end{array}$ & $\begin{array}{l}\text { Std. } \\
\text { Error } \\
\text { Mean }\end{array}$ & $\mathrm{t}$ & Correlation & Sig. \\
\hline \multirow{2}{*}{$\begin{array}{l}\text { Sustainable } \\
\text { Purchasing }\end{array}$} & $\begin{array}{l}\text { Food } \\
\text { Purchasing } \\
\text { Organization }\end{array}$ & 4.12 & 26 & 1.633 & .320 & \multirow[t]{2}{*}{1.397} & \multirow[t]{2}{*}{.683} & \multirow[t]{2}{*}{.000} \\
\hline & $\begin{array}{l}\text { End } \\
\text { Customer }\end{array}$ & 3.77 & 26 & 1.531 & .300 & & & \\
\hline \multirow{2}{*}{$\begin{array}{l}\text { Local } \\
\text { Purchasing }\end{array}$} & $\begin{array}{l}\text { Food } \\
\text { Purchasing } \\
\text { Organization }\end{array}$ & 4.62 & 26 & 2.002 & .393 & \multirow[t]{2}{*}{2.936} & \multirow[t]{2}{*}{.760} & \multirow[t]{2}{*}{.000} \\
\hline & \begin{tabular}{|l|} 
End \\
Customer \\
\end{tabular} & 3.85 & 26 & 1.826 & .358 & & & \\
\hline \multirow{2}{*}{$\begin{array}{l}\text { Packaging } \\
\text { Waste } \\
\text { Reduction }\end{array}$} & $\begin{array}{l}\text { Food } \\
\text { Purchasing } \\
\text { Organization }\end{array}$ & 4.85 & 26 & 1.782 & .349 & \multirow[t]{2}{*}{3.391} & \multirow[t]{2}{*}{.548} & \multirow[t]{2}{*}{.004} \\
\hline & $\begin{array}{l}\text { End } \\
\text { Customer }\end{array}$ & 3.81 & 26 & 1.443 & .283 & & & \\
\hline \multirow{2}{*}{$\begin{array}{l}\text { Food Waste } \\
\text { Reduction }\end{array}$} & $\begin{array}{l}\text { Food } \\
\text { Purchasing } \\
\text { Organization }\end{array}$ & 5.35 & 26 & 1.719 & .337 & \multirow[t]{2}{*}{4.715} & \multirow[t]{2}{*}{.501} & \multirow[t]{2}{*}{.009} \\
\hline & \begin{tabular}{|l|} 
End \\
Customer
\end{tabular} & 3.88 & 26 & 1.395 & .274 & & & \\
\hline
\end{tabular}

A paired-sample t-test was conducted to evaluate whether the participant's level of agreement on the four statements about their perceptions were different between their end customer and their food purchasing organization. The results indicated that the mean scores for perceived commitment to all four topics, sustainable purchasing, local purchasing, packaging waste reduction, and food waste reduction were all significantly different between the participant's perceptions of their end customer and their food purchasing organization, where in all cases the food purchasing organization was perceived to have higher commitment than the end customer in all four topics.

There were also two participants who answered additional questions, designed for participants who were employees of contracted dining services. The results are not included because of the very small sample size.

\subsubsection{Buyer-supplier relationship}

In many institutional purchasing situations, purchasers have contracts with their supplier that significantly limits the amount and volume of items they can purchase from other suppliers. This 
survey asked a series of questions to explore this topic, including questions on membership in group purchasing organizations, diversity of suppliers, discretion over suppliers, and diversity in types of suppliers.

Group purchasing organizations are entities that individual purchasers can join to achieve greater buying power by negotiating contracts with suppliers as a group. In this survey, when asked if they were part of a group purchasing organization, all participants answered that they were not. When asked about the diversity of their suppliers (number of vendors they usually purchase from), $35 \%$ of participants had between two and five vendors; $35 \%$ had between six and 10 vendors; $12 \%$ had 11 to 20 vendors; and $20 \%$ had more than 20 vendors (percentages were rounded up).

When respondents were asked how much discretion they had regarding the choice of suppliers, $4 \%$ said that they had no discretion over supplier selection; $39 \%$ reported that a majority of purchases were required to be from one or two suppliers with limited discretion over categories like diary or produce; $8 \%$ reported that at least half of purchases were required to be from one or two suppliers with full discretion over categories like diary or produce; and 50\% reported that they had full discretion to purchase from any supplier.

When respondents were asked about the percentage they purchased from different types of suppliers (national supplier, local produce supplier, local dairy supplier, local meat supplier, individual supplier, or other), the highest mean percentage was from a national supplier, while the lowest mean percentage was from an individual supplier. All types of suppliers mean percentages are shown in Table 2.5.

Table 2.5 Respondent's mean percentages of purchases from different types of suppliers

\begin{tabular}{l|r|r|r|r|r}
\hline \multicolumn{7}{c}{ Characteristics of Suppliers } \\
\hline & $\mathrm{N}$ & \multicolumn{1}{c}{ Minimum } & \multicolumn{1}{c}{ Maximum } & \multicolumn{1}{c}{ Mean } & Std. Deviation \\
\hline National & 26 & $0.00 \%$ & $100.00 \%$ & $65.15 \%$ & $26.46 \%$ \\
\hline $\begin{array}{l}\text { Local } \\
\text { produce }\end{array}$ & 26 & $0.00 \%$ & $40.00 \%$ & $11.46 \%$ & $10.08 \%$ \\
\hline $\begin{array}{l}\text { Local } \\
\text { dairy }\end{array}$ & 26 & $0.00 \%$ & $25.00 \%$ & $8.42 \%$ & $8.17 \%$ \\
\hline Local meat & 26 & $0.00 \%$ & $25.00 \%$ & $7.31 \%$ & $7.06 \%$ \\
\hline Other & 26 & $0.00 \%$ & $65.00 \%$ & $5.65 \%$ & $14.08 \%$ \\
\hline Individual & 26 & $0.00 \%$ & $15.00 \%$ & $2.00 \%$ & $3.73 \%$ \\
\hline $\begin{array}{l}\text { Valid N } \\
\text { (listwise) }\end{array}$ & 26 & & & & \\
\hline
\end{tabular}




\subsubsection{Obstacles to adopting different purchasing practices}

Respondents were asked to rate the extent to which various issues were obstacles to adopting sustainable food purchasing practices (on a five-point scale where 1 was "very serious" and 5 was "no problem at all"). The issues were (Rábade and Alfaro 2006):

- Seasonal variation in food supply

- Perishability of sustainable food items

- Limited breadth of product line

- Lack of sustainable suppliers

- Lack of competition among sustainable suppliers

- Lack of infrastructure for sustainable suppliers

- Increased liability for food safety

- Lack of trust, safety or confidence in suppliers of those products

- Lack of supplier information on farming and processing characteristics (including origin)

Table 2.6 Comparing means of extent to which issue is obstacle to adopting sustainable food purchasing

Obstacles to adopting sustainable food purchasing $1=$ very serious to $5=$ no problem at all

\begin{tabular}{|c|c|c|c|c|c|c|}
\hline & \multicolumn{2}{|r|}{$\mathrm{N}$} & \multirow[b]{2}{*}{ Mean } & \multirow[b]{2}{*}{ Median } & \multirow[b]{2}{*}{ Mode } & \multirow{2}{*}{$\begin{array}{c}\text { Std. } \\
\text { Deviation }\end{array}$} \\
\hline & Valid & Missing & & & & \\
\hline Seasonal variation & 26 & 0 & 2.31 & 2.00 & 2 & 1.320 \\
\hline Perishability of sustainable items & 26 & 0 & 2.85 & 2.50 & 2 & 1.488 \\
\hline Limited breadth of product line & 26 & 0 & 2.19 & 2.00 & 2 & 1.096 \\
\hline Lack of sustainable supplier & 26 & 0 & 2.04 & 2.00 & $1^{\mathrm{a}}$ & 1.183 \\
\hline $\begin{array}{l}\text { Lack of competition among } \\
\text { sustainable suppliers }\end{array}$ & 26 & 0 & 2.62 & 3.00 & 3 & 1.169 \\
\hline $\begin{array}{l}\text { Lack of infrastructure for } \\
\text { sustainable suppliers }\end{array}$ & 26 & 0 & 1.81 & 2.00 & $1^{\mathrm{a}}$ & .939 \\
\hline Increased liability of food safety & 26 & 0 & 2.65 & 3.00 & 1 & 1.325 \\
\hline $\begin{array}{l}\text { Lack of trust, safety or } \\
\text { confidence in suppliers of those } \\
\text { products }\end{array}$ & 26 & 0 & 3.04 & 3.00 & 3 & 1.076 \\
\hline $\begin{array}{l}\text { Lack of supplier info on farming } \\
\text { and processing characteristics }\end{array}$ & 26 & 0 & 2.38 & 2.00 & 2 & 1.134 \\
\hline
\end{tabular}

a. Multiple modes exist. The smallest value is shown

Overall, respondents listed "lack of infrastructure for sustainable suppliers" as the most serious obstacle to adopting sustainable food purchasing, with "lack of sustainable supplier" and "limited breath of product line" as the next most serious obstacles. "Seasonal variation" and 
"lack of supplier info on farming and processing characteristics" were listed as a little less serious; "lack of competition among sustainable suppliers" and "increased liability of food safety" were listed as even less serious; and "perishability of sustainable items" and "lack of trust, safety, or confidence in suppliers of those products" were listed as the least serious of all the obstacles.

Respondents were asked to rate the extent to which various issues were obstacles to reducing food packaging waste (on a five-point scale where 1 was "very serious" and 5 was "no problem at all"). The issues were (Min and Galle 2001):

- High cost of waste reduction programs

- Uneconomic recycling of packaging

- Uneconomic reusing of packaging

- Lack of management commitment to waste reduction

- Lack of buyer awareness of waste impacts

- Lack of supplier awareness of waste impacts

- Lack of company-wide waste reduction standards or policies

- Loose city or state waste management regulations

- Loose federal waste management regulations 
Table 2.7 Comparing means of extent to which issue is obstacle to reducing food packing waste

\begin{tabular}{|c|c|c|c|c|c|c|}
\hline \multicolumn{7}{|c|}{$\begin{array}{c}\text { Obstacles to reducing food packaging waste } \\
1=\text { very serious to } 5=\text { no problem at all }\end{array}$} \\
\hline & \multicolumn{2}{|c|}{$\mathrm{N}$} & \multirow[b]{2}{*}{ Mean } & \multirow[b]{2}{*}{ Median } & \multirow[b]{2}{*}{ Mode } & \multirow{2}{*}{$\begin{array}{c}\text { Std. } \\
\text { Deviation }\end{array}$} \\
\hline & Valid & Missing & & & & \\
\hline $\begin{array}{l}\text { High cost of waste reduction } \\
\text { programs }\end{array}$ & 26 & 0 & 2.65 & 2.00 & 2 & 1.198 \\
\hline $\begin{array}{l}\text { Uneconomic recycling of } \\
\text { packaging }\end{array}$ & 26 & 0 & 2.65 & 2.00 & 2 & 1.198 \\
\hline $\begin{array}{l}\text { Uneconomic reusing of } \\
\text { packaging }\end{array}$ & 26 & 0 & 2.58 & 2.50 & 2 & .987 \\
\hline $\begin{array}{l}\text { Lack of management } \\
\text { commitment to waste } \\
\text { reduction }\end{array}$ & 26 & 0 & 3.23 & 3.00 & 3 & 1.177 \\
\hline $\begin{array}{l}\text { Lack of buyer awareness of } \\
\text { waste impacts }\end{array}$ & 26 & 0 & 2.92 & 2.50 & 2 & 1.197 \\
\hline $\begin{array}{l}\text { Lack of supplier awareness } \\
\text { of waste impacts }\end{array}$ & 26 & 0 & 2.88 & 3.00 & 3 & 1.177 \\
\hline $\begin{array}{l}\text { Lack of company-wide } \\
\text { waste reduction standards or } \\
\text { policies }\end{array}$ & 26 & 0 & 2.92 & 3.00 & 2 & 1.324 \\
\hline $\begin{array}{l}\text { Loose city or state waste } \\
\text { management regulations }\end{array}$ & 26 & 0 & 2.85 & 3.00 & 3 & 1.120 \\
\hline $\begin{array}{l}\text { Loose federal waste } \\
\text { management regulations }\end{array}$ & 26 & 0 & 2.69 & 3.00 & 3 & 1.087 \\
\hline
\end{tabular}

Overall, respondents listed "uneconomic reusing of packaging" as the most serious obstacle to reducing food packaging waste, with "high cost of waste reduction programs," "uneconomic recycling of packaging," and "loose federal waste management regulations" as the next most serious obstacles. "Loose city or state waste management regulations," "lack of supplier awareness of waste impacts," "lack of buyer awareness of waste impacts," and "lack of company-wide waste reduction standards or policies" were listed as a little less serious. "Lack of management commitment to waste reduction" was listed as the least serious of all the obstacles.

\subsubsection{Purchasing processed foods and on-site facilities for processing}

Respondents were asked what percentages of their purchased food were various types of processed food. The types of processed food were:

- Raw materials for scratch cooking and baking

- Pre-processed baking mixes and sauces

- Pre-chopped or shredded food items

- Pre-made and frozen bulk menu items (lasagna, cakes, etc.)

- Pre-made individual menu items (entrees, salads, etc.) 
- Other

Table 2.8 Percentages of purchases that are processed food, by type of processed food

\begin{tabular}{l|r|r|r|r|r|r}
\hline \multicolumn{4}{c}{ Mean percentages of food purchases in terms of types of processed foods } \\
\cline { 2 - 7 } & \multicolumn{2}{|c|}{$\mathrm{N}$} & & & & \\
\cline { 2 - 6 } & Valid & Missing & Mean & Median & Mode & Std. Deviation \\
\hline $\begin{array}{l}\text { Raw materials for scratch } \\
\text { cooking and baking }\end{array}$ & 26 & 0 & $49.92 \%$ & $50.00 \%$ & $50.00 \%$ & $26.84 \%$ \\
\hline $\begin{array}{l}\text { Pre-processed baking } \\
\text { mixes and sauces }\end{array}$ & 26 & 0 & $14.27 \%$ & $10.00 \%$ & $10.00 \%$ & $9.29 \%$ \\
\hline $\begin{array}{l}\text { Pre-chopped or shredded } \\
\text { food items }\end{array}$ & 26 & 0 & $11.92 \%$ & $10.00 \%$ & $5.00 \%$ & $11.20 \%$ \\
\hline $\begin{array}{l}\text { Pre-made and frozen bulk } \\
\text { menu items }\end{array}$ & 26 & 0 & $13.58 \%$ & $10.00 \%$ & $0.00 \%$ & $14.44 \%$ \\
\hline $\begin{array}{l}\text { Pre-made individual menu } \\
\text { items }\end{array}$ & 26 & 0 & $6.85 \%$ & $5.00 \%$ & $0.00 \%$ & $8.79 \%$ \\
\hline Other & 26 & 0 & $3.46 \%$ & $0.00 \%$ & $0.00 \%$ & $7.45 \%$ \\
\hline
\end{tabular}

a. Multiple modes exist. The smallest value is shown

Raw materials for scratch cooking and baking was by far the highest average percentage of categories of levels of processed foods at almost 50\%, while pre-processed baking mixes and sauces, pre-chopped or shredded food items, and pre-made and frozen bulk menu items were all roughly equal, between $12-14 \%$ of total food purchased. Pre-made individual menu items were the lowest average percent of total food purchased, at $7 \%$.

When respondents were asked to describe their level of food preparation facilities, $44 \%$ had a full bakery and kitchen; $41 \%$ had a full kitchen and simple bakery (cookies, cakes, etc); and 15\% had a full kitchen that could do simple food prep (chopping, mixing) and baking. No respondents had either a kitchen with limited food prep and bakery or a facility without food prep or mixing.

\subsubsection{Food purchased with sustainable characteristics}

When asked what percentage of their total food purchases were locally grown and produced (within 150 miles of the respondent's institution), the average was 13\%, while the range of answers was $0-40 \%$ and the standard deviation was $11.76 \%$. The average percentage of total food purchases that were third-party certified food or beverage products (Fair Trade, Food Alliance, Organic, Salmon-Safe, etc.), was $8 \%$, the range was $0-50 \%$ and the standard deviation was $10.43 \%$.

\subsubsection{Assessing packaging and food waste reduction programs for 10 different types of packaging or food waste, and percent reduced if program is implemented}

Respondents were asked about the status of their programs for recycling five types of packaging materials. For each type of packaging they could choose one of four options: Implemented, In- 
process, Considering, and Not Considering. The results of the survey regarding the recycling of packaging are summarized in Table 2.9.

Table 2.9 Packaging recycling results ( $N=26$ Overall)

\begin{tabular}{l|l|l|l|r|r|c}
\hline & $\begin{array}{l}\text { \% of } \\
\text { Respondents } \\
\text { Who have } \\
\text { Implemented } \\
\text { Recycling }\end{array}$ & $\begin{array}{l}\text { \% Who } \\
\text { are In- } \\
\text { Process }\end{array}$ & $\begin{array}{l}\% \text { Who are } \\
\text { Considering }\end{array}$ & $\begin{array}{l}\text { \% Not } \\
\text { Considering }\end{array}$ & $\begin{array}{l}\text { Recycled } \\
\text { by Those } \\
\text { Who } \\
\text { Recycle }\end{array}$ & $\begin{array}{c}\text { N for \% } \\
\text { Recycled }\end{array}$ \\
\hline $\begin{array}{l}\text { Cardboard } \\
\text { and paper }\end{array}$ & $86 \%$ & $7 \%$ & $0 \%$ & $7 \%$ & $98 \%$ & 17 \\
\hline Glass & $62 \%$ & $11 \%$ & $20 \%$ & $7 \%$ & $85 \%$ & 14 \\
\hline Metal/Can & $69 \%$ & $11 \%$ & $16 \%$ & $4 \%$ & $90 \%$ & 16 \\
\hline Hard Plastic & $59 \%$ & $7 \%$ & $27 \%$ & $7 \%$ & $80 \%$ & 11 \\
\hline Soft Plastic & $31 \%$ & $11 \%$ & $27 \%$ & $31 \%$ & $90 \%$ & 7 \\
\hline
\end{tabular}

Cardboard and paper was the packaging material that had the most implemented recycling program; $86 \%$ of respondents had implemented a recycling program. Within the recycling program for cardboard and paper, $98 \%$ of the packaging was being recycled. Seven percent $(7 \%)$ of respondents were in the process of implementing a program to recycle cardboard and paper, and $7 \%$ were not considering implementing a program.

Metal cans were the next highest packaging material in terms of implemented recycling programs, at $69 \%$ of respondents with a program. The average recycling percentage of respondents with programs implemented was $90 \%$ of all metal cans.

Glass and hard plastic had similar implementation rates, at $62 \%$ and $59 \%$, respectively. The average recycling percentage of respondents with programs implemented was $85 \%$ and $80 \%$ of all glass and hard plastic, respectively. The hard plastic recycling rate of $80 \%$ made it the lowest recycled of all the packaging materials.

Soft plastic was the packaging material with the lowest recycling program implementation at $31 \%$ of respondents. But in terms of actual recycling percentages, soft plastic - at $90 \%$ - was not the lowest of all packaging material.

Respondents were also asked about recycling of non-packaging material, reuse of packaging materials (e.g., plastic tubs, buckets, pallets) and food waste composting, as shown in Table 2.10. 
Table 2.10 Non-packaging recycling, reuse, and composting results ( $\mathrm{N}=26$ Overall)

\begin{tabular}{l|r|r|r|r|r|c}
\hline & $\begin{array}{l}\text { \% of } \\
\text { Respondents } \\
\text { Who have } \\
\text { Implemented }\end{array}$ & $\begin{array}{l}\text { Who In- } \\
\text { are In } \\
\text { Process }\end{array}$ & $\begin{array}{l}\text { \% Who are } \\
\text { Considering }\end{array}$ & $\begin{array}{l}\text { \% Not } \\
\text { Considering }\end{array}$ & $\begin{array}{l}\text { Recycled } \\
\text { by Those } \\
\text { Who } \\
\text { Recycle }\end{array}$ & $\begin{array}{c}\text { N for \% } \\
\text { Recycled }\end{array}$ \\
\begin{tabular}{l|r|r|r|r} 
Item \\
Recycling \\
paper \\
cups/plates
\end{tabular} & $11 \%$ & $15 \%$ & $30 \%$ & $44 \%$ & $97 \%$ & 3 \\
\hline $\begin{array}{l}\text { Recycling hard } \\
\text { plastic } \\
\text { cups/plates }\end{array}$ & $11 \%$ & $11 \%$ & $30 \%$ & $48 \%$ & $90 \%$ & 3 \\
\hline $\begin{array}{l}\text { Reuse of tubs, } \\
\text { buckets, pallets }\end{array}$ & $59 \%$ & $19 \%$ & $11 \%$ & $11 \%$ & $71 \%$ & 15 \\
\hline $\begin{array}{l}\text { Food } \\
\text { composting } \\
\text { onsite }\end{array}$ & $11 \%$ & $4 \%$ & $43 \%$ & $42 \%$ & $63 \%$ & 3 \\
\hline $\begin{array}{l}\text { Food } \\
\text { composting } \\
\text { offsite }\end{array}$ & $11 \%$ & $4 \%$ & $43 \%$ & $42 \%$ & $75 \%$ & 2 \\
\hline
\end{tabular}

As can be seen in Table 2.10, reuse is a current practice for over half of the respondents, and they are able to reuse a large fraction of the reusable items. The other items - recycling of paper and plastic cups and plates - and food composting represent a future opportunity for the most part.

\subsubsection{Product mix and packaging characteristics}

Respondents were asked to indicate their most purchased food product from each the following categories: Baked Goods, Dairy, Meat, Fruits, and Vegetables. They were also asked for the number of servings per purchased package, the volume purchased per year in pounds, and the type(s) of packaging utilized. The volumes reported varied widely, so outliers were eliminated using an ad hoc method, and a median value was estimated. The product mix and packaging characteristics are summarized in Table 2.11. 
Table 2.11 Most significant food items and their packaging characteristics $(\mathrm{N}=\mathbf{2 6})$

\begin{tabular}{l|l|l|l|l|c}
\hline Category & Biggest Item & Packaging Qty. & $\begin{array}{l}\text { Fresh/ } \\
\text { Frozen }\end{array}$ & \multicolumn{1}{|c}{ Packaging } & $\begin{array}{c}\text { Median lbs. per } \\
\text { meal per year }\end{array}$ \\
\hline Meat & Chicken & $>25$ svgs./pkg. & $\begin{array}{l}68 \% \\
\text { frozen }\end{array}$ & $\begin{array}{l}60 \% \text { paper/40\% } \\
\text { plastic }\end{array}$ & 10 \\
\hline Dairy & Milk & $>25$ svgs./pkg. & $\begin{array}{l}90 \% \\
\text { fresh }\end{array}$ & $\begin{array}{l}35 \% \text { paper/40\% } \\
\text { plastic jug/25\% } \\
\text { plastic bag }\end{array}$ & 5 \\
\hline Fruit & Bananas/Apples & $>25$ svgs./pkg. & $\begin{array}{l}97 \% \\
\text { fresh }\end{array}$ & $93 \%$ cardboard box & 3 \\
\hline Baked & Potatoes & $>25$ svgs./pkg. & $\begin{array}{l}73 \% \\
\text { fresh }\end{array}$ & $\begin{array}{l}60 \% \text { paper/40\% } \\
\text { plastic }\end{array}$ & 4 \\
\hline
\end{tabular}

By weighting the percentages of paper packaging shown in Table 2.11 by the annual number of pounds for each food item, the overall packaging percentage for paper can be estimated to represent 55\% of all institutional food packaging. By similar logic, hard plastic represents $8 \%$ and soft plastic $35 \%$. The other two are insignificant. Further, by multiplying these packaging percentages by the "\% who have implemented recycling" and the "\% recycled by those who recycle" (both in Table 2.9), one can estimate the current status of food packaging recycling, as shown in Table 2.12.

Table 2.12 Estimated current overall status of food packaging recycling

\begin{tabular}{l|l|l|l}
\hline & $\begin{array}{l}\text { Overall \% of } \\
\text { Institutional Food } \\
\text { Packaging }\end{array}$ & $\begin{array}{l}\text { lurrent } \\
\text { Contribution to } \\
\text { \% Recycled }\end{array}$ & $\begin{array}{l}\text { Future Contribution, } \\
\text { Those Implementing } \\
\text { and Considering }\end{array}$ \\
\hline Cardboard and paper & $55 \%$ & $46 \%$ & $4 \%$ \\
\hline Glass & $\mathrm{NS}$ & $\mathrm{NS}$ & $\mathrm{NS}$ \\
\hline Metal/Can & $\mathrm{NS}$ & $\mathrm{NS}$ & $2 \%$ \\
\hline Hard Plastic & $8 \%$ & $4 \%$ & $11 \%$ \\
\hline Soft Plastic & $35 \%$ & $3 \%$ & $17 \%$ \\
\hline & TOTAL & $53 \%$ & \\
\hline
\end{tabular}

Considering the figures in Table 2.12, one can see that today just over half of all institutional food packaging is being recycled. When those who are currently implementing or considering a packaging recycling program have completed their implementations, the recycling percentage can be anticipated to increase to $70 \%$ overall.

\subsubsection{Pilot survey discussion}

Sustainability was not a high priority when respondents were asked to rank their purchasing priorities, but respondents did believe that their food purchasing organizations and end customer were committed to sustainable purchasing. Respondents also indicated that, on average, they had a lot of discretion on their choice of supplier (50\% reported full discretion), and were not bound 
by group purchasing organization restrictions. Most respondents purchased the majority of their food from national suppliers (average of $65 \%$ of total food), and saw the most serious obstacle of adopting sustainable food purchasing to be lack of infrastructure for sustainable suppliers. On average, $13 \%$ of respondent's purchases were locally grown and produced, while third-party certified food or beverage products were only, on average, $8 \%$ of respondent's total food and beverage purchases.

When it came to packaging waste reduction, respondents saw uneconomic reusing of packaging as the most serious obstacle. Despite obstacles in reusing packaging, cardboard and paper, glass, metal cans, hard plastic, and soft plastic all had high recycling rates (above 75\%) with respondents who had recycling programs.

On average, almost half of the respondent's food is purchased as raw materials for scratch cooking and baking, although much of the food is purchased frozen. Chicken was reported as the most common meat purchased, and $68 \%$ of it was purchased frozen. Bread was reported as the most common baked good purchased, and $73 \%$ of it was purchased frozen. Other common foods such as milk, bananas/apples, and potatoes were mostly purchased fresh. Packaging information for these foods was collected to be used in the life-cycle analysis (See Section 4).

\subsection{PILOT SURVEY CONCLUSIONS}

Based on the pilot survey results, the high-volume foods and packaging alternatives for the lifecycle analysis were clearly important (see Section 4). However, to empirically test the emerging theory regarding alignment would require a larger sample size, and the pilot survey results showed that the final survey would need to be much shorter (see Section 3).

Given the low response rate in the pilot study, the survey was redesigned to shorten it for better response rate and to focus on fewer items, selected through analysis of pilot study results. The final survey did not include as many questions on specific food items, and instead focused on the influence of end customers, host organizations and third-party suppliers on the respondent's purchasing decisions regarding local and sustainable choices. 


\subsection{INSTITUTIONAL CONTEXT AND PRACTICES (FINAL) SURVEY}

Based on the findings of the interviews and pilot survey, it became clear that certain institutional context factors appeared to contribute to policies, practices, and performance outcomes related to purchasing choices. In particular, the influence of end customer, the host organization and, when relevant, the third-party food service provider could potentially create different outcomes for locally purchased food (reduced transportation miles) and waste reduction and recycling of food packaging. For this stage of the research, a theoretical model was developed and tested to explore these effects.

\subsection{BACKGROUND}

Rising concern about the environmental impact of food transportation has led many firms to define policies and implement practices that reduce their ecological footprint (Bauccio and Halwell 2005). The policies and practices account for a variety of activities of the product life cycle. In order to develop and manage systems that reduce ecological impact, food retail institutions must maintain collaborative relations with suppliers, transportation and logistics providers, and waste haulers (Piercy and Lane 2006). Tukker (2006) identifies food as one of the top three contributors to the environmental impact in society (the other two are mobility and home energy use). Food transportation, broadly viewed, is a major part of that impact. The centralization of supermarket buying, the globalization and consolidation of the food industry, and the increased usage of regional distribution centers have all contributed to the escalation of food transportation over the past 30 years (Finney 2006).

Pirog and colleagues published two articles that outlined the concept of "food miles" to contrast local and global food supply systems (Pirog 2004; Pirog and Benjamin 2005). Food miles can provide a relative indicator of the amount of energy or fuel used to transport from farm to store, with lower food miles signaling lower transportation fuel usage and cost. Lower food miles also often translate to lower greenhouse gas emissions. Although strong advocacy for local food sourcing existed long before these studies were published, the results of the studies significantly increased the interest in the ecological impacts of local versus global food supply chains.

An important component of the food supply chain is the intermediary food industry that provides, for example, food products to students and hospital patients. This sector requires frequent and lengthy trips by food growers and producers to hubs in a complex food distribution network that contributes significantly to global carbon dioxide emissions (Horrigan, Lawrence, and Walker 2002). Increasingly, these businesses are assessing the impact of their purchasing decisions on their carbon footprints (Min and Galle 2001). Carbon footprint is one way to describe or measure the carbon emissions from a specific organization or process. Purchasing decisions have complex implications for the environment based on the mode of transportation employed, the corresponding packaging used to transport the goods, and the resulting waste and disposal transportation. For example, a hospital may choose to support local farmers and 
purchase seasonal food products rather than purchasing from large national food suppliers whose products tend to be sourced from multiple producers around the globe. The local farmer may use a pickup truck to service multiple customers with minimal packaging and recyclable totes, whereas the distributor tends to use long- and short-haul trucking with protective packaging that generates more waste and requires additional transportation to haul the waste to landfills.

The objective of this phase of research is to examine the purchasing decisions made by the intermediary food industry, as represented by hospitals and upper-level educational institutions. The project has two parts: 1) conducting an assessment of the current food miles of business supply chains, including modes of transport and distance traveled; developing a strategy to measure progress toward reducing the total food miles traveled; and evaluating the overall impact of the transportation process; and 2) assessing the waste associated with the supply chains from a life-cycle perspective, with a specific focus on the relationship between transportation mode and packaging. This process was started by assessing the current conditions for these organizations, conducted life-cycle assessments of different types of packaging materials, and then identified alternatives means to meet packaging requirements (e.g., shelf stability) that feature reduced environmental impacts. In-depth interviews, a survey, and simulation modeling were then used to analyze the policies and practices of a national sample of subject institutions, including how they manage relationships for key products and with key service providers.

Ultimately, the results of this study may serve as the foundation for a broader assessment of an organization's carbon footprint, which would extend to other forms of energy usage,

transportation, and materials management. This would represent an enhancement to assessment methodologies based purely on food-miles, which assume that greenhouse gases emitted during food transport can be accurately estimated knowing only the distances travelled by the food. This work is intended to build upon and extend Pirog's (2004; Pirog and Benjamin 2005) work on food miles by 1) focusing on the policies and practices of institutional upper-level education and hospitals, and 2) expanding beyond a food-miles analysis to include packaging, waste hauling and landfill disposal.

\subsection{PROPOSED MODEL}

Given the results of the interviews and pilot survey, it is reasonable to hypothesize that the context, or environment, of the buyer's purchasing decisions impacts their practices and behavior, which in turn shapes the outcomes and results of the buyer's practices. This study looks at various elements in the buyer's environment (our independent variables or determinants), level of policy implementation around local food purchasing and waste reduction, and the resulting outcomes from those policies. As independent variables, the institution and its customer values may align or differ on various purchasing and waste reduction practices (Fawcett, Magnan, and McCarter 2008; Lamming, Caldwell, and Harrison 2004; Bartlett, Julien, and Baines 2007). Similarly, the third-party buyer and organization may have the same alignment issues (Lee, Kwon, and Severance 2007). These differing perspectives would affect both the development and implementation of policies along with the subsequent changes in local purchasing and waste reduction.

Two other areas put constraints on the purchasing decisions. First, facility flexibility or the ability to process a complete range of food products within the institution can limit what the 
institution can process in terms of raw foods or pre-prepared foods, thus impacting the ability to buy from local producers and the related packaging waste. Similarly, contract flexibility has been linked to sustainability practice implementation (Giannakis 2007). The resulting proposed model is shown in Figure 3.1.

\section{Independent Variables Dependent Variables}

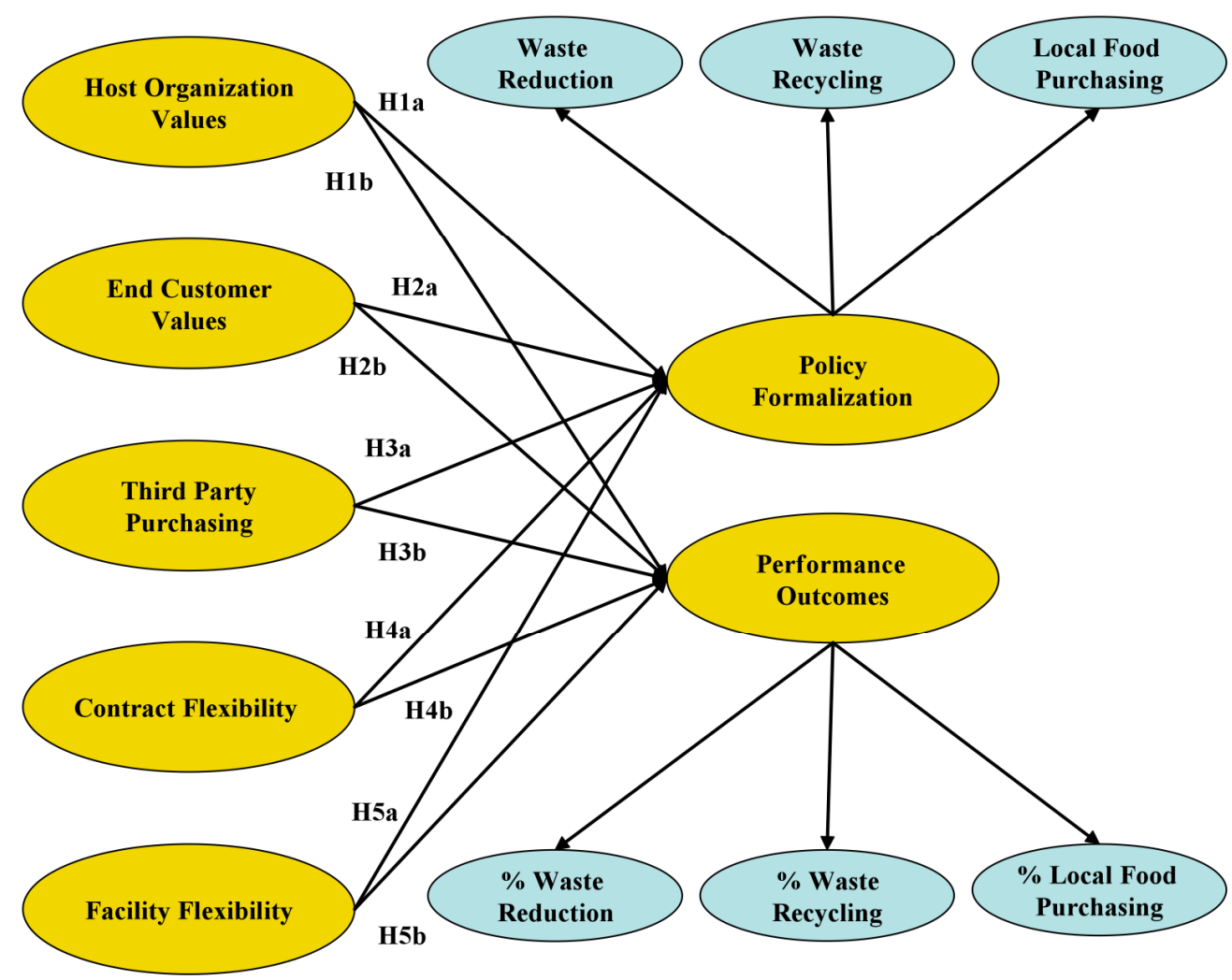

Figure 3.1 Proposed model

Associated with the above model, the following 10 hypotheses are proposed:

H1: The host organization's values related to sustainable purchasing, locally purchased foods, and packaging reduction is positively related to the:

a) formal level of policy in place related to waste reduction, waste recycling and local food purchasing,

b) percentage of waste reduced, recycled, and local food purchased.

H2: The end customer values related to sustainable purchasing, locally purchased foods, and packaging reduction is positively related to the:

a) formal level of policy in place related to waste reduction, waste recycling and local food purchasing, 
b) percentage of waste reduced, recycled, and local food purchased.

H3: Facility flexibility (kitchen has most scratch options) is positively related to level of sustainability practice implementation.

H4: The use of third-party purchasing is related to the:

a) formal level of policy in place related to waste reduction, waste recycling and local food purchasing,

b) percentage of waste reduced, recycled, and local food purchased.

H5: Level of contract flexibility is positively related to the:

a) formal level of policy in place related to waste reduction, waste recycling and local food purchasing,

b) percentage of waste reduced, recycled, and local food purchased.

H6: Level of kitchen and dining facility flexibility is positively related to the:

a) formal level of policy in place related to waste reduction, waste recycling and local food purchasing,

b) percentage of waste reduced, recycled, and local food purchased.

\subsection{FINAL SURVEY RESEARCH METHODOLOGY}

In this section, the research sample selection, survey data collection methodology and the survey are described.

\subsubsection{Final survey sample selection}

The hospital and university food purchasing organizations were selected because they are highvolume purchasers of food, and sustainability issues (local food purchasing and waste reduction) are very important concerns for these groups. Hospitals are particularly interested in the health and safety issues surrounding food and have an active sustainability interest group, Health Care without Harm, which has helped to support numerous organizational efforts to purchase more local food for freshness and reduce waste. Similarly, universities have a multiple stakeholders particularly student groups - with strong sustainability agendas.

\subsubsection{Final survey data collection methodology}

The final survey instrument was similar to the pilot survey, although it excluded many of the specific questions about types of food purchased and packaging for those foods. The survey instrument can be seen in Appendix A-3.

Respondents were recruited through two industry organizations, American Society for Healthcare Food Service Administrators (ASHFSA) and National Association of College \& University Food Services (NACUFS). The two industry organizations were approached to help secure an email of introduction and with the hope of encouraging a high response rate.

Email invitations were sent on December 12, 2008, to 900 people (ASHFSA) and 618 people (NACUFS). Out of 75 who accessed the survey, 68 completed the entire survey, giving a 
response rate of 5\%. The last survey was completed on January 23, 2009. As compensation for participation, survey respondents who completed the survey were given a \$10 Amazon.com gift certificate and the chance to win a $\$ 200$ donation to their local food charity.

\subsection{FINAL SURVEY RESULTS}

\subsubsection{Final survey demographic statistics}

The respondent group was 66, although in some cases four individuals did not answer all of the questions. These respondents were kept in the sample pool since pair-wise deletion was used for the model and wanted as many answers to be included as possible.

\subsubsection{Buyer-organization relationship}

Of the respondents, $23 \%$ indicated that the buyer-supplier relationship that best describes the purchasing situation at their facility was "contracted dining service." The remaining 77\% indicated that "employee of host organization" was the best description.

\subsubsection{Size of organization}

As with the pilot survey, the size of the organization was measured by the number of meals served per day. Rather than filling in a text field, in the final survey specific ranges were provided, as indicated in Figure 3.2. These ranges are similar to the ranges reported for the pilot survey, except that the lower range is separated to indicate very small operations, and the two upper categories reported earlier have been lumped into one category.

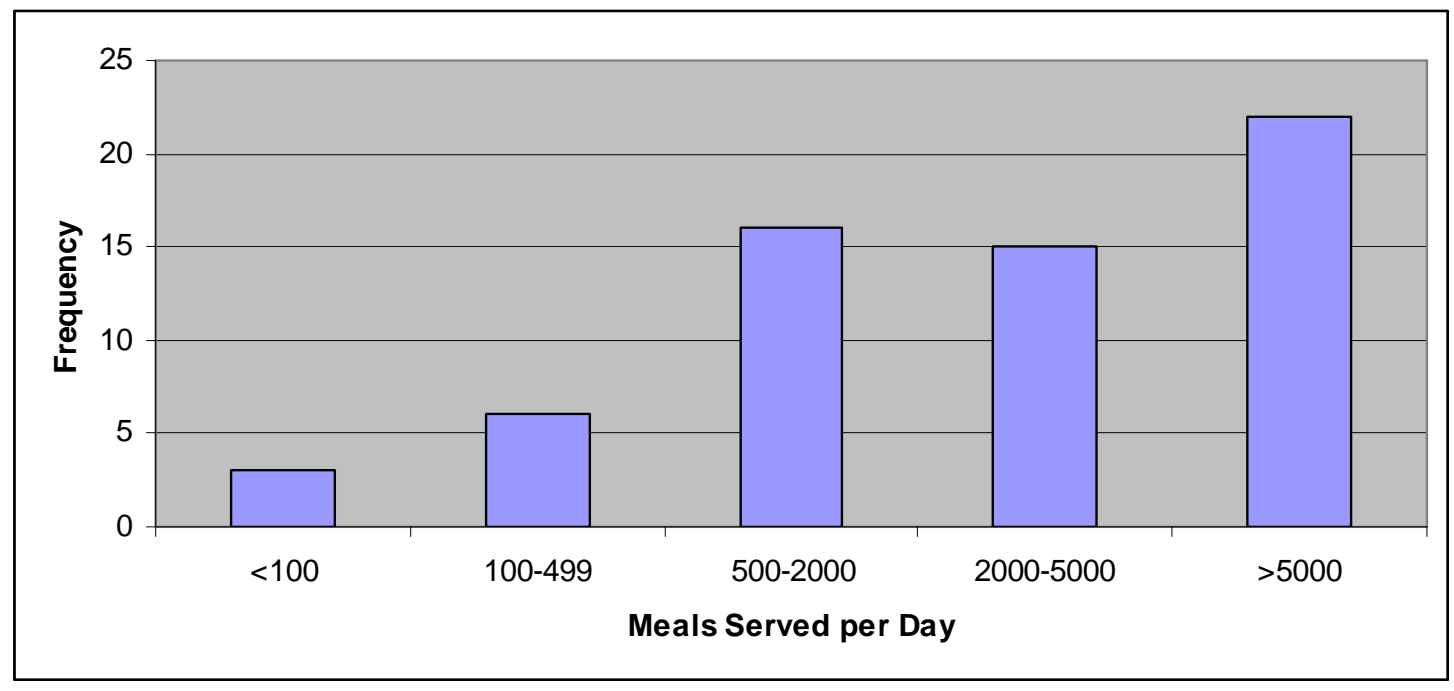

Figure 3.2 Size of the organization for final survey respondents (meals per day) $(\mathrm{N}=62)$ 


\subsubsection{Type of organization}

The type of organization, either hospital or college/university (public or private), is shown in Figure 3.3.

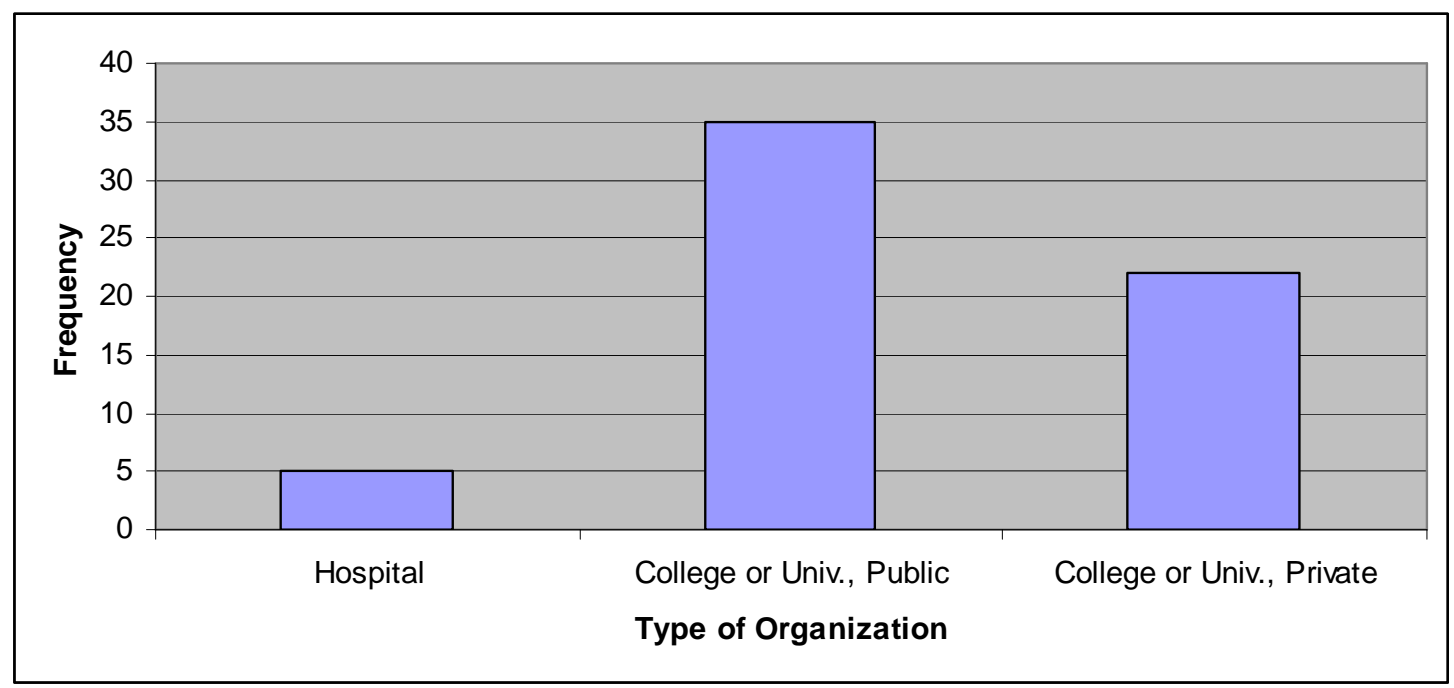

Figure 3.3 Type of the organization for final survey respondents $(\mathrm{N}=62)$

When asked whether the respondent was part of a group purchasing organization, $51.5 \%$ responded that they were and $48.5 \%$ responded that they were not.

\subsubsection{Final survey descriptive statistics}

\subsubsection{Perceived priorities of host organization, end customer, and food purchasing organization}

Using a seven-point scale of agreement, where 1 means "strongly disagree" and 7 means "strongly agree," respondents were given four statements about purchasing priorities.

Respondents were asked about their agreement with each of these statements for their host organization (if they were a contracted employee), their end customer group and their purchasing group. The statements were as follows:

Please indicate your level of agreement with the following statements regarding purchasing practices: [My Food Purchasing Organization] or [My End Customer]...

- is fully committed to sustainable purchasing practices. (Sustainable Purchasing)

- encourages purchases of local products whenever possible. (Local Purchasing)

- sees packaging waste reduction as an important goal. (Packaging Waste Reduction)

- $\quad$ sees food waste reduction as an important goal. (Food Waste Reduction) 


\subsubsection{Commitment to purchasing practices}

Table 3.1 Perceived priorities of host organization

Perceived Priorities of Host Organization

1=Strongly Disagree to $7=$ Strongly Agree

\begin{tabular}{l|l|r|r|r|r}
\hline \multicolumn{2}{c|}{} & $\begin{array}{c}\text { Sustainable } \\
\text { Purchasing }\end{array}$ & $\begin{array}{c}\text { Local } \\
\text { Purchasing }\end{array}$ & $\begin{array}{c}\text { Packaging } \\
\text { Waste } \\
\text { Reduction }\end{array}$ & $\begin{array}{c}\text { Food } \\
\text { Waste } \\
\text { Reduction }\end{array}$ \\
\hline \multirow{2}{*}{$\mathrm{N}$} & Valid & 66 & 66 & 66 & 66 \\
\cline { 2 - 6 } & Missing & 0 & 0 & 0 & 0 \\
\hline Mean & 3.62 & 3.77 & 3.80 & 4.17 \\
\hline Median & 4.00 & 4.00 & 4.00 & 4.00 \\
\hline \multicolumn{2}{l|}{ Mode } & 4 & 4 & 4 & 5 \\
\hline \multicolumn{2}{l|}{ Std. Deviation } & .924 & 1.005 & 1.011 & .921 \\
\hline
\end{tabular}

Respondents agreed most that their host organization saw food waste reduction as an important goal, followed by agreeing a little less that their host organization saw packaging waste reduction as an important goal. Respondents agreed even less that their host organization encouraged purchases of local products. The respondents overall did not agree as much that their host organization was committed to sustainable purchasing.

Table 3.2 Perceived priorities of end customer

Perceived Priorities of End Customer

1=Strongly Disagree to 7= Strongly Agree

\begin{tabular}{l|l|r|r|r|r}
\hline \multicolumn{2}{c|}{} & $\begin{array}{c}\text { Sustainable } \\
\text { Purchasing }\end{array}$ & $\begin{array}{c}\text { Local } \\
\text { Purchasing }\end{array}$ & $\begin{array}{c}\text { Packaging } \\
\text { Waste } \\
\text { Reduction }\end{array}$ & $\begin{array}{c}\text { Food } \\
\text { Waste } \\
\text { Reduction }\end{array}$ \\
\hline \multirow{2}{*}{$\mathrm{N}$} & Valid & 66 & 66 & 66 & 66 \\
\cline { 2 - 6 } & Missing & 0 & 0 & 0 & 0 \\
\hline Mean & 3.29 & 3.62 & 3.35 & 3.44 \\
\hline Median & 3.00 & 4.00 & 3.00 & 3.00 \\
\hline \multicolumn{2}{l|}{ Mode } & 3 & 4 & 4 & 3 \\
\hline \multicolumn{2}{l|}{ Std. Deviation } & .989 & .989 & 1.030 & 1.025 \\
\hline
\end{tabular}

Respondents agreed most that their end customer encouraged purchases of local products, followed by agreeing a little less that their end customer saw food waste reduction as an important goal. Respondents agreed even less that their end customer saw packaging waste reduction as important a goal. The respondents overall did not agree as much that their end customer was committed to sustainable purchasing. 
Table 3.3 Perceived priorities of food purchasing organization

\section{Perceived Priorities of Food Purchasing Organization}

1=Strongly Disagree to 7= Strongly Agree

\begin{tabular}{l|r|r|r|r|r}
\hline \multicolumn{2}{c|}{} & $\begin{array}{c}\text { Sustainable } \\
\text { Purchasing }\end{array}$ & $\begin{array}{c}\text { Local } \\
\text { Purchasing }\end{array}$ & $\begin{array}{c}\text { Packaging } \\
\text { Waste } \\
\text { Reduction }\end{array}$ & $\begin{array}{c}\text { Food } \\
\text { Waste } \\
\text { Reduction }\end{array}$ \\
\hline $\mathrm{N}$ & Valid & 14 & 14 & 14 & 14 \\
\cline { 2 - 6 } & Missing & 52 & 52 & 52 & 52 \\
\hline Mean & 4.00 & 4.07 & 4.14 & 4.43 \\
\hline Median & 4.00 & 4.50 & 4.50 & 5.00 \\
\hline Mode & 5 & 5 & 5 & 5 \\
\hline \multicolumn{2}{l|l}{ Std. Deviation } & 1.109 & 1.141 & 1.099 & .852 \\
\hline
\end{tabular}

Respondents agreed most that their food purchasing organization saw food waste reduction as an important goal, followed by agreeing a little less that their food purchasing organization saw packaging waste reduction as an important goal. Respondents agreed even less that their food purchasing organization encouraged purchases of local products. The respondents overall did not agree as much that their food purchasing organization was committed to sustainable purchasing.

\subsubsection{Contract flexibility}

When asked about the diversity of their suppliers, $29 \%$ of respondents had between two and five vendors; $33 \%$ had between six and 10 vendors; $14 \%$ had 11 to 20 vendors; and $23 \%$ had more than 20 vendors (percentages were rounded up).

When respondents were asked how much discretion they had regarding the choice of suppliers, $3 \%$ said that they had no discretion over supplier selection; $41 \%$ reported that a majority of purchases were required to be from one or two suppliers with limited discretion over categories like diary or produce; $17 \%$ reported that at least half of purchases were required to be from one or two suppliers with full discretion over categories like diary or produce; $12 \%$ reported that they had full discretion to purchase from a competitive group of "company authorized" suppliers; and $27 \%$ reported that they had full discretion to purchase from any supplier.

Using a five-point scale of agreement, where 1 means "no extent at all" and 5 means "to a large extent," respondents were given five statements about supplier support. Respondents were asked to rate each of these statements in terms of the extent to which their major supplier supported them in efforts to purchase sustainably and locally. The statements were as follows:

- Are you allowed to purchase what you want from other suppliers without negative consequences?

- Are you provided with financial incentives to purchase predominately from that supplier?

- Are you allowed renegotiation flexibility to address host organization sustainability requirements such as buying local foods?

- Can the supplier provide accurate data on which products are produced locally? 
- Can the supplier provide accurate data on which products are produced with green or sustainable practices?

Table 3.4 Support of dominant supplier for sustainable practices

Extent to which dominant supplier supports practices

$1=$ No extent at all to $5=$ To a large extent

\begin{tabular}{|c|c|c|c|c|c|c|}
\hline & & $\begin{array}{c}\text { Purchase from } \\
\text { other suppliers } \\
\text { without } \\
\text { negative } \\
\text { consequences }\end{array}$ & $\begin{array}{l}\text { Provided } \\
\text { financial } \\
\text { incentive to } \\
\text { purchase } \\
\text { from supplier }\end{array}$ & $\begin{array}{l}\text { Renegotiation } \\
\text { flexibility to } \\
\text { address Host Org } \\
\text { sustainability } \\
\text { requirements }\end{array}$ & $\begin{array}{c}\text { Supplier } \\
\text { can provide } \\
\text { data re: } \\
\text { local } \\
\text { products }\end{array}$ & $\begin{array}{c}\text { Supplier can } \\
\text { provide data } \\
\text { re: } \\
\text { sustainable } \\
\text { products }\end{array}$ \\
\hline \multirow[t]{2}{*}{$\mathrm{N}$} & Valid & 66 & 66 & 66 & 66 & 66 \\
\hline & Missing & 0 & 0 & 0 & 0 & 0 \\
\hline \multicolumn{2}{|c|}{ Mean } & 3.53 & 3.61 & 3.18 & 3.21 & 3.06 \\
\hline \multicolumn{2}{|c|}{ Median } & 4.00 & 4.00 & 3.00 & 3.00 & 3.00 \\
\hline \multicolumn{2}{|c|}{ Mode } & 5 & 5 & 4 & 3 & 3 \\
\hline \multicolumn{2}{|c|}{$\begin{array}{l}\text { Std. } \\
\text { Deviation }\end{array}$} & 1.268 & 1.508 & 1.264 & 1.157 & 1.080 \\
\hline
\end{tabular}

Overall, respondents rated the highest types of support from their supplier as "providing financial incentive to purchase from supplier," and second highest as "purchasing from other suppliers without negative consequences." The next highest types of support from the supplier was "renegotiation flexibility to address Host Org sustainability requirements," while "supplier can provide data re: local products" and "supplier can provide data re: sustainable products" were the lowest types of support from the supplier.

Using a five-point scale of agreement, where 1 means "no extent at all" and 5 means "to a large extent," respondents were given seven statements about host organization support. Respondents were asked to rate of each of these statements in terms of the extent to which their major supplier supported them in efforts to purchase sustainably and locally. For this question, respondents were separated into two different groups, contracted employees and host organization employees. The statements were as follows:

- Supports efforts to procure sustainable and local products

- Supports efforts to utilize "green" cleaning products

- Encourages promoting benefits of "green" products

- Encourages promoting benefits of "green" waste systems

- Encourages building partnerships with local growers and producers

- Requires providing reports documenting percent purchased "green" products

- Requires meeting established minimums of local food sourcing and/or organics 
Table 3.5 Host organization support of sustainable practices (for contracted employees)

Extent to which host organization supports practices (of contracted employee)

$1=$ No extent at all to $5=$ To a large extent

\begin{tabular}{l|r|r|r|r|r|r}
\hline & \multicolumn{2}{|c|}{$\mathrm{N}$} & & & \multicolumn{1}{c|}{$\begin{array}{c}\text { Std. } \\
\text { Deviation }\end{array}$} \\
\cline { 2 - 6 } & Valid & Missing & Mean & Median & Mode & 1.099 \\
\hline $\begin{array}{l}\text { Supports efforts to procure } \\
\text { sustainable and local products }\end{array}$ & 14 & 52 & 3.86 & 4.00 & 5 & 1.453 \\
\hline $\begin{array}{l}\text { Supports efforts to utilize } \\
\text { "green" cleaning products }\end{array}$ & 14 & 52 & 3.43 & 4.00 & $4^{\mathrm{a}}$ & 1.326 \\
\hline $\begin{array}{l}\text { Encourages promoting benefits } \\
\text { of "green" products }\end{array}$ & 14 & 52 & 3.71 & 4.00 & 5 & 1.167 \\
\hline $\begin{array}{l}\text { Encourages promoting benefits } \\
\text { of "green" waste systems }\end{array}$ & 14 & 52 & 3.86 & 4.00 & 5 & 1.555 \\
\hline $\begin{array}{l}\text { Encourages building partnerships } \\
\text { with local growers and producers }\end{array}$ & 14 & 52 & 3.57 & 4.00 & 5 & 1.684 \\
\hline $\begin{array}{l}\text { Requires providing reports } \\
\text { documenting percent purchased } \\
\text { "green" products }\end{array}$ & 14 & 52 & 2.71 & 2.00 & 1 & 1.646 \\
\hline $\begin{array}{l}\text { Requires meeting established } \\
\text { minimums of local food sourcing } \\
\text { and/or organics }\end{array}$ & 14 & 52 & 2.64 & 2.50 & 1 & \\
\hline
\end{tabular}

a. Multiple modes exist. The smallest value is shown

For respondents who were contracted employees, the types of host organization support that were rated the highest overall were both "supports efforts to procure sustainable and local products" and "encourages promoting benefits of 'green' waste systems." The next highest types of support were "encourages promoting benefits of 'green' products," "encourages building partnerships with local growers and producers," and "supports efforts to utilize 'green' cleaning products." The lowest-rated types of support were "requires providing reports documenting percent purchased 'green' products" and "requires meeting established minimums of local food sourcing and/or organics." 
Table 3.6 Host organization support of sustainable practices (for host org employees)

Extent to which Host Organization supports practices (of Host Org Employee)

$1=$ No extent at all to $5=$ To a large extent

\begin{tabular}{|c|c|c|c|c|c|c|}
\hline & \multicolumn{2}{|c|}{$\mathrm{N}$} & \multirow[b]{2}{*}{ Mean } & \multirow[b]{2}{*}{ Median } & \multirow[b]{2}{*}{ Mode } & \multirow{2}{*}{$\begin{array}{c}\text { Std. } \\
\text { Deviation }\end{array}$} \\
\hline & Valid & Missing & & & & \\
\hline $\begin{array}{l}\text { Financial incentive to purchase } \\
\text { from supplier }\end{array}$ & 48 & 18 & 3.69 & 4.00 & 5 & 1.206 \\
\hline $\begin{array}{l}\text { Supports efforts to utilize } \\
\text { "green" cleaning products }\end{array}$ & 48 & 18 & 3.58 & 4.00 & $3^{\mathrm{a}}$ & 1.182 \\
\hline $\begin{array}{l}\text { Encourages promoting benefits } \\
\text { of "green" products }\end{array}$ & 48 & 18 & 3.48 & 4.00 & 4 & 1.203 \\
\hline $\begin{array}{l}\text { Encourages promoting benefits } \\
\text { of "green" waste systems }\end{array}$ & 48 & 18 & 3.65 & 4.00 & 5 & 1.246 \\
\hline $\begin{array}{l}\text { Encourages building } \\
\text { partnerships with local growers } \\
\text { and producers }\end{array}$ & 47 & 19 & 3.32 & 4.00 & 4 & 1.353 \\
\hline $\begin{array}{l}\text { Requires providing reports } \\
\text { documenting percent purchased } \\
\text { "green" products }\end{array}$ & 48 & 18 & 2.00 & 1.00 & 1 & 1.255 \\
\hline $\begin{array}{l}\text { Requires meeting established } \\
\text { minimums of local food } \\
\text { sourcing and/or organics }\end{array}$ & 48 & 18 & 1.69 & 1.00 & 1 & .971 \\
\hline
\end{tabular}

For respondents who were host organization employees, the types of host organization support that were rated the highest overall were "financial incentive to purchase from supplier" and "encourages promoting benefits of 'green' waste systems." The next highest type of support was "supports efforts to utilize 'green' cleaning products," "encourages promoting benefits of 'green' products," and "encourages building partnerships with local growers and producers." The lowest-rated types of support were "requires providing reports documenting percent purchased 'green' products" and "requires meeting established minimums of local food sourcing and/or organics."

\subsubsection{Facility flexibility}

When respondents were asked to describe their level of food preparation facilities, $58 \%$ had a full bakery and kitchen; 36\% had a full kitchen and simple bakery (cookies, cakes, etc); $5 \%$ had a full kitchen that could do simple food prep (chopping, mixing) and baking; and $2 \%$ of respondents had either a kitchen with limited food prep and bakery or a facility without food prep or mixing.

When respondents were asked to describe their level of food delivery, they chose between the options listed below:

- Vending machines of pre-packaged food and snacks 
- Above choices and grab 'n go (pre-made food items purchased from external sources)

- Above choices and self serve (salad bar)

- Above choices and quick service (food items quickly prepared to order)

- Above choices with full-service dining (sit down with menu and service)

Respondents said that $62 \%$ had full-service dining; $33 \%$ had quick service; $3 \%$ had self serve; and $1.5 \%$ of respondents had only vending machines with pre-packaged foods and snacks.

When respondents were asked about the level of input that their organization had during the design of the current kitchen facilities, $15 \%$ had no input at all; $14 \%$ had limited input; $20 \%$ had some input; $27 \%$ had significant input; and 24\% said that their organization designed the kitchen.

\subsubsection{Recycling, reuse, and waste (composting and donation)}

Respondents were asked about their recycling, reuse, and waste reduction. The results are summarized in Table 3.7.

Table 3.7 Results for recycling, reuse, food composting, and food donation for final survey ( $\mathrm{N}=62$ Overall)

\begin{tabular}{|c|c|c|c|c|c|c|c|}
\hline & \multicolumn{5}{|c|}{ Implementation Percentage } & \multirow{2}{*}{$\begin{array}{l}\% \text { Reduced } \\
\text { for this } \\
\text { type of } \\
\text { waste }\end{array}$} & \multirow[b]{2}{*}{$\begin{array}{l}\mathrm{N} \text { for } \% \\
\text { Reduced }\end{array}$} \\
\hline & $\begin{array}{l}\text { Not } \\
\text { considering }\end{array}$ & & Partially & & Fully & & \\
\hline $\begin{array}{l}\text { Recycling - } \\
\text { Cardboard Boxes }\end{array}$ & $3 \%$ & $2 \%$ & $26 \%$ & $52 \%$ & $18 \%$ & $85 \%$ & 48 \\
\hline $\begin{array}{l}\text { Recycling - Glass } \\
\text { Containers }\end{array}$ & $19 \%$ & $16 \%$ & $16 \%$ & $40 \%$ & $8 \%$ & $71 \%$ & 35 \\
\hline $\begin{array}{l}\text { Recycling - } \\
\text { Metal/Cans }\end{array}$ & $5 \%$ & $16 \%$ & $23 \%$ & $50 \%$ & $6 \%$ & $72 \%$ & 42 \\
\hline Recycling - Plastic & $6 \%$ & $13 \%$ & $21 \%$ & $48 \%$ & $11 \%$ & $69 \%$ & 40 \\
\hline Recycling - Paper & $2 \%$ & $5 \%$ & $24 \%$ & $58 \%$ & $11 \%$ & $62 \%$ & 45 \\
\hline Reuse - Plastic & $34 \%$ & $18 \%$ & $26 \%$ & $18 \%$ & $5 \%$ & $42 \%$ & 25 \\
\hline $\begin{array}{l}\text { Compost - Food } \\
\text { Waste }\end{array}$ & $29 \%$ & $29 \%$ & $19 \%$ & $15 \%$ & $8 \%$ & $53 \%$ & 27 \\
\hline $\begin{array}{l}\text { Reduce - less } \\
\text { individual servings } \\
\text { of drinks in } \\
\text { bottles/cans }\end{array}$ & $27 \%$ & $34 \%$ & $24 \%$ & $10 \%$ & $5 \%$ & $36 \%$ & 19 \\
\hline $\begin{array}{l}\text { Donate - excess } \\
\text { foods to hunger } \\
\text { relief agencies }\end{array}$ & $31 \%$ & $23 \%$ & $21 \%$ & $13 \%$ & $13 \%$ & $33 \%$ & 26 \\
\hline $\begin{array}{l}\text { Donate - excess } \\
\text { foods for non- } \\
\text { human } \\
\text { consumption }\end{array}$ & $71 \%$ & $16 \%$ & $6 \%$ & $5 \%$ & $2 \%$ & $50 \%$ & 7 \\
\hline
\end{tabular}


As can be seen in Table 3.7, very few organizations consider their recycling, reuse and waste reductions effort to be fully implemented. For recycling, most respondents checked the box between "partially" and "fully" implemented, and indicated that their programs allow them to recycle between $62 \%$ and $85 \%$ of the material. These results are consistent with the pilot survey, but with slightly lower number for percentage recycled. Reuse, composting, and donation of waste is practiced by a small minority of the organizations.

\subsubsection{Purchasing practices}

Respondents ranked their level of implementation for several different purchasing practices, using a five-point scale where 1 means "not considering" and 5 means "formal policy with improvement goals." Respondents also were asked to enter their amount purchased for each practice of total purchased. The purchasing practices statements were:

- Purchase locally produced foods when available from distributor

- Purchase locally produced foods directly from source

- Purchase third-party certified foods when available (organic, sustainable, hormone free, etc.)

- Purchase bulk food products to reduce packaging waste

- Purchase food products with reusable containers or returnable totes

Table 3.8 Implementation of purchasing practices

Implementation of Purchasing Practices of Respondents

$1=$ Not considering to $5=$ Formal policy with improvement goals

\begin{tabular}{|c|c|c|c|c|c|c|}
\hline & & $\begin{array}{c}\text { Purchase } \\
\text { locally } \\
\text { produced } \\
\text { foods when } \\
\text { available from } \\
\text { distributor } \\
\end{array}$ & $\begin{array}{l}\text { Purchase } \\
\text { locally } \\
\text { produced } \\
\text { foods } \\
\text { directly } \\
\text { from source }\end{array}$ & $\begin{array}{l}\text { Purchased } \\
\text { third-party } \\
\text { certified } \\
\text { foods when } \\
\text { available } \\
\end{array}$ & $\begin{array}{l}\text { Purchase bulk } \\
\text { food products } \\
\text { to reduce } \\
\text { packaging } \\
\text { waste } \\
\end{array}$ & $\begin{array}{l}\text { Purchase food } \\
\text { products with } \\
\text { reusable } \\
\text { containers or } \\
\text { returnable totes }\end{array}$ \\
\hline \multirow[t]{2}{*}{$\bar{N}$} & Valid & 66 & 66 & 66 & 66 & 66 \\
\hline & Missing & 0 & 0 & 0 & 0 & 0 \\
\hline \multicolumn{2}{|c|}{ Mean } & 3.21 & 2.79 & 2.59 & 3.02 & 2.09 \\
\hline \multicolumn{2}{|c|}{ Median } & 3.00 & 3.00 & 3.00 & 3.00 & 2.00 \\
\hline \multicolumn{2}{|c|}{ Mode } & 3 & 3 & 3 & 3 & 1 \\
\hline \multicolumn{2}{|c|}{ Std. Deviation } & .985 & 1.209 & 1.202 & 1.000 & 1.119 \\
\hline
\end{tabular}

Respondents rated "purchase locally produced foods when available from distributor" as overall most implemented and "purchase bulk foods products to reduce packaging waste" as next most implemented. "Purchase locally produced foods directly from source" was the next most implemented practice; "purchased third-party certified foods when available" was the next less implemented practice; and "purchase food products with reusable containers or returnable totes" was the least implemented practice overall. 
Table 3.9 Purchasing practices as percentage of total if implemented

\begin{tabular}{|c|c|c|c|c|c|c|}
\hline \multicolumn{7}{|c|}{ Percent of Implementation of Purchasing Practices of Respondents } \\
\hline & & $\begin{array}{c}\text { Purchase } \\
\text { locally } \\
\text { produced } \\
\text { foods when } \\
\text { available from } \\
\text { distributor }\end{array}$ & $\begin{array}{c}\text { Purchase } \\
\text { locally } \\
\text { produced } \\
\text { foods } \\
\text { directly } \\
\text { from source }\end{array}$ & $\begin{array}{l}\text { Purchased } \\
\text { third-party } \\
\text { certified } \\
\text { foods when } \\
\text { available }\end{array}$ & $\begin{array}{l}\text { Purchase bulk } \\
\text { food products } \\
\text { to reduce } \\
\text { packaging } \\
\text { waste }\end{array}$ & $\begin{array}{l}\text { Purchase food } \\
\text { products with } \\
\text { reusable } \\
\text { containers or } \\
\text { returnable } \\
\text { totes } \\
\end{array}$ \\
\hline \multirow[t]{2}{*}{$\mathrm{N}$} & Valid & 49 & 45 & 43 & 40 & 34 \\
\hline & Missing & 17 & 21 & 23 & 26 & 32 \\
\hline \multicolumn{2}{|c|}{ Mean } & $19.35 \%$ & $11.80 \%$ & $10.61 \%$ & $37.43 \%$ & $8.21 \%$ \\
\hline \multicolumn{2}{|c|}{ Median } & $15.00 \%$ & $5.00 \%$ & $5.00 \%$ & $32.50 \%$ & $0 \%$ \\
\hline \multicolumn{2}{|c|}{ Mode } & $10 \%$ & $10 \%$ & $0 \%$ & $0 \%^{\mathrm{a}}$ & $0 \%$ \\
\hline \multicolumn{2}{|c|}{ Std. Deviation } & $16.00 \%$ & $17.368 \%$ & $13.25 \%$ & $31.16 \%$ & $12.79 \%$ \\
\hline
\end{tabular}

In addition to rating the level of implementation of the purchasing practice listed above, respondents were asked to provide a percent of total purchased for each of the purchasing practices. The purchasing practice with the highest overall percentage of total purchased was "purchase bulk foods products to reduce packaging waste" at $37 \%$, while the lowest overall purchasing practice was "purchase food products with reusable containers or returnable totes" at $8 \%$.

Respondents ranked their level of implementation for three different menu planning practices, using a five-point scale where 1 means "not considering" and 5 means "formal policy with improvement goals." Respondents were also asked to enter their amount menu planning for each practice, of total purchased. The menu planning practices statements were:

- Plan menus with priority given to seasonal produce availability

- Plan menus to reduce consumption of animal products

- Plan menus to promote healthy diets 
Table 3.10 Menu planning practices

Menu Planning Practices of Respondents

$1=$ Not considering to $5=$ Formal policy with improvement goals

\begin{tabular}{l|l|r|r|r}
\hline \multicolumn{2}{l|}{} & $\begin{array}{c}\text { Plan menus with priority } \\
\text { given to seasonal } \\
\text { produce availability }\end{array}$ & $\begin{array}{c}\text { Plan menus to } \\
\text { reduce consumption } \\
\text { of animal products }\end{array}$ & $\begin{array}{c}\text { Plan menus to } \\
\text { promote healthy } \\
\text { diets }\end{array}$ \\
\hline \multirow{2}{*}{$\mathrm{N}$} & Valid & 66 & 66 & 66 \\
\cline { 2 - 6 } & Missing & 0 & 0 & 0 \\
\hline Mean & 3.24 & 2.00 & 3.58 \\
\hline Median & 3.00 & 1.00 & 3.50 \\
\hline Mode & 3 & 1 & 3 \\
\hline Std. Deviation & .929 & 1.289 & .895 \\
\hline
\end{tabular}

Overall, respondents rated "plan menus to promote healthy diets" as the most implemented menu planning practice of the choices; "plan menus with priority given to seasonal produce availability" as a less implemented practice; and "plan menus to reduce consumption of animal products" as the least implemented.

Table 3.11 Menu planning practices as percentage of total if implemented

\begin{tabular}{|c|c|c|c|c|}
\hline \multicolumn{5}{|c|}{ Percent of Implementation of Menu Planning Practices of Respondents } \\
\hline & & $\begin{array}{c}\text { Plan menus with priority } \\
\text { given to seasonal } \\
\text { produce availability }\end{array}$ & $\begin{array}{l}\text { Plan menus to } \\
\text { reduce consumption } \\
\text { of animal products }\end{array}$ & $\begin{array}{l}\text { Plan menus to } \\
\text { promote healthy } \\
\text { diets }\end{array}$ \\
\hline \multirow[t]{2}{*}{$\mathrm{N}$} & Valid & 50 & 43 & 51 \\
\hline & Missing & 16 & 23 & 15 \\
\hline \multicolumn{2}{|c|}{ Mean } & $33.14 \%$ & $14.53 \%$ & $51.27 \%$ \\
\hline \multicolumn{2}{|c|}{ Median } & $27.50 \%$ & $5.00 \%$ & $50.00 \%$ \\
\hline \multicolumn{2}{|c|}{ Mode } & $50 \%$ & $0 \%$ & $50 \%$ \\
\hline \multicolumn{2}{|c|}{ Std. Deviation } & $23.740 \%$ & $21.926 \%$ & 28.824 \\
\hline
\end{tabular}

In addition to rating the level of implementation of the menu planning practice listed above, respondents were asked to provide a percent of total menu planning for each of the practices. The menu planning practice with the highest average percentage of total practices was "plan menus to promote healthy diets" at $51 \%$, while "plan menus with priority given to seasonal produce availability" was less overall percentage at 33\%. "Plan menus to reduce consumption of animal products" was the lowest average percentage of total menu planning practices at $15 \%$.

\subsubsection{Supplier characteristics}

When asked to categorize their supplier for a majority of their sustainable and local products, $9 \%$ of respondents reported individual farmers as their major supplier. Of the respondents, $35 \%$ reported "Local produce, dairy and/ or meat distributor predominately" as their major supplier for sustainable and local products; $26 \%$ reported "National full service distributor 
predominately;" 24\% reported "National and Local distributors almost equally;" and 6\% reported "Other."

The "Other" responses were:

- A mix of farmer/supplier and our primary distributor

- National distributor and dairy

- Local produce distributor

- Local farmers and meat/dairy distributors

\subsubsection{Final survey alignment between host organization, end customer and food purchasing organization}

In this section, the differences in the respondent's perceptions of the host organization, end customer, and third-party food purchasing organization (where relevant) are described. The respondent is asked to evaluate whether the different parties are committed or supportive of sustainable purchasing practices, local produced products, packaging waste reduction, and food waste reduction.

\subsubsection{For host org vs. end customer}

A paired-sample t-test was conducted to evaluate whether the respondent's perceived level of commitment to four topics was different between their host organization and their end customer. 
Table 3.12 t-test of respondent's perceived priorities of their host organization compared to their end customer

\begin{tabular}{|c|c|c|c|c|c|c|c|c|}
\hline \multicolumn{9}{|c|}{$\begin{array}{c}\text { Respondent's perceived priorities: } \\
\text { Comparing Host Organization and End Customer } \\
\text { Paired t-test }\end{array}$} \\
\hline & & Mean & $\mathrm{N}$ & $\begin{array}{c}\text { Std. } \\
\text { Deviation }\end{array}$ & $\begin{array}{l}\text { Std. Error } \\
\text { Mean }\end{array}$ & $\mathrm{t}$ & $\mathrm{df}$ & $\begin{array}{c}\text { Sig. } \\
\text { (2-tailed) }\end{array}$ \\
\hline \multirow[t]{2}{*}{$\begin{array}{l}\text { Sustainable } \\
\text { Purchasing }\end{array}$} & $\begin{array}{l}\text { Host } \\
\text { Organization }\end{array}$ & 3.62 & 66 & .924 & .114 & \multirow{2}{*}{2.900} & \multirow{2}{*}{65} & \multirow{2}{*}{.005} \\
\hline & End Customer & 3.29 & 66 & .989 & .122 & & & \\
\hline \multirow[t]{2}{*}{$\begin{array}{l}\text { Local } \\
\text { Purchasing }\end{array}$} & $\begin{array}{l}\text { Host } \\
\text { Organization }\end{array}$ & 3.77 & 66 & 1.005 & .124 & \multirow{2}{*}{1.320} & \multirow{2}{*}{65} & \multirow{2}{*}{.191} \\
\hline & End Customer & 3.62 & 66 & .989 & .122 & & & \\
\hline \multirow{2}{*}{$\begin{array}{l}\text { Packaging } \\
\text { Waste } \\
\text { Reduction }\end{array}$} & $\begin{array}{l}\text { Host } \\
\text { Organization }\end{array}$ & 3.80 & 66 & 1.011 & .124 & \multirow[t]{2}{*}{3.321} & \multirow[t]{2}{*}{65} & \multirow[t]{2}{*}{.001} \\
\hline & End Customer & 3.35 & 66 & 1.030 & .127 & & & \\
\hline \multirow[t]{2}{*}{$\begin{array}{l}\text { Food Waste } \\
\text { Reduction }\end{array}$} & $\begin{array}{l}\text { Host } \\
\text { Organization }\end{array}$ & 4.17 & 66 & .921 & .113 & \multirow{2}{*}{4.937} & \multirow{2}{*}{65} & \multirow{2}{*}{.000} \\
\hline & End Customer & 3.44 & 66 & 1.025 & .126 & & & \\
\hline
\end{tabular}

The results indicated that the mean scores for perceived commitment to sustainable purchasing, packaging waste reduction, and food waste reduction were all significantly different between the respondent's perceptions of their host organization and their end customer. In these cases, the host organization was perceived to have a higher level of commitment or support relative to the customer. On the other hand, the perceived commitment to local purchasing was not significantly different between the respondent's perceptions of their host organization $(\mathrm{M}=3.77, \mathrm{SD}=1)$ and their end customer $(\mathrm{M}=3.62, \mathrm{SD}=0.99), \mathrm{t}(65)=1.32, \mathrm{p}=0.19$.

\subsubsection{For host org vs. food purchasing organization}

A paired-sample t-test was conducted to evaluate whether the respondent's perceived level of commitment to four topics was different between their host organization and their food purchasing organization. 
Table 3.13 t-test of respondent's perceived priorities of their host organization compared to their food purchasing organization

\begin{tabular}{|c|c|c|c|c|c|c|c|c|}
\hline \multicolumn{9}{|c|}{$\begin{array}{c}\text { Respondent's perceived priorities: } \\
\text { Comparing Host Organization and Food Purchasing Organization } \\
\text { Paired t-test }\end{array}$} \\
\hline & & Mean & $\mathrm{N}$ & $\begin{array}{c}\text { Std. } \\
\text { Deviation }\end{array}$ & $\begin{array}{l}\text { Std. Error } \\
\text { Mean }\end{array}$ & $\mathrm{t}$ & $\mathrm{df}$ & $\begin{array}{c}\text { Sig. } \\
\text { (2-tailed) }\end{array}$ \\
\hline \multirow[t]{2}{*}{$\begin{array}{l}\text { Sustainable } \\
\text { Purchasing }\end{array}$} & $\begin{array}{l}\text { Host } \\
\text { Organization }\end{array}$ & 3.79 & 14 & 1.051 & .281 & \multirow[b]{2}{*}{-1.147} & \multirow[b]{2}{*}{13} & \multirow[b]{2}{*}{.272} \\
\hline & $\begin{array}{l}\text { Food Purchasing } \\
\text { Organization }\end{array}$ & 4.00 & 14 & 1.109 & .296 & & & \\
\hline \multirow[t]{2}{*}{$\begin{array}{l}\text { Local } \\
\text { Purchasing }\end{array}$} & $\begin{array}{l}\text { Host } \\
\text { Organization }\end{array}$ & 4.07 & 14 & 1.141 & .305 & \multirow{2}{*}{.000} & \multirow{2}{*}{13} & \multirow{2}{*}{1.000} \\
\hline & $\begin{array}{l}\text { Food Purchasing } \\
\text { Organization }\end{array}$ & 4.07 & 14 & 1.141 & .305 & & & \\
\hline \multirow{2}{*}{$\begin{array}{l}\text { Packaging } \\
\text { Waste } \\
\text { Reduction }\end{array}$} & $\begin{array}{l}\text { Host } \\
\text { Organization }\end{array}$ & 3.79 & 14 & 1.369 & .366 & \multirow[b]{2}{*}{-1.325} & \multirow{2}{*}{13} & \multirow{2}{*}{.208} \\
\hline & $\begin{array}{l}\text { Food Purchasing } \\
\text { Organization }\end{array}$ & 4.14 & 14 & 1.099 & .294 & & & \\
\hline \multirow[t]{2}{*}{$\begin{array}{l}\text { Food Waste } \\
\text { Reduction }\end{array}$} & $\begin{array}{l}\text { Host } \\
\text { Organization }\end{array}$ & 4.07 & 14 & 1.269 & .339 & \multirow{2}{*}{-1.099} & \multirow[b]{2}{*}{13} & \multirow{2}{*}{.292} \\
\hline & $\begin{array}{l}\text { Food Purchasing } \\
\text { Organization }\end{array}$ & 4.43 & 14 & .852 & .228 & & & \\
\hline
\end{tabular}

The results indicated that the mean scores for perceived commitment to sustainable purchasing, local purchasing, packaging waste reduction, and food waste reduction were not significantly different between the respondent's perceptions of their host organization and their food purchasing organization.

\subsubsection{For end customer vs. food purchasing organization}

A paired-sample t-test was conducted to evaluate whether the respondent's perceived level of commitment to four topics was different between their end customer and their food purchasing organization. 
Table 3.14 t-test of respondent's perceived priorities of their end customer compared to their food purchasing organization

\begin{tabular}{|c|c|c|c|c|c|c|c|c|}
\hline \multicolumn{9}{|c|}{$\begin{array}{c}\text { Respondent's perceived priorities: } \\
\text { Comparing End Customer and Food Purchasing Organization } \\
\text { Paired t-test }\end{array}$} \\
\hline & & Mean & $\mathrm{N}$ & $\begin{array}{c}\text { Std. } \\
\text { Deviation }\end{array}$ & $\begin{array}{l}\text { Std. Error } \\
\text { Mean }\end{array}$ & $\mathrm{t}$ & df & $\begin{array}{c}\text { Sig. } \\
\text { (2-tailed) }\end{array}$ \\
\hline \multirow{2}{*}{$\begin{array}{l}\text { Sustainable } \\
\text { Purchasing }\end{array}$} & End Customer & 3.57 & 14 & 1.284 & .343 & \multirow[t]{2}{*}{-1.883} & \multirow[t]{2}{*}{13} & \multirow[t]{2}{*}{.082} \\
\hline & $\begin{array}{l}\text { Food Purchasing } \\
\text { Organization }\end{array}$ & 4.00 & 14 & 1.109 & .296 & & & \\
\hline \multirow{2}{*}{$\begin{array}{l}\text { Local } \\
\text { Purchasing }\end{array}$} & End Customer & 3.93 & 14 & 1.328 & .355 & \multirow[t]{2}{*}{-.458} & \multirow[t]{2}{*}{13} & \multirow[t]{2}{*}{.655} \\
\hline & $\begin{array}{l}\text { Food Purchasing } \\
\text { Organization }\end{array}$ & 4.07 & 14 & 1.141 & .305 & & & \\
\hline \multirow{2}{*}{$\begin{array}{l}\text { Packaging } \\
\text { Waste } \\
\text { Reduction }\end{array}$} & End Customer & 3.64 & 14 & 1.277 & .341 & \multirow[t]{2}{*}{-2.876} & \multirow[t]{2}{*}{13} & \multirow[t]{2}{*}{.013} \\
\hline & $\begin{array}{l}\text { Food Purchasing } \\
\text { Organization }\end{array}$ & 4.14 & 14 & 1.099 & .294 & & & \\
\hline \multirow{2}{*}{$\begin{array}{l}\text { Food Waste } \\
\text { Reduction }\end{array}$} & End Customer & 3.93 & 14 & 1.269 & .339 & \multirow[t]{2}{*}{-1.989} & \multirow[t]{2}{*}{13} & \multirow[t]{2}{*}{.068} \\
\hline & $\begin{array}{l}\text { Food Purchasing } \\
\text { Organization }\end{array}$ & 4.43 & 14 & .852 & .228 & & & \\
\hline
\end{tabular}

The results indicated that the mean scores for perceived commitment to sustainable purchasing, local purchasing, and food waste reduction were not significantly different between the respondent's perceptions of their end customer and their food purchasing organization. The perceived commitment to packaging waste reduction was significantly different between the respondent's perceptions of their end customer $(\mathrm{M}=3.64, \mathrm{SD}=1.28)$ and their food purchasing organization $(\mathrm{M}=4.14, \mathrm{SD}=1.10), \mathrm{t}(13)=2.88, \mathrm{p}=0.013$, where there is a higher level of perceived commitment to packaging waste reduction for the food purchasing organization than the end customer. 
Table 3.15 Summary of perceived priorities t-tests

\begin{tabular}{|c|c|c|c|}
\hline & Host Org & End Customer & Food Purchasing Organization \\
\hline $\begin{array}{l}\text { Sustainable } \\
\text { Purchasing }\end{array}$ & $\begin{array}{l}\text { Somewhat high } \\
\text { perceived commitment } \\
\mathrm{HO}>\mathrm{EC} \\
\mathrm{HO}=\mathrm{FPG}\end{array}$ & $\begin{array}{l}\text { Somewhat lower } \\
\text { perceived commitment } \\
\text { HO }>\text { EC } \\
\text { EC }=\text { FPG }\end{array}$ & $\begin{array}{l}\text { Somewhat high perceived } \\
\text { commitment (equal to both HO } \\
\& \text { EC within FPG subset) } \\
\text { EC = FPG } \\
\text { HO = FPG }\end{array}$ \\
\hline $\begin{array}{l}\text { Local } \\
\text { Purchasing }\end{array}$ & $\begin{array}{l}\text { Somewhat high } \\
\text { perceived commitment } \\
\text { HO = EC } \\
\text { HO = FPG }\end{array}$ & $\begin{array}{l}\text { Somewhat high } \\
\text { perceived commitment } \\
\mathrm{HO}=\mathrm{EC} \\
\mathrm{EC}=\mathrm{FPG}\end{array}$ & $\begin{array}{l}\text { Somewhat high perceived } \\
\text { commitment } \\
\text { HO = FPG } \\
\text { EC = FPG }\end{array}$ \\
\hline $\begin{array}{l}\text { Packaging } \\
\text { Waste } \\
\text { Reduction }\end{array}$ & $\begin{array}{l}\text { Somewhat high } \\
\text { perceived commitment } \\
\text { HO > EC } \\
\text { HO = FPG }\end{array}$ & $\begin{array}{l}\text { Somewhat lower } \\
\text { perceived commitment } \\
\text { HO }>\text { EC } \\
\text { EC }<\text { FPG }\end{array}$ & $\begin{array}{l}\text { Somewhat high perceived } \\
\text { commitment } \\
\text { HO = FPG } \\
\text { EC < FPG }\end{array}$ \\
\hline $\begin{array}{l}\text { Food } \\
\text { Waste } \\
\text { Reduction }\end{array}$ & $\begin{array}{l}\text { Somewhat high } \\
\text { perceived commitment } \\
\mathrm{HO}=\mathrm{FPG} \\
\mathrm{HO}>\mathrm{EC}\end{array}$ & 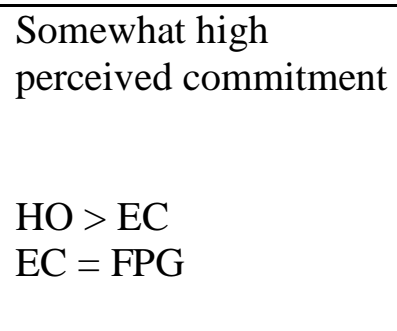 & $\begin{array}{l}\text { Somewhat high perceived } \\
\text { commitment (equal to both HO } \\
\text { \& EC within FPG subset) } \\
\text { HO = FPG } \\
\text { EC = FPG }\end{array}$ \\
\hline
\end{tabular}

\subsubsection{Construct operationalization and validation}

One of the objectives of this research was to create a set of scales that could be used in the future to look at sustainable purchasing practices in the institutional supply chain. An exploratory factor analysis was first performed to eliminate items that did not conform to a relevant factor (cross or week loadings). Using SPSS version 16.0, principal component analysis was performed with a Varimax rotation and accepted only those factors with an Eigenvalue greater than one (Hair et al. 2009). Next, the reliability or internal consistency of the construct items was checked amongst themselves using Cronbach's alpha. When alpha is above .70, this indicates that the scale has good reliability. Although, for new studies a lower threshold such as .60 is considered acceptable (Hair et al. 2009). The resulting constructs and their related items are provided in Table 3.16. All the constructs show reasonable reliability. The corresponding items are then averaged together to create one construct. For example, the six recycling items are averaged together to form one construct called "Recycling Practices." 
Table 3.16 Construct items and reliability

\begin{tabular}{|c|c|c|}
\hline Scale & Item & Description \\
\hline \multirow{6}{*}{$\begin{array}{l}\text { Recycling Practices } \\
\alpha=.88\end{array}$} & Q10.1 & Recycling Cardboard Boxes \\
\hline & Q10.2 & Recycling Glass Containers \\
\hline & Q10.3 & Recycling Metal Cans \\
\hline & Q10.4 & Recycling Plastic \\
\hline & Q10.5 & Recycling Paper \\
\hline & Q10.6 & Reusing Plastic \\
\hline \multirow[t]{3}{*}{$\begin{array}{l}\text { Local Purchasing } \\
\alpha=.78\end{array}$} & Q11.1 & $\begin{array}{l}\text { Purchased locally produced foods when available from } \\
\text { distributor }\end{array}$ \\
\hline & Q11.2 & Purchased locally produced foods directly from sources \\
\hline & Q12.1 & $\begin{array}{l}\text { Plan menus with priority given to seasonal produce } \\
\text { availability }\end{array}$ \\
\hline \multirow{3}{*}{$\begin{array}{l}\text { Packaging } \\
\text { Reduction } \\
\alpha=.63\end{array}$} & Q10.8 & Reduce or less individual servings of drinks in bottles or cans \\
\hline & Q11.4 & Purchase bulk food products to reduce packaging waste \\
\hline & Q11.5 & $\begin{array}{l}\text { Purchase food products with reusable containers or returnable } \\
\text { totes. }\end{array}$ \\
\hline \multirow{5}{*}{$\begin{array}{l}\text { Contract Encourage } \\
\alpha=.94\end{array}$} & Q6A.1 & Supported in efforts to procure local products \\
\hline & Q6A.2 & Supported in efforts to use green clean products \\
\hline & Q6A.3 & Encouraged to promote awareness of local products \\
\hline & Q6A.4 & Encouraged to promote awareness of recycling, etc. \\
\hline & Q6A.5 & Encouraged to build partnerships with local producers \\
\hline \multirow{2}{*}{$\begin{array}{l}\text { Contract Require } \\
\rho=.88\end{array}$} & Q6A.6 & Required to report \% of local, sustainable, etc. \\
\hline & Q6A.7 & Required to meet established minimums of local food \\
\hline \multirow{3}{*}{$\begin{array}{l}\text { Contract Dominant } \\
\text { Supplier } \\
\alpha=.61\end{array}$} & Q5 & Discretion level over supplier selection \\
\hline & Q6.1 & Allowed to purchase from other suppliers without penalty \\
\hline & Q6.3 & Allowed to renegotiate contract flexibility to buy local foods \\
\hline \multirow{2}{*}{$\begin{array}{l}\text { Facility Flexibility } \\
\rho=.13\end{array}$} & Q7 & Level of food preparation facilities \\
\hline & Q8 & Level of food delivery format \\
\hline
\end{tabular}

\subsubsection{Regression models}

To test the proposed hypothesis, regression models were run for each type of policy construct (recycling practices, local purchasing, and packaging reduction) and the partner construct of percentage of waste reduced, percentage local product purchased, and percentage packaging reduced as the dependent variables. The independent variables were the relevant perception of host organization and end customers values related to that construct (specific practice and sustainability); the three contract constructs (encourage, require, and dominant supplier); the facility flexibility construct; and a variable for third-party contracted versus employee of host 
organization (buyer-supplier role). The results of the stepwise factor analysis are shown in Table 3.17 .

Table 3.17 Stepwise regression of policy formalization and outcomes as a function of values, contract, and facility flexibility

\begin{tabular}{|c|c|c|c|c|c|}
\hline \multicolumn{6}{|c|}{$\begin{array}{l}\text { Stepwise regression results of policy formalization and outcomes } \\
\text { as a function of values, contract, and facility flexibility }\end{array}$} \\
\hline & & $\mathbf{R}_{\text {adj }}^{2}$ & $\mathrm{~F}(\operatorname{sig})$ & $\begin{array}{l}\text { Significant Independent } \\
\text { Variables }\end{array}$ & $\begin{array}{l}\text { Standardized } \\
\quad \beta(p)\end{array}$ \\
\hline \multirow[t]{2}{*}{$\begin{array}{l}\text { Packaging } \\
\text { Waste } \\
\text { Reduction }\end{array}$} & $\begin{array}{l}\text { Policy } \\
\text { formalization }\end{array}$ & .258 & $\begin{array}{l}11.445 \\
(.000)\end{array}$ & $\begin{array}{l}\text { Host Value (packaging waste) } \\
\text { Buyer-Supplier Role } \\
\text { Contract Require }\end{array}$ & $\begin{array}{l}0.418(.000) \\
-.314(.007) \\
0.281(.022)\end{array}$ \\
\hline & \% Reduced & .102 & $\begin{array}{l}9.971 \\
(.000)\end{array}$ & Host Value (packaging waste) & $0.354(.025)$ \\
\hline \multirow[t]{2}{*}{$\begin{array}{l}\text { Packaging } \\
\text { Recycled }\end{array}$} & $\begin{array}{l}\text { Policy } \\
\text { formalization }\end{array}$ & .241 & $\begin{array}{l}10.67 \\
(.000)\end{array}$ & $\begin{array}{l}\text { End Customer Value } \\
\text { (sustainability) }\end{array}$ & $0.349(.005)$ \\
\hline & \% Recycled & .148 & $\begin{array}{l}9.33 \\
(.004)\end{array}$ & $\begin{array}{l}\text { Host Value } \\
\text { (sustainability) }\end{array}$ & $0.407(.004)$ \\
\hline \multirow[t]{2}{*}{$\begin{array}{l}\text { Local } \\
\text { Purchasing }\end{array}$} & $\begin{array}{l}\text { Policy } \\
\text { formalization }\end{array}$ & .445 & $\begin{array}{l}17.02 \\
(.000)\end{array}$ & $\begin{array}{l}\text { Contract Encourage } \\
\text { Buyer-Supplier Role }\end{array}$ & $\begin{array}{l}0.417(.000) \\
-.308(.002)\end{array}$ \\
\hline & $\%$ purchased & .379 & $\begin{array}{l}15.631 \\
(.000)\end{array}$ & $\begin{array}{l}\text { Host Value (local purchasing) } \\
\text { Buyer-Supplier Role }\end{array}$ & $\begin{array}{l}.297(.015) \\
-.490(.000)\end{array}$ \\
\hline
\end{tabular}

These results show some support for certain hypotheses. First, H1a, the relationship between host organization values and policy formalization, is supported for packaging waste policy. If the host organization sees packaging waste reduction as an important goal, then it is more likely that they have a formal policy in place. Additionally, in every case the host organization supporting values translate into more packaging waste reduction and recycling in terms of total waste generated and a higher percentage of local purchasing (fully supporting $\mathrm{H} 1 \mathrm{~b}$ ).

Second, the end customer values concerning sustainability, in general, do contribute to policy formalization for packaging recycling, but do not translate into any actual percentage reductions. Thus H2a is partially supported, while $\mathrm{H} 2 \mathrm{~b}$ is not supported for any values or outcomes.

Third, the use of third-party purchasing (contracted dining service) plays a positive role in both policy formalization and percentage waste reduced or local purchasing. While the direction of the relationship was not proposed in $\mathrm{H} 3$, it is clear that those organizations using contracted dining services have a more formalized policy on packaging waste reduction and local purchasing. This relationship leads to a higher percentage of local purchases. Thus, partial support for $\mathrm{H} 3 \mathrm{a}$ and $\mathrm{H} 3 \mathrm{~b}$ is evident.

Fourth, different aspects of the contract have an effect on outcomes. Contract reporting requirements which require purchasing individuals to meet established minimums or document percentages of products that are local or sustainable are related to formalized policies on waste 
reduction. Encouraging activities are also related to the level of policy formalization for local purchasing, but do not have a significant relationship with percentage improvements on any measures. In this case, $\mathrm{H} 4 \mathrm{a}$ is partially supported but $\mathrm{H} 4 \mathrm{~b}$ is not supported.

Finally, H5, the relationships between facility flexibility and either policy formalization level or percentages of improvement are not supported.

\subsection{CONCLUSIONS}

In this section, the institutional context, contracts, and facility flexibility are explored, and how these might relate to the policy formalization and performance outcomes related to local purchasing and waste reduction. The results show that the contracted dining services (third-party purchasing) and the host organization seem to be aligned in their perceptions of values related to packaging waste reduction and recycling, food waste reduction, and local purchasing. On the other hand, the respondents felt that their end customers were not as committed or supportive of these values except for local purchasing.

Because this study was asking about packaging waste, the purchasing group was probably more aware of the impact of this waste relative to the end customer. Many of the end consumers have no idea how their food arrived at the dining facility; thus, it becomes the responsibility of the host organization and its food service employees or contracted food service provider to manage the waste streams from the kitchen. The results show that high levels of host organization values around these waste issues translate into more formalized policies with goals and reporting requirements. These policies, in turn, do lead to improved performance.

While this study shows that all three potential groups (host organization, contracted dining service, and customer) are aligned in their values related to local product purchasing, according to the results the host organization's values on local purchasing drive the performance outcome. Typically, this value is conveyed through encouraging language to the purchasing person and formalized policy language with the third-party purchaser. It could be the case that those host organizations using third-party services are more likely to create contracts related to purchasing relative to the type of policy that might be provided to an in-house employee. This could be the explanation for more policy formalization when third parties are used and the resulting higher percentages of local purchasing.

Another interesting finding is the role of the end customer and host organization's support of sustainability in general. While the end customer's support appears to relate to higher policy formalization on packaging recycling, it is the host organization's support that leads to higher percentages of recycled packaging. Thus, the customer drives the policy in this case, but the host organization implements this policy.

Finally, the hypothesis relating the facility flexibility to policy formalization and performance outcomes was not supported. From the interview data, a respondent mentioned that not having a full kitchen or dining facility would limit purchasers to pre-processed foods, premade salads, etc., which can be challenging to control from a sustainable purchasing perspective. But, the sample showed $95 \%$ of respondents with full- or quick-service dining, and $94 \%$ had full kitchens and at least a simple bakery set-up. Thus, the sample could explain this finding. 


\subsection{LIFE-CYCLE EMISSIONS OF HIGH-VOLUME PRODUCTS ANALYSIS}

\subsection{INTRODUCTION}

Through surveys and interviews, the top purchased products and their packaging materials, the top food waste categories, and the top packaging waste categories were all identified. It was the purpose of this study to compare life-cycle carbon analysis for three very different product categories in order to determine impact of:

1. Alternative packaging choices

2. Food waste (raw and cooked): Zero waste, $50 \%$ waste before kitchen processing, and $50 \%$ waste after kitchen processing, with raw vegetables composted, and all cooked foods and meats sent to landfills.

3. Transportation effect: Resulting transportation impacts on the incoming food and outgoing waste products (packaging and food) based on local versus mainstream sourcing and alternative trucking requirements (non-refrigerated, refrigerated, and freezer trucks where relevant).

The final food categories were processed diced tomatoes, raw potatoes, and fresh or frozen chicken. Considerable details regarding the analysis are provided in this section, and additional details are provided in Appendix A-4.

\subsection{EXPERIMENTAL DESIGN DETAILS}

In this section, the assumptions used for each of the food categories and the experimental design are described.

\subsubsection{Processed diced tomatoes}

Canned tomatoes are one of the top grocery category food purchases for institutional users. These products are used for everything from pizza or pasta sauces to lasagna and other types of casseroles. Typically, these tomatoes are purchased in \#10 cans (also known as the 603x700) which contain 6.5 to $7.5 \mathrm{lbs}$ of product with six cans in a case. The typical can is $29 \%$ recycled post-consumer steel (Ball Containers 2009) and the finished can is recycled by most municipalities. One of the drawbacks of the canned product is the perishability rate after the can has been opened. Typically, the opened can should be used within three or four days; otherwise, the tomatoes must be thrown away.

As an alternative, the aseptic bag (PE clear barrier EVOH) with a nozzle can be used for processed tomatoes. Similar to wine in a box, the diced processed tomatoes are sealed in the airtight pouch. In this case, a three-liter bag holds the equivalent amount of tomatoes as a \#10 can (Rapak 2009). Eight bags can fit in the same case as above. The finished bag is not recyclable and must go to a landfill as waste. On the other hand, the aseptic bag typically lets very little oxygen into the bag when opened and has a much longer shelf life as an "unsealed" container. 
From the interview data, it would appear that the product can last two to three times longer in the partially used state relative to the can.

While neither packaging method influences the trucking choice (no refrigeration required), the potential amount of food waste could vary depending on the package. Additionally, many interviewees mentioned their unmet demand for local processed tomato products (within 100 miles). Instead, regardless of the institution's location, they would have to purchase these products from California.

Given these factors, an experimental design was developed with two package choices (can versus bag); two sourcing locations (local within 100 miles or major California producer); and three food waste scenarios (none, 50\% wasted before cooking, and 50\% wasted after cooking into a casserole). With a full factorial design, this resulted in $2 \times 2 \times 3$ or 12 scenarios.

\subsubsection{Fresh potatoes}

Fresh potatoes are one of the highest-volume produce items used by institutional purchasers, as noted in the interviews and surveys. While potatoes do have a fairly robust shelf life, they are perishable and typically must be used within two months. Because they are perceived to be relatively cheap, kitchens tend to over-forecast potato use rather than carefully control portioning. Once cut into pieces, for French or home fries, the cut potato pieces turn grey or black. Thus, the potatoes must be cooked quickly, and then face the risk of becoming cooked food waste (landfill material) rather than uncooked waste (composted). For the experimental design, the no-waste scenario was considered; $50 \%$ of the potatoes wasted before cooking (and thrown into compost); and $50 \%$ of the potatoes wasted after cooking (and thrown into the landfill).

Typically, fresh potatoes are purchased in corrugated cardboard boxes which each hold 40 pounds. This box is recycled after one use. A newer fresh produce delivery option is the reusable plastic container (RPC). Composed of Polypropylene \#7, the RPC is returned to the local produce distributor, where it is washed and put back into use for a seven- to 10-year life. After the RPC wears out, it is reground and made into new containers. In a recent study of RPCs and average condition produce shipping (Franklin Associates 2004), the researchers found that on average, across 10 produce applications, RPCS required 39\% less total energy, produced $95 \%$ less total solid waste, and generated $29 \%$ less total greenhouse gas emissions. Thus, the RPC is an appropriate choice to compare against the standard recyclable cardboard box.

Finally, the option of purchasing the potatoes from a local produce supplier (within 100 miles) and from the mainstream Oregon/Idaho suppliers was considered. Given these factors, an experimental design with two package choices (box versus RPC); two sourcing locations (local within 100 miles or major Oregon/Idaho producer); and three food waste scenarios (none, 50\% wasted before cooking, and 50\% wasted after cooking into a casserole) was developed. With a full factorial design, this resulted in $2 \times 2 \times 3$ or 12 scenarios. 


\subsubsection{Chicken}

From the interview and survey results, chicken was the most popular meat item for institutional purchases. Chicken was typically purchased as a frozen or fresh product, which had significant implications for food waste. Fresh chicken has a very limited shelf life (four to five days) and must be kept refrigerated; frozen chicken can last many months in the freezer and only the required pieces need to be thawed in preparation for a meal. Thus, fresh chicken requires very precise ordering and portion control to limit food waste.

Both fresh and frozen chicken are purchased in cardboard boxes with different types of polyethylene bags. Fresh chicken typically uses more bags; often, each chicken is bagged individually and then six chickens are bagged together. The frozen chicken has 10 pounds of chicken in each bag.

This section of the study focused on two transportation-related purchasing decisions: the buy local and fresh (production location within 100 miles), and buy frozen from the national broadline distributor with a central U.S. location. Given these factors, an experimental design with specific package depending on if it is fresh or frozen chicken was developed; specific sourcing locations (fresh is local within 100 miles and frozen is a major U.S. mid-western producer); and three food waste scenarios (none, 50\% wasted before cooking, and 50\% wasted after cooking into a casserole). With a full factorial design, this resulted in $2 \times 3$ or 6 scenarios.

\subsection{LIFE-CYCLE CARBON ASSESSMENT METHOD}

The analysis determined the amount of "embodied carbon," which is an alternative way to refer to the carbon footprint of a product within a specified system boundary. It is the total greenhouse gas emissions generated by the product life cycle within a system boundary of interest and reported in $\mathrm{Kg}$ of $\mathrm{CO}_{2}$ equivalents (that is, $\mathrm{Kg}$ of $\mathrm{CO}_{2}$ per $\mathrm{Kg}$ of product).

\subsubsection{Tools, data sources, and standards}

The analytical tool employed is called CarbonScope (Venkat 2008). The life-cycle inventory (LCI) data regarding the carbon content of agricultural production, packaging materials, energy use for transport, etc. was provided by Cleanmetrics, LLC (Venkat 2008). More details of the LCI methodology employed are also available (Venkat 2008).

California agricultural data was available for tomatoes and potatoes, and this same data was assumed to be valid for local production in Oregon. The data available for chicken production is from Denmark, and this data was assumed to be a suitable proxy for U.S. production. While the data is for "chicken meat," it is assumed to be a suitable proxy for the production of whole chicken.

Cooking was analyzed using standard restaurant equipment, a gas convection oven, a gas restaurant range, and a steam table. For electricity, emission factors for the Oregon power grid were utilized. Additional details may be found in Appendix A-4. 
The primary standard used for the product life-cycle GHG emissions calculations was PAS 2050 (BSI Group 2008). PAS 2050 in turn relies on the ISO 14040 series of standards (International Organization for Standardization 2000) and the 2006 IPCC Guidelines for National Greenhouse Gas Inventories (Intergovernmental Panel on Climate Change 2006).

\subsubsection{Analysis boundary and assumptions}

The analysis considered the full product life-cycle, including agricultural production, initial processing and packaging, transport to the institutional kitchen, cooking, and waste disposal.

For product discarded, either before or after cooking, the amount consumed was not changed. Rather, the accumulated embodied carbon at the waste point was factored upward by the percentage of waste assumed for that given scenario. Composted food waste is assumed to generate negligible amounts of methane. Further, all $\mathrm{CO} 2$ from composting is of biogenic origin and therefore considered not to be a contributor to global warming. Landfilled plastic packaging materials are assumed not to contain readily degradable organic carbon, and therefore do not contribute to global warming within a 100-year assessment period.

Landfilled food waste generates significant amounts of methane, which are therefore included in the product's life-cycle embodied carbon. Landfill methane emissions are modeled based on IPCC guidelines, with a weighted average computed over a 100-year assessment period per the PAS 2050 standard, under the following conditions: Temperate/wet climate zone, no oxidation of methane in the soil or covering; assume $50 \%$ of landfill gas is methane, and $25 \%$ of methane is recovered and combusted as fuel.

All recycling was assumed to be open-loop, even though recycled materials used in packaging may originate from the same product system (closed-loop) because it is more likely that they originated from different product systems (open-loop). Appropriate credit is given (by way of lower embodied carbon) for the recycled content of materials used in packaging. No credit is given for "used" packaging materials which are then also recycled after use (in order to avoid double counting the benefits of recycling).

\subsection{LIFE-CYCLE CARBON ASSESSMENT RESULTS}

Given the 30 scenarios discussed above, a complete Life-cycle Carbon Assessment was done for each scenario using the assumptions provided in Appendix A-4. The results are shown in Table 4.1. 
Table 4.1 Life-cycle carbon assessment results for transportation, packaging, and waste alternatives (normalized embodied carbon, $\mathrm{kg} \mathrm{CO}_{2} / \mathrm{kg}$ )

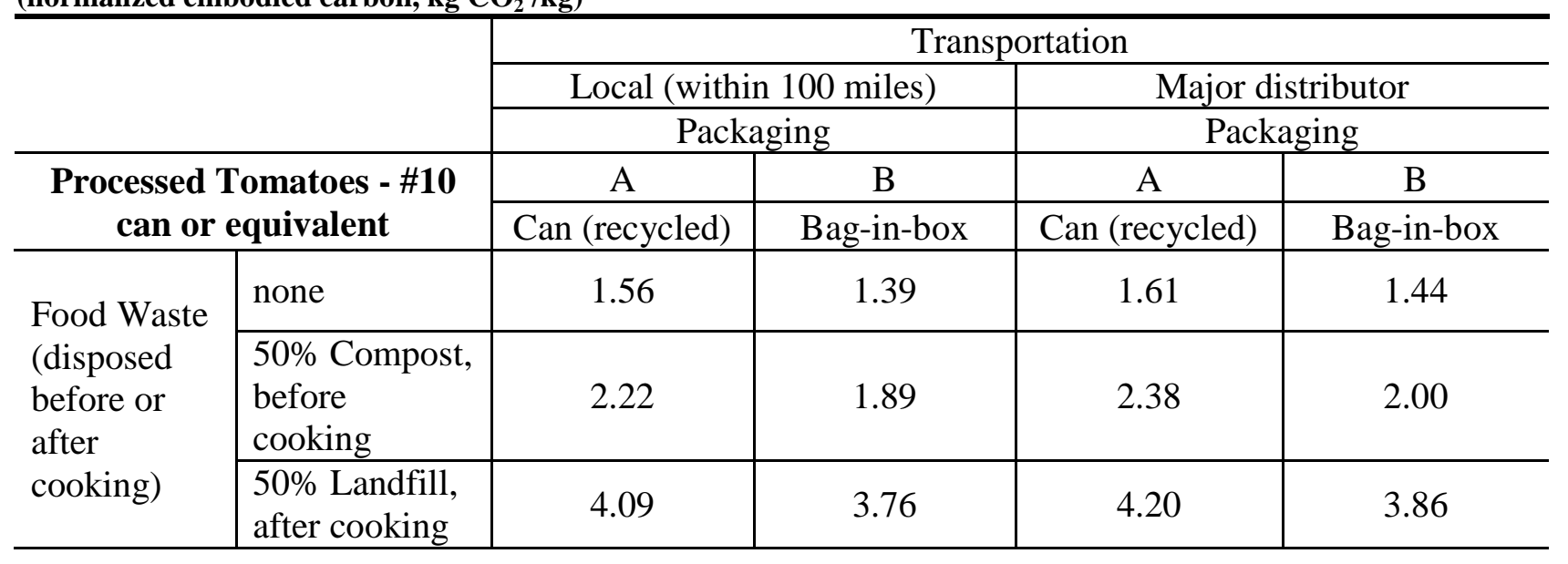

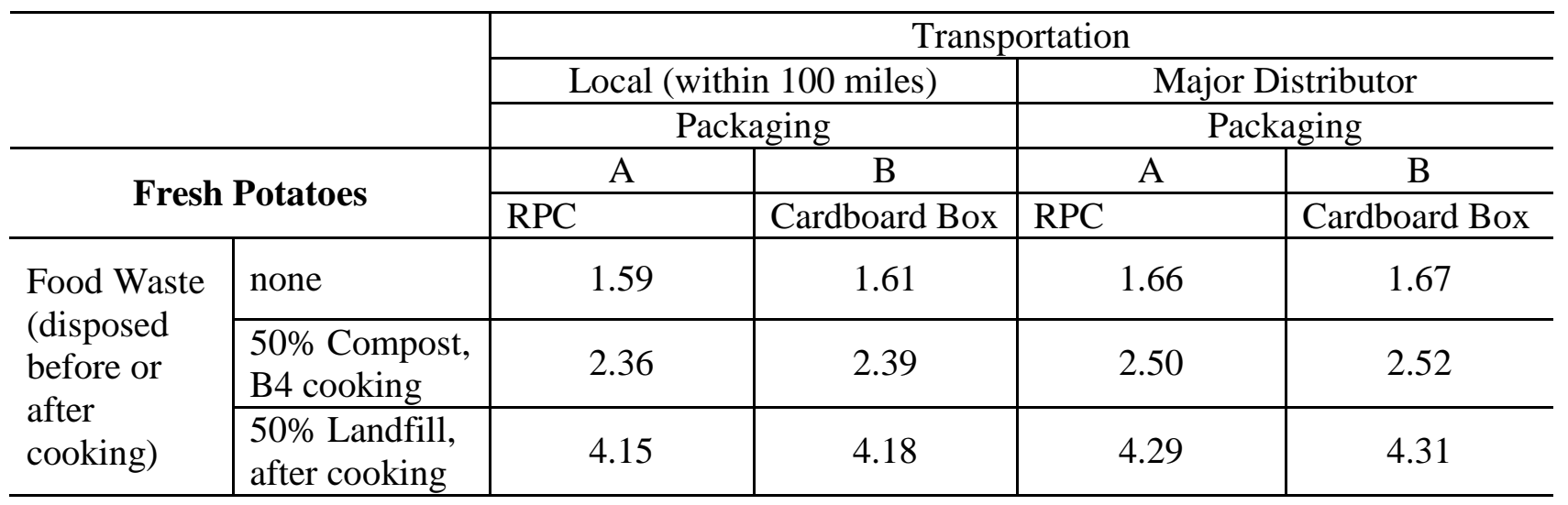

Transportation

\begin{tabular}{|c|c|c|c|}
\hline & \multicolumn{2}{|c|}{ Transportation } \\
\hline & & Fresh Local (within 100 miles) & Frozen (major distributor) \\
\hline & & Packaging & Packaging \\
\hline \multirow{2}{*}{\multicolumn{2}{|c|}{ Chicken - 10 lb Box }} & $\mathrm{A}$ & $\mathrm{B}$ \\
\hline & & $\begin{array}{c}12 \text { birds, two bags, plastic liner, } \\
\text { box }\end{array}$ & $\begin{array}{c}\text { 24-36 count Hard Plastic Liner } \\
\text { Trays \& Cardboard box }\end{array}$ \\
\hline \multirow{3}{*}{$\begin{array}{l}\text { Food Waste } \\
\text { (disposed } \\
\text { before or } \\
\text { after } \\
\text { cooking) }\end{array}$} & none & 3.54 & 4.14 \\
\hline & $\begin{array}{l}\text { 50\% Landfill, } \\
\text { B4 cooking }\end{array}$ & 7.16 & 8.16 \\
\hline & $\begin{array}{l}50 \% \text { Landfill, } \\
\text { after cooking }\end{array}$ & 8.16 & 9.36 \\
\hline
\end{tabular}




\subsubsection{Processed tomato results}

The processed tomato results for packaging LCC analysis show a consistent advantage for bagged over canned product, saving on average $.28 \mathrm{~kg} \mathrm{CO}_{2} / \mathrm{kg}$. Comparing local versus major distributor (California) for similar waste scenarios and packaging types, local purchasing saved on average $.09 \mathrm{~kg} \mathrm{CO}_{2} / \mathrm{kg}$. For metal cans, comparing no food waste versus wasted before cooking shows a $.71 \mathrm{~kg} \mathrm{CO} / \mathrm{kg}$ average advantage for no waste and $1.845 \mathrm{~kg} \mathrm{CO}_{2} / \mathrm{kg}$ average advantage for throwing away before versus after cooking. Similarly, for the plastic packaging, comparing no food waste versus wasted before cooking shows a $.53 \mathrm{~kg} \mathrm{CO}_{2} / \mathrm{kg}$ average advantage for no waste and $1.86 \mathrm{~kg} \mathrm{CO}_{2} / \mathrm{kg}$ average advantage for throwing away before versus after cooking.

\subsubsection{Fresh potato results}

RPC packed potatoes show a very small advantage over those packed in cardboard boxes $(.02 \mathrm{~kg}$ $\mathrm{CO}_{2} / \mathrm{kg}$ average). Looking at the impact of purchasing locally (within 100 miles) versus from a national distributor, local purchasing has a $.11 \mathrm{~kg} \mathrm{CO}_{2} / \mathrm{kg}$ average advantage. Looking at the food waste scenarios, no food waste saves $.81 \mathrm{~kg} \mathrm{CO}_{2} / \mathrm{kg}$ average over the $50 \%$ thrown out before cooking and $1.70 \mathrm{~kg} \mathrm{CO}_{2} / \mathrm{kg}$ average advantage for throwing out before cooking versus after cooking. Here the packaging has very little effect on either the food waste or transportation LCC.

\subsubsection{Chicken results}

Purchasing local fresh chicken has a LCC advantage over nationally distributed frozen chicken $(.933 \mathrm{~kg} \mathrm{CO} / \mathrm{kg})$. The no-waste chicken scenarios have a $3.82 \mathrm{~kg} \mathrm{CO}_{2} / \mathrm{kg}$ advantage over throwing away $50 \%$ of the chicken before cooking. Throwing away the same quantity of chicken after cooking versus before cooking adds $1.1 \mathrm{~kg} \mathrm{CO}_{2} / \mathrm{kg}$ to the remaining product.

\subsection{LIFE-CYCLE CARBON ASSESSMENT DISCUSSION}

The results of the LCC analysis highlight several interesting patterns. Clearly, chicken as a category has the most carbon emissions per kilogram, followed by fresh potatoes and then processed tomatoes. Second, the biggest LCC reductions appear to come from not wasting cooked food. In every category, the largest impacts come from this source. Although chicken in its frozen form is considered to be easier to control (in terms of perishability), controlling the amount of wasted cooked chicken is the bigger issue.

For this particular research, the potatoes using RPC packaging had a minimal advantage over cardboard boxes. These results do not show the same large improvements found in other produce categories in LCC research by Franklin Associates (2004). In this particular research, potatoes are sourced in the northwestern U.S. so that the difference between a local grower and national distribution source are not large relative to the chicken or tomatoes. Thus, it is possible that RPC could have a more significant advantage is environments with longer transportation distances. 
The aseptic plastic bag packaging did prove to be the best LCC solution even though the bag ends up in the landfill. And if using bag packaging contributes to less food waste, then it handily beats out the steel can by almost $100 \%$ improvement per kilogram. In fact, it is better to buy a bag-packaged product from California rather than a local canned product.

In all cases, purchasing local food had advantages over nationally distributed food. This was particularly advantageous for chicken and less so for the processed tomatoes.

\subsection{LIFE-CYCLE CARBON ASSESSMENT CONCLUSION}

Interpreting these results suggests that food waste has a large adverse impact on the environment, especially if landfilled, as with cooked vegetables (typically) and meats. Even composted raw vegetables significantly increase carbon impact. Packaging efforts that contribute to the reduction of food waste (both before and after cooking) would appear to be a wise direction for institutional policy. Similarly, the buy-local efforts for the three most popular category products do make sense and contribute to some carbon reductions, but transportation-related carbon impacts were more significant for frozen meat items.

Overall, "food miles" do not matter as much as other considerations when determining the climate impact of food production, consumption, and disposal (except perhaps fresh food that is air freighted). Minimizing food waste and composting the unavoidable food waste could have a much larger benefit than switching from a distant supplier to a local supplier. Also, when analyzed carefully, one must conclude that plastic packaging generally has a smaller environmental footprint than steel, paper, or glass due to its low usage volumes and weight. 



\subsection{CONCLUSION}

This study used a multi-method approach to look at the policies, practices, and outcomes associated with sustainability issues in institutional purchasing. This study particularly focused on the choices that purchasers make around buying local versus nationally distributed products, and the associated food and packaging wastes. This study explored what drives institutional policy around these topics, the level of implementation of different sustainability policies, and the resulting waste reduction. In the process, data was also collected on the highest-volume purchased food categories. From the data analysis, three diverse food categories were selected to explore the LCC assessment from a number of scenarios to evaluate current best practices in packaging (RPC for produce and aseptic packaging); purchasing local versus nationally produced products; shipping fresh versus frozen meats; and evaluating different process points for food waste.

Our initial interviews revealed that that any efforts related to purchasing food products from closer locations (i.e., local food) and waste reduction efforts must happen in a cost-effective way. Thus, packaging improvements, processing type, and transportation method should contribute to food waste reduction to address the needs of the institutional purchasing group's drivers and focus. Similarly, the LCC analysis shows that efforts to reduce food and packaging waste (by volume or weight) will have the biggest impact on emission reduction. This would imply that the institutional kitchen manager should work with the purchasing entity to choose packaging options that help to control food waste and packaging waste simultaneously.

The initial interviews revealed key institution and supply chain structures that potentially contribute to the feasibility of changes to existing purchasing practices. In particular, the alignment of the institution's policies with the rest of the triad (third-party food service and dominant distributor) would appear to affect the practices adopted by the institution and resulting increases in local food purchasing and reductions of waste streams.

This interview information was used to craft a pilot survey to further explore the above topics and determine the biggest food purchase items and waste policies and outcomes. This study found that while food quality was the highest priority, respondents did believe that their food purchasing organizations and end customers were committed to sustainable purchasing. Respondents also indicated that, on average, they had a lot of discretion on their choice of supplier. However, most respondents purchased the majority of their food from national suppliers, and saw the most serious obstacle of adopting sustainable food purchasing to be lack of infrastructure for sustainable suppliers.

When it came to packaging waste reduction, respondents saw uneconomic reusing of packaging as the most serious obstacle. Despite obstacles in reusing packaging, cardboard and paper, glass, metal cans, hard plastic, and soft plastic all had high recycling rates (above 75\%) with respondents who had recycling programs. Based on the pilot survey results, the high-volume foods and packaging alternatives for the life-cycle analysis could be chosen with confidence. 
The pilot survey was refined into a shorter version with focused questions about institutional context; institution, purchasing group and customer alignment; and resulting policies and practices. The results show that the contracted dining services (third-party purchasing) and the host organization seem to be aligned in their perceptions of values related to packaging waste reduction and recycling, food waste reduction, and local purchasing. On the other hand, the respondents felt that their end customers are not as committed or supportive of these values except for local purchasing.

Because the survey instrument asked about packaging waste, the purchasing group is probably more aware of the impact of this waste relative to the end customer. Many of the end consumers have no idea how their food arrived at the dining facility. Thus, it becomes the responsibility of the host organization and its food service employees or contracted food service provider to manage the waste streams from the kitchen. The results show that high levels of host organization values around these waste issues translate into more formalized policies with goals and reporting requirements. These policies, in turn, do lead to improved performance.

While the study shows that all three potential groups (host organization, contracted dining service, and end customer) are aligned in their values related to local product purchasing, according to the results, the host's values on local purchasing drives the performance outcome. Typically, this value is conveyed through encouraging language to the purchasing person and formalized policy language with the third-party purchaser. It could be the case that those host organizations using third-party services are more likely to create contracts related to purchasing relative to the type of policy that might be provided to an in-house employee. This could be the explanation for more policy formalization when third parties are used and the resulting higher percentages of local purchasing.

Another interesting finding is the role of the end customer and host organization's support of sustainability in general. While the end customer's support appears to relate to higher policy formalization on packaging recycling, it is the host organization's support that leads to higher percentages of recycled packaging. Thus, the customer drives the policy in this case, but the host organization implements this policy.

Finally, the LCC results were analyzed for the three most popular food products and multiple scenarios that tie into the aforementioned purchasing policies and practices. The biggest finding suggests that food waste has a large adverse impact on the environment; even composted raw vegetables significantly increase carbon impact. Packaging efforts that contribute to the reduction of food waste (both before and after cooking) would appear to be a wise direction for institutional policy. Similarly, the buy-local efforts for the three most popular category products do make sense and contribute to some carbon reductions, but transportation-related carbon impacts were more significant for frozen meat items.

Overall, this research suggests that much of the current sustainable food purchasing policy is not tackling the "low-hanging" fruit. End customers appear to be driving much of the policy, but are largely unaware of the huge impacts of things like packaging (outside of the dining space) and food waste. Minimizing food waste and composting the unavoidable food waste could have a much larger benefit than switching from a distant supplier to a local supplier. Also, most institutions did not have a policy to reduce the consumption of animal products, and the chicken 
LCC was considerably higher than either of the other food products. This finding shows the need for education and policy on measuring the impact of all food purchasing decisions and including product type, packaging choice, and food waste levels. 


\section{REFERENCES}

Ball Containers. 2009. Ball Containers Cans by Size 2009 [cited March 18 2009]. Available from http://www.ballamericas.com/page.jsp?page $=50$.

Bartlett, Paul A., Denyse M. Julien, and Tim S. Baines. 2007. Improving supply chain performance through improved visibility. The International Journal of Logistics Management 18 (2):294-313.

Bauccio, Fedele, and Brian Halwell. 2005. Bon Appetit accounts get local in challenge. FoodService Director 18 (11):16.

BSI Group. 2009. PAS 2050:2008 - Specification for the assessment of the lifecycle greenhouse gas emissions of goods and services. BSI Group 2008 [cited March 18 2009]. Available from http://www.bsigroup.com/en/Standards-and-Publications/Industry-Sectors/Energy/PAS-2050/.

Corbin, Juliet M., and Anselm L. Strauss. 1998. Basics of Qualitative Research: Techniques and Procedures for Developing Grounded Theory. Second ed. Thousand Oaks, CA: Sage Publications.

Corbin, Juliet, and Anselm L. Strauss. 1998. Basics of Qualitative Research: Techniques and Procedures for Developing Grounded Theory. Second ed. Thousand Oaks, CA: Sage Publications.

Creswell, John W. 1998. Qualitative Inquiry and Research Design: Choosing Among Five Traditions. Thousand Oaks, CA: Sage.

Fawcett, Stanley E., Gregory M. Magnan, and Matthew W. McCarter. 2008. Benefits, barriers, and bridges to effective supply chain management. The International Journal of Logistics Management 18 (2):294-313.

Finney, Joanne. 2006. Going the distance. Food Manufacture 81 (7):17.

Franklin Associates. 2009. Final Draft Executive Summary for Life Cycle Inventory of Reusable Plastic Containers and Display-Ready Corrugated Containers used for Fresh Produce Applications. Reusable Pallet \& Container Coalition 2004 [cited March 19 2009]. Available from http://www.choosereusables.org/images/Franklin_LCI_Study_-_Executive_Summary.pdf. 
Giannakis, Mihalis. 2007. Performance measurement of supplier relationships. Supply Chain Management: An International Journal 12 (6):400-411.

Glaser, Barney G., and Anselm L. Strauss. 1967. The Discovery of Grounded Theory; Strategies for Qualitative Research, Observations. Chicago,: Aldine Pub. Co.

Hair, Joseph F., William C. Black, Barry J. Babin, and Rolph E. Anderson. 2009. Multivariate Data Analysis. 7th ed. Saddle River, NJ: Prentice Hall.

Horrigan, Leo, Robert S. Lawrence, and Polly Walker. 2002. How Sustainable Agriculture Can Address the Environmental and Human

Health Harms of Industrial Agriculture. Environ Health Perspective 110:445-456.

Intergovernmental Panel on Climate Change. 2009. 2006 IPCC Guidelines for National Greenhouse Gas Inventories [pdf] 2006 [cited March 18 2009]. Available from http://www.ipcc-nggip.iges.or.jp/public/2006gl/index.html.

International Organization for Standardization. 2009. ISO 14040:2006 Environmental management --Life cycle assessment--Principles and framework (2) [pdf]. International Organization for Standardization 2000 [cited March 18 2009]. Available from http://www.iso.org/iso/iso_catalogue/catalogue_tc/catalogue_detail.htm?csnumber=37456.

Lamming, Richard, Nigel Caldwell, and Deborah Harrison. 2004. Developing the Concept of Transparency for Use in Supply Relationships. British Journal of Management 15:291-302.

Lee, Chang Won, Ik-Whan G. Kwon, and Dennis Severance. 2007. Relationship between supply chain performance and degree of linkage among supplier, internal integration, and customer. Supply Chain Management: An International Journal 12 (6):444-452.

Lindlof, Thomas R., and Bryan Copeland Taylor. 1995. Qualitative Communication Research Methods. Thousand Oaks, CA: Sage Publications.

Miles, Matthew B., and Michael Huberman. 1994. Qualitative Data Analysis: An Expanded Sourcebook. Second ed. Thousand Oaks, CA: Sage Publications.

Min, Hokey, and William P. Galle. 2001. Green purchasing practices of US firms. International Journal of Operations \& Production Management 21 (9):1222-1238. 
Piercy, Nigel F., and Nikala Lane. 2006. Ethical and Moral Dilemmas Associated with Strategic Relationships between Business-to-Business Buyers and Sellers. Journal of Business Ethics 72:87-102.

Pirog, Rich. 2004. Food Miles: A Simple Metaphor to Contrast Local and Global Food Systems. Hunger and Environmental Nutrition (HEN) Dietetic Practice Group of the American Dietetic Association.

Pirog, Rich, and Andrew Benjamin. 2008. Calculating food miles for a multiple ingredient food product. Leopold Center for Sustainable Agriculture. 2005 [cited July 11 2008]. Available from http://www.leopold.iastate.edu/pubs/staff/files/foodmiles_030305.pdf.

Rábade, Luis Arturo, and Jose Antonio Alfaro. 2006. Buyer-supplier relationship's influence on traceability implementation in the vegetable industry. Journal of Purchasing \& Supply Management 12:39-50.

Rapak. 2009. Rapak is the world's leading supplier of bag-in-box packaging and filling systems 2009 [cited March 18 2009]. Available from http://www.rapak.com/bags.asp?ACTRED=1.

Tukker, Arnold. 2006. Identifying Priorities for Environmental Product Policy. Journal of Industrial ecology 10 (3):1-4.

Venkat, Kumar. 2009. Carbonscope [Web-based Software Tool]. CleanMetrics 2008 [cited March 18 2009]. Available from http://www.cleanmetrics.com/html/carbonscope.htm.

- 2009. CarbonScopeData [Database]. CleanMetrics 2008 [cited March 18 2009]. Available from http://www.cleanmetrics.com/html/database.htm.

2009. Life Cycle Inventory Methodology and Data Sources. CleanMetrics 2008 [cited March 18 2009]. Available from http://www.cleanmetrics.com/html/lci_methodology.htm. 


\section{APPENDIX A-1}

\section{INTERVIEW PROTOCOL}

\section{Objectives}

To understand which sustainability issues concern food purchasers.

To examine current policies, standards, and measures for footprint and other sustainable issues in purchasing.

To examine problems and current obstacles in implementing footprint/sustainable policies.

\section{Demographics}

Who do they work for?

Meals served per day?

\section{General Issues}

Can you tell me what sustainability issues are addressed in your purchasing activities and policies? Please provide a specific instance that shows each of these.

Do you have formal policy documents that you would be willing to share with me?

Do you have a requirement for a yearly report with goals?

How long has your institution been concerned with sustainability issues? What has been the primary driver for action? Please provide an example of an early action that showed that concern.

Overall, what are the tangible and intangible impacts? How do you measure these impacts?

What departments are concerned/involved with these food purchasing issues?

What $\%$ of your time is spent on these purchasing issues related to sustainability activities?

What is your personal influence on the selection of suppliers? When choosing suppliers, how influential are you in choosing suppliers with appropriate sustainability characteristics? What specific criteria are used, in what priority, to choose among suppliers with different footprint characteristics?

Are your company's sustainability efforts publicized or marketed? In what way?

How do you identify and prioritize sustainability issues? What role do the customers and staff play in this process?

What are your sources of sustainability information? How much time and money is spent in understanding the information? How important are third-party certifications, self-declared attributes, etc.?

What trends will affect your purchasing policies in the future? 


\section{Purchasing}

Which products are used in the greatest volume? Type of transportation, packaging, and estimate of distance traveled?

What waste streams are generated by the types of food products purchased? Biggest problem areas?

Please comment on non-packaging waste, packaging waste, and reduce, reuse, and recycling aspects of packaging.

What considerations are taken into account for consumer packaging versus distribution and storage packaging?

Have any processes been redesigned to reduce/reclaim/reuse this waste?

How much control does your company have over the characteristics of the incoming products in terms of packaging type, volume, and food miles traveled?

What types of products do you have the most difficultly reducing the overall footprint impact (sustainability, food miles)?

What types of measures are gathered on the purchased food products (cost, method of transport, ability to reclaim, recycle, etc)?

\section{Business model, government regulations, third-party certification}

How does your business model or contract affect your ability to implement sustainable purchasing practices?

Are there currently any business incentives encouraging or requiring you to pursue sustainable purchasing practices? Do you anticipate any in the future? 


\section{APPENDIX A-2}

\section{PILOT SURVEY INSTRUMENT}

A pilot survey instrument was developed to collect in-depth data on industrial purchasing behavior regarding packaging and waste, food miles, and other sustainable purchasing issues. The survey instrument is summarized in the following paragraphs.

- Demographic questions regarding size of organization and buyer-supplier relationship (two questions).

- Respondent's priorities in purchasing decisions, ranking seven possible priorities (one question).

- Respondent's priorities in purchasing decisions within their particular purchasing environment (two questions); using a seven-point scale of agreement, four statements are given about sustainable purchasing, and respondents are asked about the priority of each of these statements for either

○ their end customer group or

$\circ$ their purchasing organization.

- Buyer-supplier relationship (Rábade and Alfaro 2006). Many purchasers have contracts with their supplier that significantly limits the amount and volume of items they can purchase from other suppliers (four questions).

- What is the diversity of the respondent's suppliers?

- How much discretion does the respondent have regarding suppliers choice?

$\circ$ On five-point scale, measure the seriousness of

- nine obstacles to sustainable purchasing and

- nine obstacles to reducing food packaging waste (Min and Galle 2001).

- Purchasing processed foods (four questions)

$\circ$ Amount and types of processed foods purchased.

- Facilities for processing foods on-site.

- Volume of food that is purchased that has sustainable characteristics,

- third-party certified or

- locally grown and processed.

- Assessing packaging and food waste reduction programs for 10 different types of packaging or food waste, and percent reduced if program is implemented (one question).

- Product mix and packaging characteristics

○ Identify most purchased food product from each category: Baked Goods, Dairy, Meat, Fruits, and Vegetables (two questions).

- Level of bulk packaging (one question for each category)

- Volume purchased (one question for each category)

- Level and type of processing (one question for each category)

○ Type of packaging (one question for each category) 
For this survey, we are assuming that you are a Food Purchaser for an institution such as a school or hospital. The Host Organization refers to the organization that owns the entire food manufacturing/production facility including the dining organization (a school or hospital)

The Food Purchasing Organization refers to the organization that employs you, the purchaser (often an independent contractor)

The End Customers are the group of people consuming the food and beverages (employees, guests, students, patients, etc.)

The term "sustainability" refers to using, developing and protecting resources in a manner that enables people to meet current needs while providing that future generations can also meet their needs from the joint perspective of environmental, economic and community objectives. Some examples of how sustainability practices are interpreted for the food industry include:

- Purchasing or handling food products from local growers or ranchers

- Providing safe and fair working conditions in the facility

- Providing healthy and humane care for animals (dairy or meat handlers)

- Eliminating the use of hormones and antibiotics (dairy or meat handlers)

- Eliminating the use of genetically modified organisms (GMO) in crops or livestock

- Reducing pesticide usage and toxicity

- Conserving energy and water resources in the facility and reducing polluting emissions

- Protecting and enhancing wildlife habitat affected by the facility such as rainwater runoff, riparian areas

- Protecting and enhancing soil resources on farm and ranch land

If you would like to refresh your memory during the survey, just scroll over "sustainability" or "sustainable" when it's mentioned in the text, and the definition will pop up. 


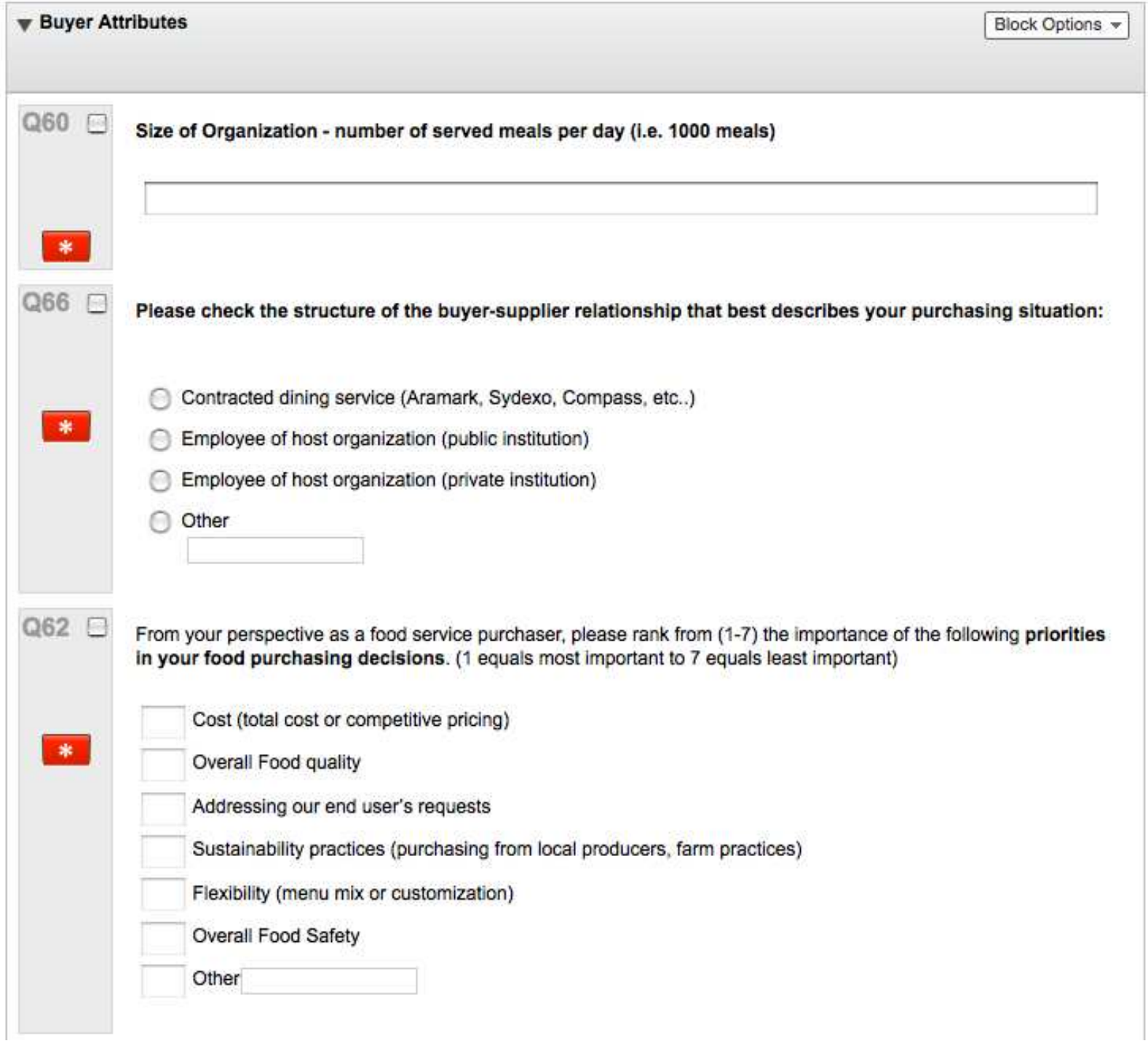


The Food Purchasing Organization refers to the organization that employs you, the purchaser (often an independent contractor)

Please indicate your level of agreement with the following statements regarding purchasing practices: "My Food Purchasing Group..."

\begin{tabular}{|c|c|c|c|c|c|c|c|}
\hline & $\begin{array}{c}\text { Strongly } \\
\text { Disagree } \\
1\end{array}$ & 2 & 3 & $\begin{array}{c}\text { Neither } \\
\text { Agree } \\
\text { nor } \\
\text { Disagree } \\
4\end{array}$ & 5 & 6 & $\begin{array}{l}\text { Strongly } \\
\text { Agree - } \\
7\end{array}$ \\
\hline $\begin{array}{l}\text { is fully committed to sustainable purchasing } \\
\text { practices. }\end{array}$ & 0 & 0 & 0 & 0 & 0 & ( & 0 \\
\hline $\begin{array}{l}\text { encourages purchases of local products } \\
\text { whenever possible. }\end{array}$ & 0 & 0 & 0 & 0 & 0 & 0 & 0 \\
\hline $\begin{array}{l}\text { sees packaging waste reduction as an } \\
\text { important goal. }\end{array}$ & 0 & 0 & 0 & 0 & 0 & 0 & 0 \\
\hline $\begin{array}{l}\text { sees food waste reduction as an important } \\
\text { goal. }\end{array}$ & 0 & 0 & 0 & 0 & 0 & (ㄱ) & 0 \\
\hline
\end{tabular}

The End Customers are the group of people consuming the food and beverages (employees, guests, students, patients, etc.)

Please indicate your level of agreement with the following statements regarding purchasing practices: "My End

Customer Group..."

\begin{tabular}{|c|c|c|c|c|c|c|c|}
\hline & $\begin{array}{c}\text { Strongly } \\
\text { Disagree } \\
1\end{array}$ & 2 & 3 & $\begin{array}{c}\text { Neither } \\
\text { Agree } \\
\text { nor } \\
\text { Disagree } \\
4\end{array}$ & 5 & 6 & $\begin{array}{c}\text { Strongly } \\
\text { Agree - } \\
7\end{array}$ \\
\hline $\begin{array}{l}\text { is fully committed to sustainable purchasing } \\
\text { practices. }\end{array}$ & 0 & 0 & 0 & 0 & 0 & 0 & 0 \\
\hline $\begin{array}{l}\text { encourages purchases of local products } \\
\text { whenever possible. }\end{array}$ & 0 & 0 & 0 & 0 & 0 & 0 & 0 \\
\hline $\begin{array}{l}\text { sees packaging waste reduction as an } \\
\text { important goal. }\end{array}$ & 0 & 0 & 0 & 0 & 0 & 0 & 0 \\
\hline $\begin{array}{l}\text { sees food waste reduction as an important } \\
\text { goal. }\end{array}$ & 0 & 0 & 0 & 0 & 0 & 0 & 0 \\
\hline
\end{tabular}




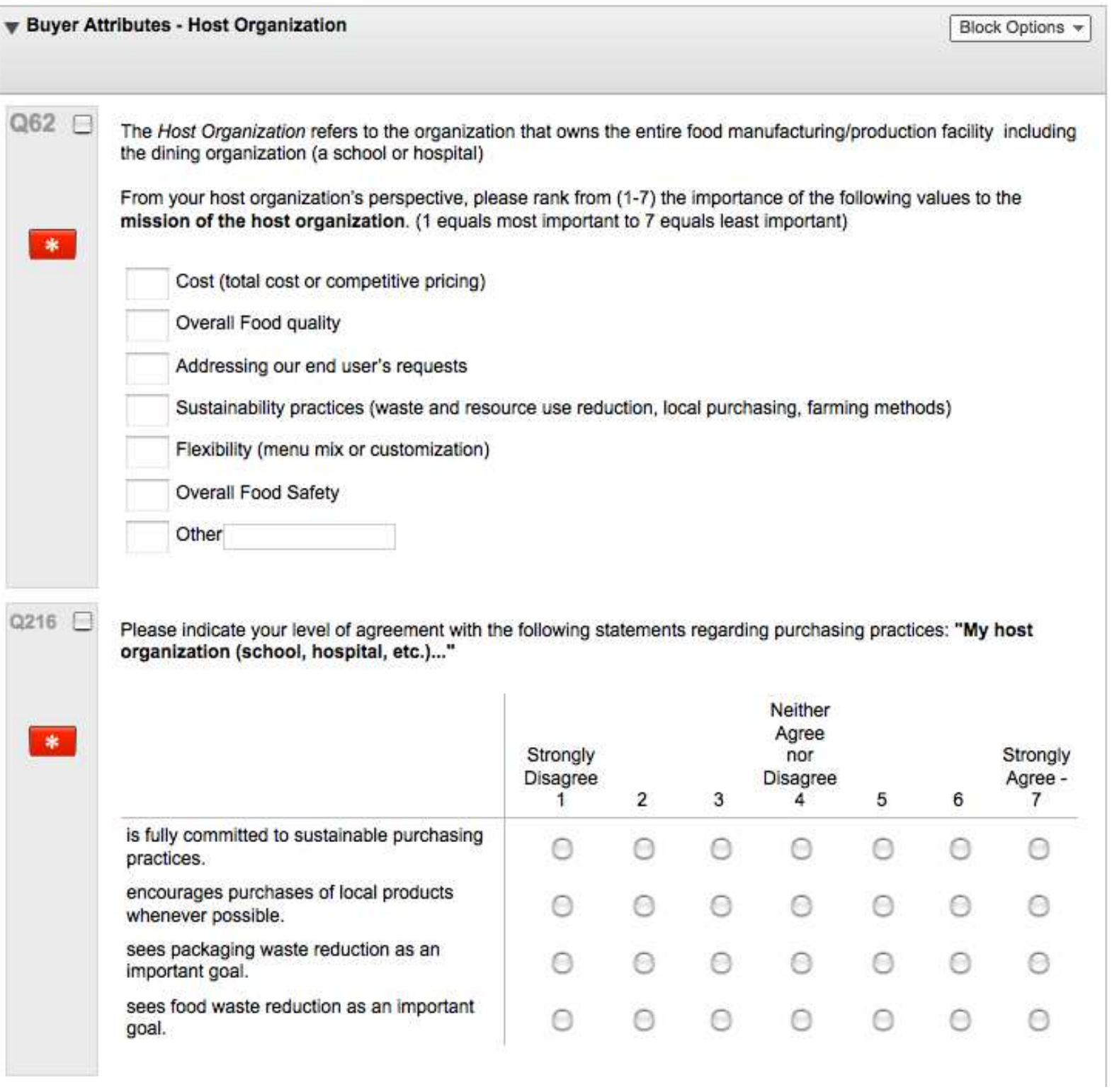




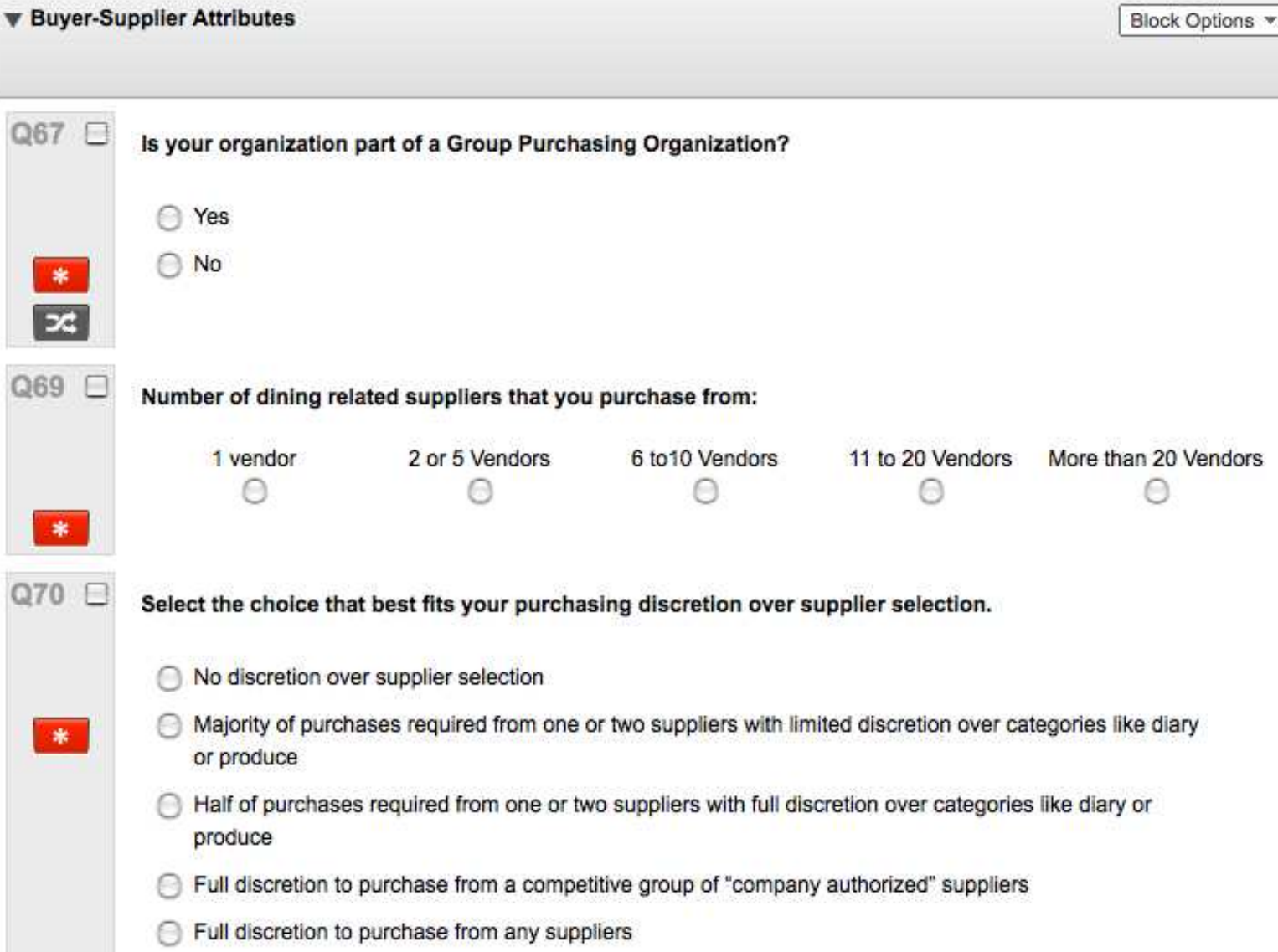

Q67 — Is your organization part of a Group Purchasing Organization?

Yes

* $O$ No

$x$

Q69 $\square$ Number of dining related suppliers that you purchase from:

1 vendor 2 or 5 Vendors 6 to 10 Vendors 11 to 20 Vendors More than 20 Vendors

vendor

$\mathrm{O}$

0

0

Q70 - Select the choice that best fits your purchasing discretion over supplier selection.

No discretion over supplier selection

* $\bigcirc$ Majority of purchases required from one or two suppliers with limited discretion over categories like diary or produce

Half of purchases required from one or two suppliers with full discretion over categories like diary or produce

Full discretion to purchase from a competitive group of "company authorized" suppliers

Full discretion to purchase from any suppliers

\section{Characteristics of food suppliers (\% of purchases)}

Individual farmers

* National food supplier

Local produce distributor

Local dairy supplier

Local meat or seafood supplier

Other

Other 


\begin{tabular}{|c|c|c|c|c|c|c|}
\hline \multirow{2}{*}{$\begin{array}{c}\text { Q217 } \square \\
*\end{array}$} & \multicolumn{6}{|c|}{$\begin{array}{l}\text { Please indicate the extent to which the following issues are obstacles to adopting sustainable food purchasing } \\
\text { practices ( } 1 \text { to } 5 \text { where } 1 \text { is very serious and } 5 \text { is no problem at all) }\end{array}$} \\
\hline & & $\begin{array}{l}\text { Very serious - } \\
1\end{array}$ & 2 & 3 & 4 & $\begin{array}{l}\text { No Problem at } \\
\text { all - } 5\end{array}$ \\
\hline & $\begin{array}{l}\text { Seasonal variation in food } \\
\text { supply }\end{array}$ & 0 & 0 & 0 & 0 & 0 \\
\hline & $\begin{array}{l}\text { Perishability of sustainable } \\
\text { food items }\end{array}$ & 0 & 0 & 0 & 0 & 0 \\
\hline & $\begin{array}{l}\text { Limited breadth of product } \\
\text { line }\end{array}$ & 0 & 0 & 0 & 0 & 0 \\
\hline & $\begin{array}{l}\text { Lack of sustainable } \\
\text { suppliers }\end{array}$ & 0 & 0 & 0 & 0 & 0 \\
\hline & $\begin{array}{l}\text { Lack of competition among } \\
\text { sustainable suppliers }\end{array}$ & 0 & 0 & 0 & 0 & 0 \\
\hline & $\begin{array}{l}\text { Lack of infrastructure for } \\
\text { sustainable suppliers }\end{array}$ & 0 & 0 & 0 & 0 & 0 \\
\hline & $\begin{array}{l}\text { Increased liability for food } \\
\text { safety }\end{array}$ & 0 & 0 & 0 & 0 & 0 \\
\hline & $\begin{array}{l}\text { Lack of trust, safety or } \\
\text { confidence in suppliers of } \\
\text { those products }\end{array}$ & 0 & 0 & 0 & 0 & O \\
\hline & $\begin{array}{l}\text { Lack of supplier information } \\
\text { on farming and processing } \\
\text { characteristics (including } \\
\text { origin) }\end{array}$ & 0 & 0 & 0 & 0 & 0 \\
\hline Q217 $\square$ & \multicolumn{6}{|c|}{$\begin{array}{l}\text { Please indicate the extent to which the following issues are obstacles to reducing food packaging waste } \\
\text { ( } 1 \text { to } 5 \text { where } 1 \text { is very serious and } 5 \text { is no problem at all) }\end{array}$} \\
\hline \multirow{10}{*}{ * } & & $\begin{array}{l}\text { Very serious - } \\
1\end{array}$ & 2 & 3 & 4 & $\begin{array}{l}\text { No Problem at } \\
\text { all - } 5\end{array}$ \\
\hline & $\begin{array}{l}\text { High cost of waste } \\
\text { reduction programs }\end{array}$ & 0 & 0 & 0 & 0 & 0 \\
\hline & $\begin{array}{l}\text { Uneconomic recycling of } \\
\text { packaging }\end{array}$ & 0 & 0 & 0 & 0 & 0 \\
\hline & $\begin{array}{l}\text { Uneconomic reusing of } \\
\text { packaging }\end{array}$ & 0 & 0 & 0 & 0 & 0 \\
\hline & $\begin{array}{l}\text { Lack of management } \\
\text { commitment to waste } \\
\text { reduction }\end{array}$ & 0 & 0 & 0 & 0 & 0 \\
\hline & $\begin{array}{l}\text { Lack of buyer awareness of } \\
\text { waste impacts }\end{array}$ & 0 & 0 & 0 & 0 & 0 \\
\hline & $\begin{array}{l}\text { Lack of supplier awareness } \\
\text { of waste impacts }\end{array}$ & 0 & 0 & 0 & 0 & 0 \\
\hline & $\begin{array}{l}\text { Lack of company-wide } \\
\text { waste reduction standards } \\
\text { or policies }\end{array}$ & 0 & 0 & 0 & 0 & 0 \\
\hline & $\begin{array}{l}\text { Loose city or state waste } \\
\text { management regulations }\end{array}$ & 0 & 0 & 0 & 0 & 0 \\
\hline & $\begin{array}{l}\text { Loose federal waste } \\
\text { management regulations }\end{array}$ & 0 & 0 & 0 & 0 & 0 \\
\hline
\end{tabular}


Product and Processing Characteristics

\begin{tabular}{|l|l|}
\hline Q110 \\
\hline What percentage of your food purchases are from the following categories? \\
\hline R Materials for scratch cooking and baking \\
\hline Pre-processed baking mixes and sauces \\
Pre-chopped or shredded food items \\
Pre-made individual menu items (entrees, salads, etc. \\
Other & 0 \\
\hline Total & 0 \\
\hline
\end{tabular}

Q111 $\square$ Please indicate the level of food preparation facilities that best represents your kitchen area

No food prep or mixing facility

* Kitchen has limited food prep and bakery

Full Kitchen can do simple food prep (chopping, mixing) and baking

Full Kitchen \& simple Bakery (cookies, cakes, etc.)

Full Bakery \& Kitchen

Q219 What percentage of total food purchased is locally grown and processed within 150 miles of your institution?

percentage of total

Q247 $\square$ What percentage of total food purchased is 3rd party certified food or beverage products (Fair Trade, Food Alliance, Organic, Salmon-Safe, Food Alliance, etc.)

percentage of total 


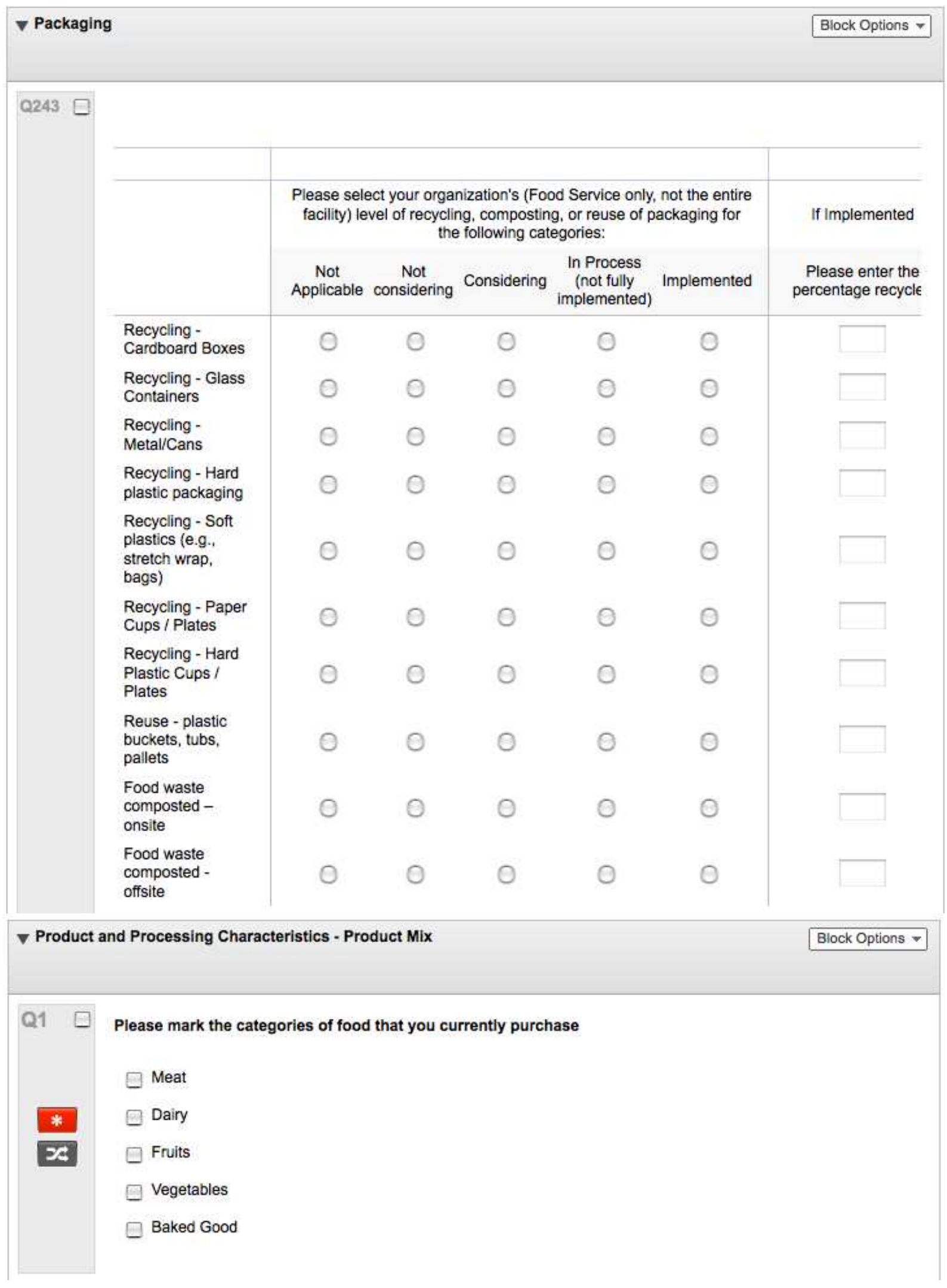




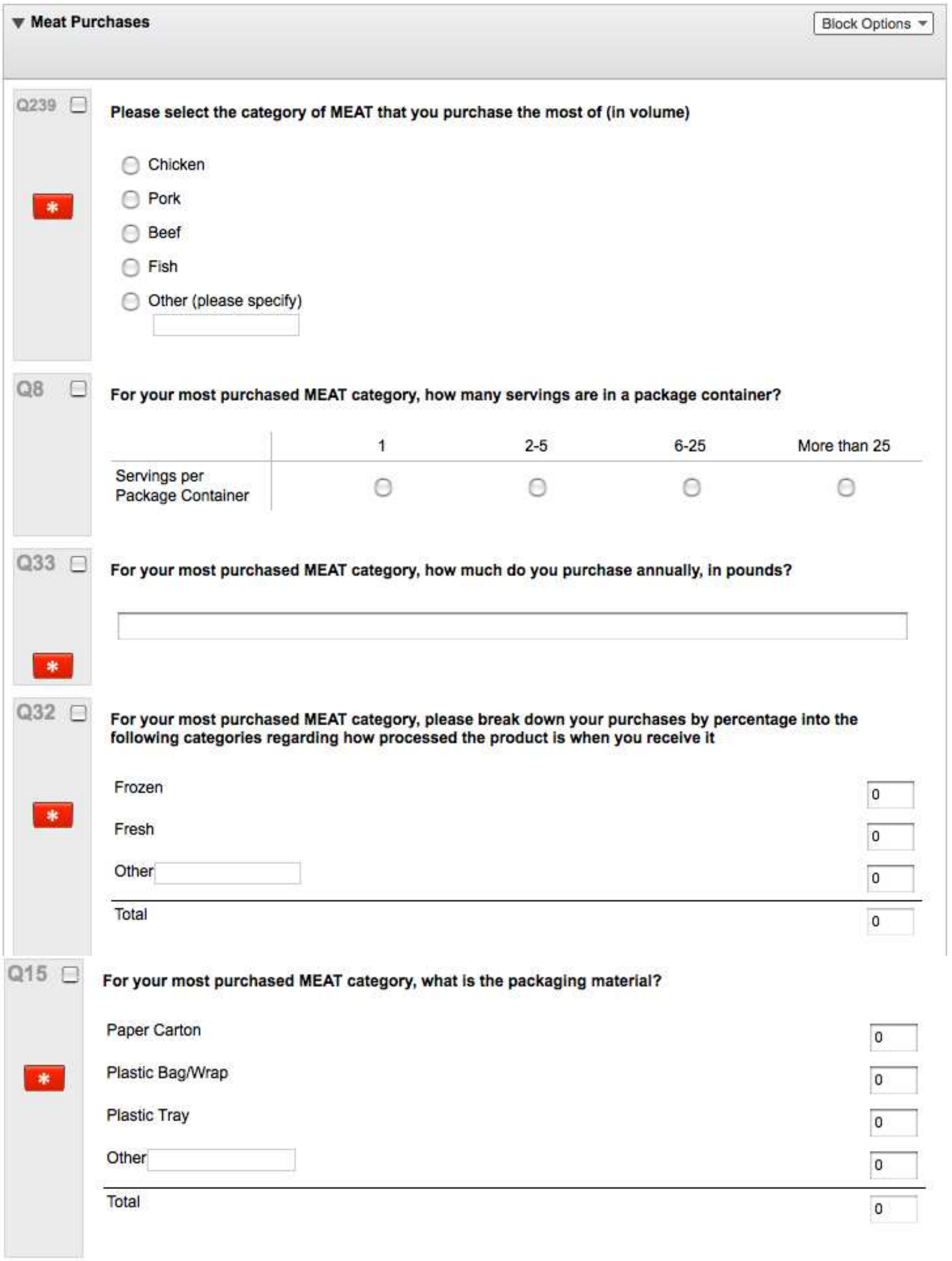




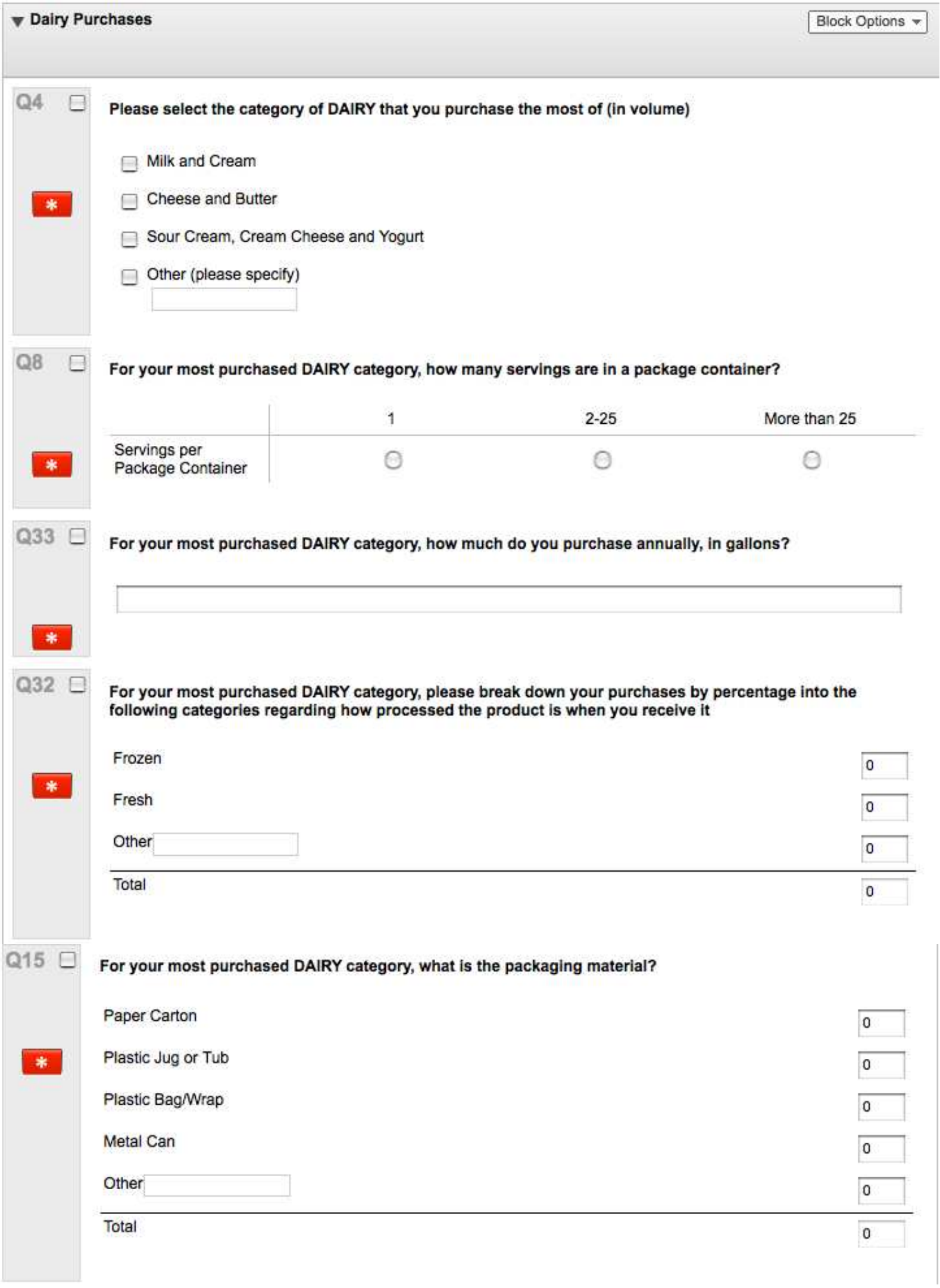




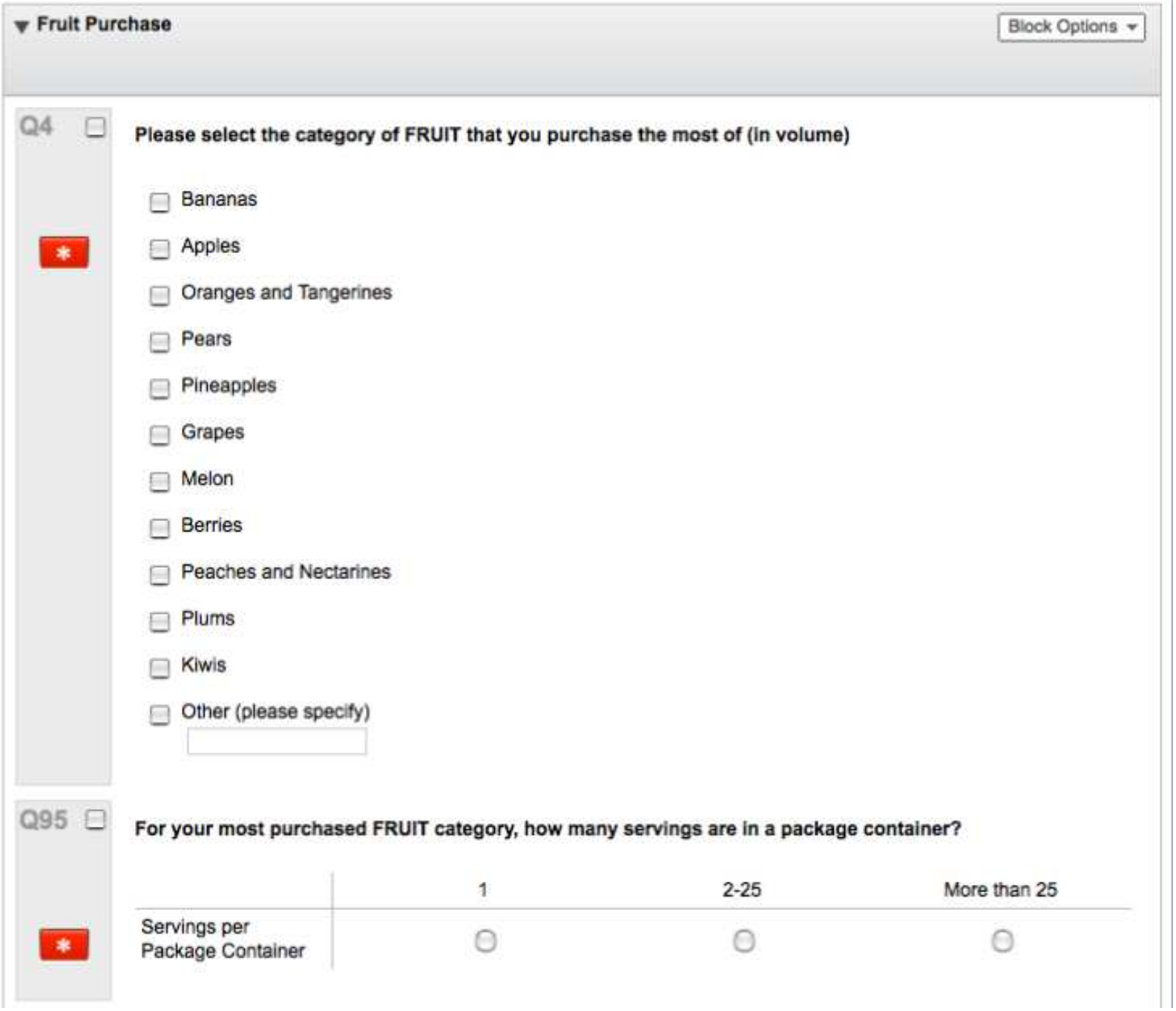




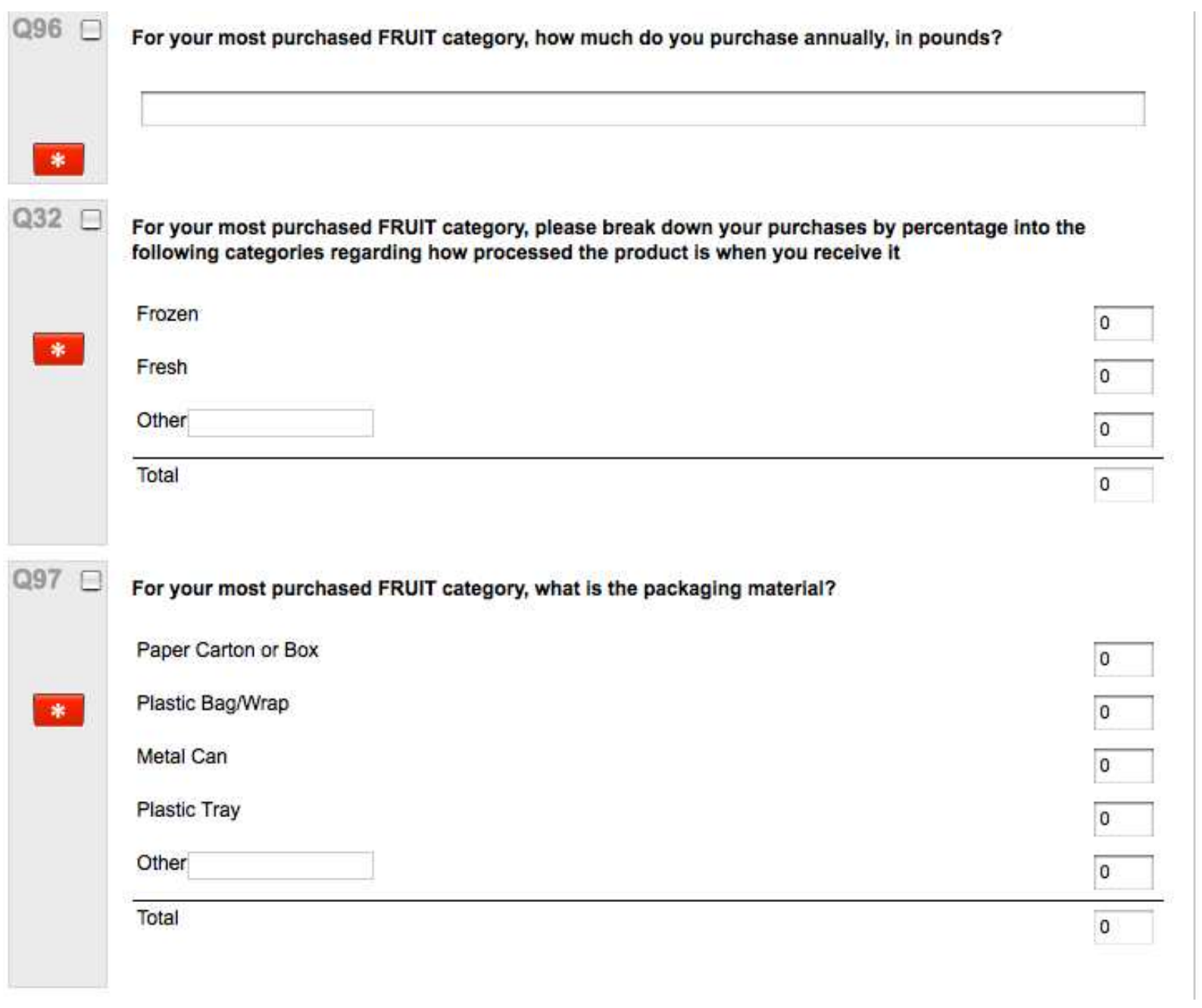




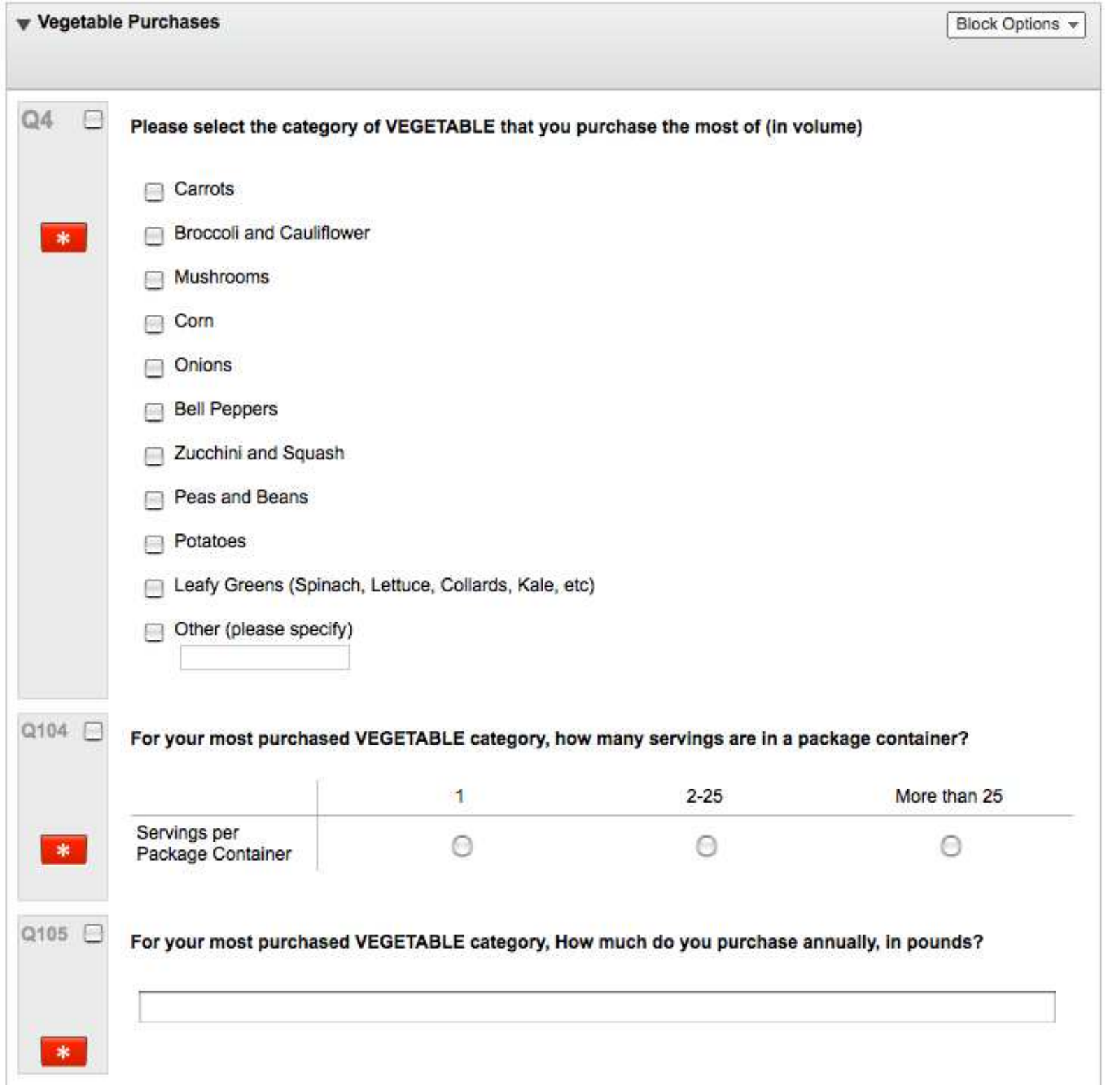




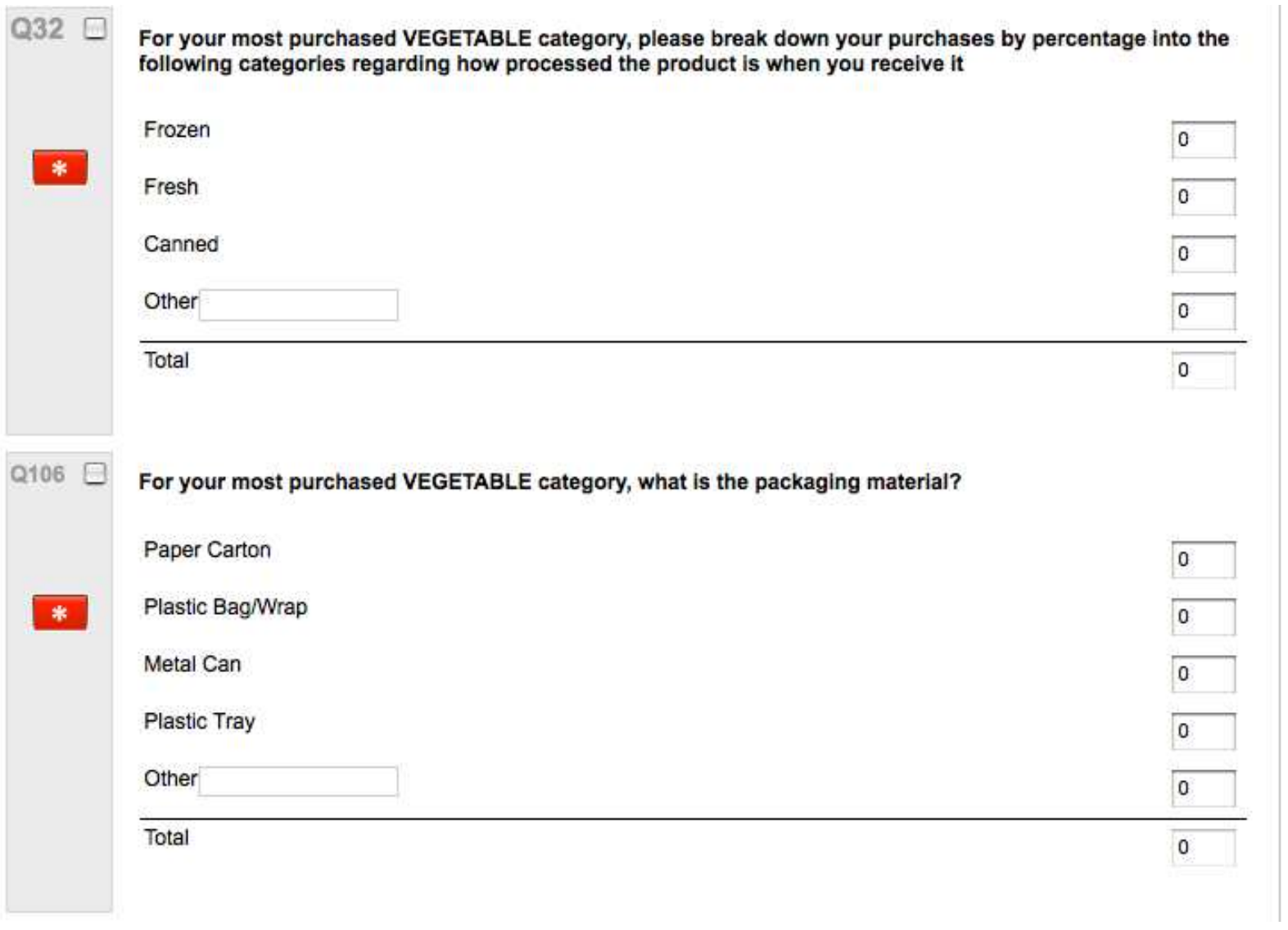




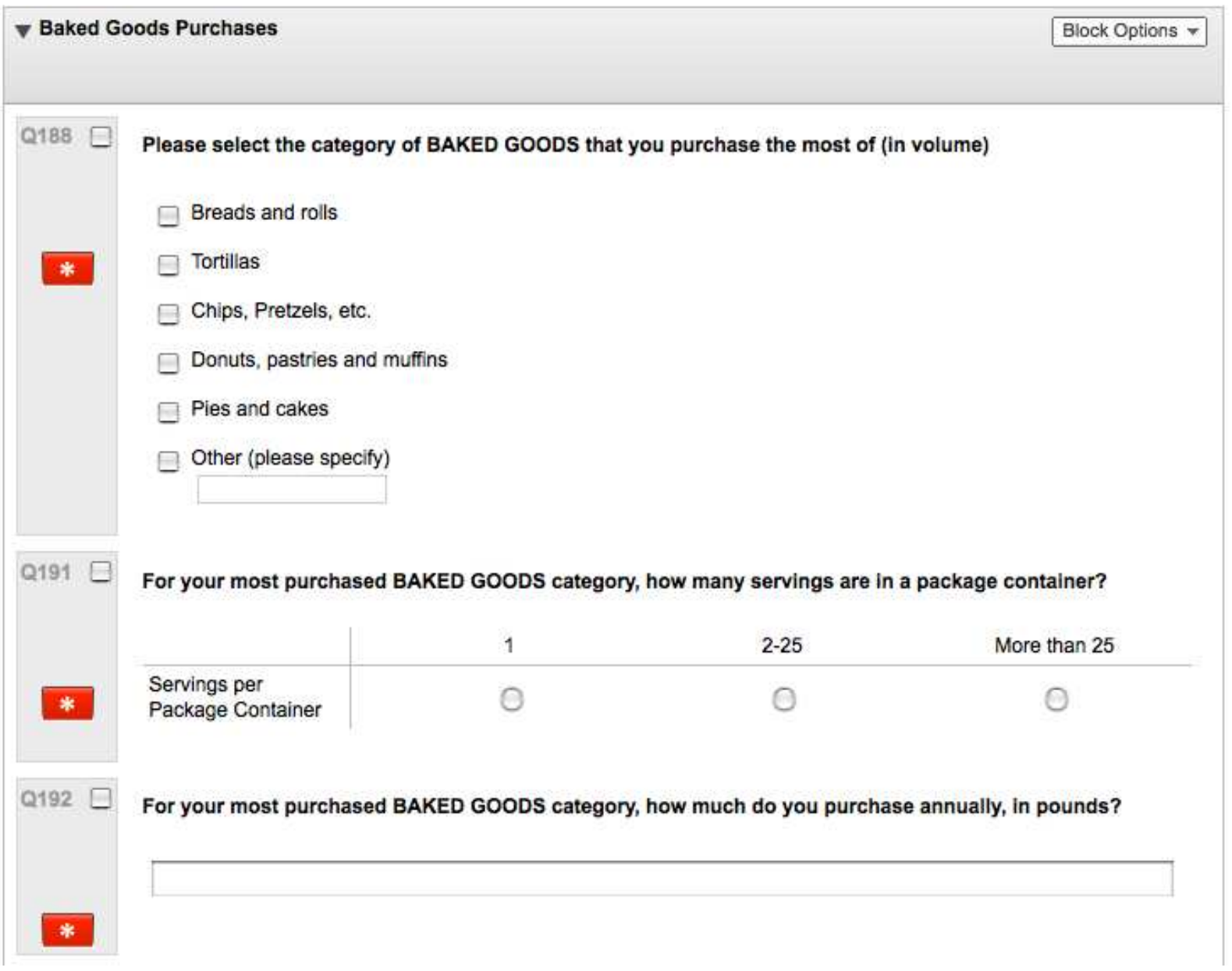




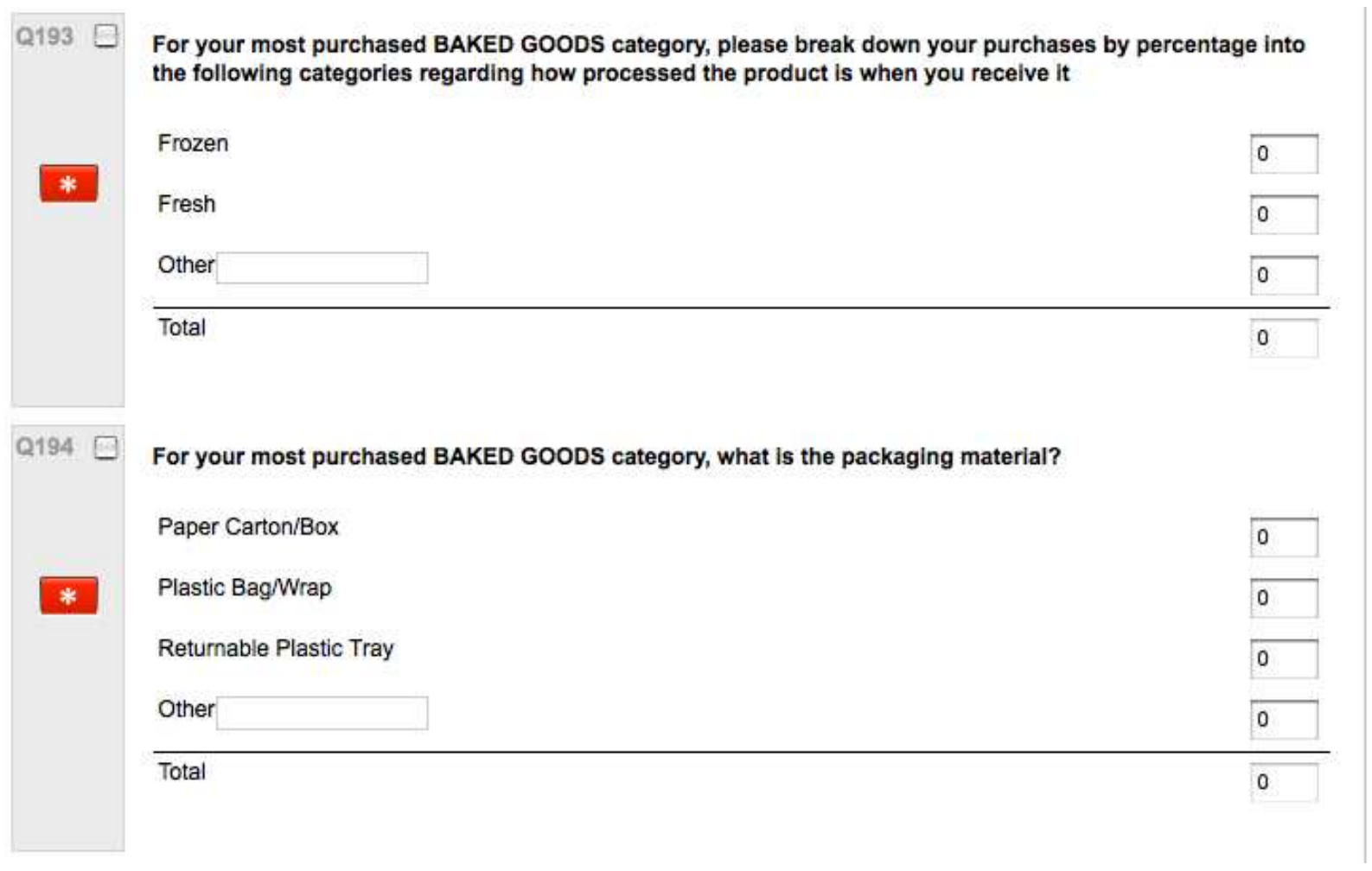




\section{APPENDIX A-3}

\section{FINAL SURVEY INSTRUMENT}

After the pilot survey was conducted, another survey instrument was designed for broader sample size. The pilot survey instrument was similar to the pilot survey, although it excluded many of the specific questions about types of food purchased and packaging for those foods. The survey instrument is summarized in the following paragraphs. The complete survey instrument follows the summary.

- Buyer-Supplier relationship (1 question): Survey respondent is either an employee of the host organization or a contracted buyer.

- Buyer-Customer-Host Organization Alignment: Respondent's priorities in purchasing decisions within their particular purchasing environment (eight or 12 questions total); using a five-point scale of agreement, four statements are given, one about each of: sustainable purchasing, local purchasing, packaging waste reduction, and food waste reduction, and respondents are asked about the priority of each of these statements for

$\circ$ their host organization (four questions)

- their end customer group (four questions)

○ their food purchasing organization (if applicable, four questions).

- Contract Flexibility \& Buyer-supplier relationship (Rábade and Alfaro 2006). Many purchasers have contracts with their supplier that significantly limits the amount and volume of items they can purchase from other suppliers (four questions).

$\circ$ What is the diversity of the respondent's suppliers (five bins)?

- How much discretion does the respondent have regarding suppliers choice (five bins)?

- On five-point scale, measure the extent to which your supplier supports sustainable purchasing and local purchasing (five questions).

- Contract Flexibility \& Buyer-Host Organization relationship (specific to buyer's status as employee or contracted to host organization)

○ On five-point scale, measure the extent to which your host organization supports sustainable purchasing and local purchasing (seven questions).

- Facility Flexibility

○ Level of food preparation facilities (one question)

- Food delivery method (to end customer) of food offered (one question)

- Level of input buyer had in facility construction (one question)

- Assessing packaging and food waste reduction programs for 10 different types of packaging or food waste, and percent reduced if program is implemented (one question).

- Purchasing Practices (five questions)

$\circ$ Level of practice implementation (five-point scale) and percent of category purchased using practice, for the following practices:

- Purchase local from distributor

- Purchase local from source

- Third party

- Bulk food

- Reusable containers 
- Menu Planning Practices (three questions)

- Level of practice implementation (five-point scale) and percent of category purchased using practice, for the following practices:

- seasonal produce

- animal products

- healthy diets

- Characteristics of suppliers for local or sustainable purchasing (one question)

- Demographics (three questions)

- Size of organization

- Type of organization (hospital, private college or university, or public college or university)

- Part of group purchasing organization? 


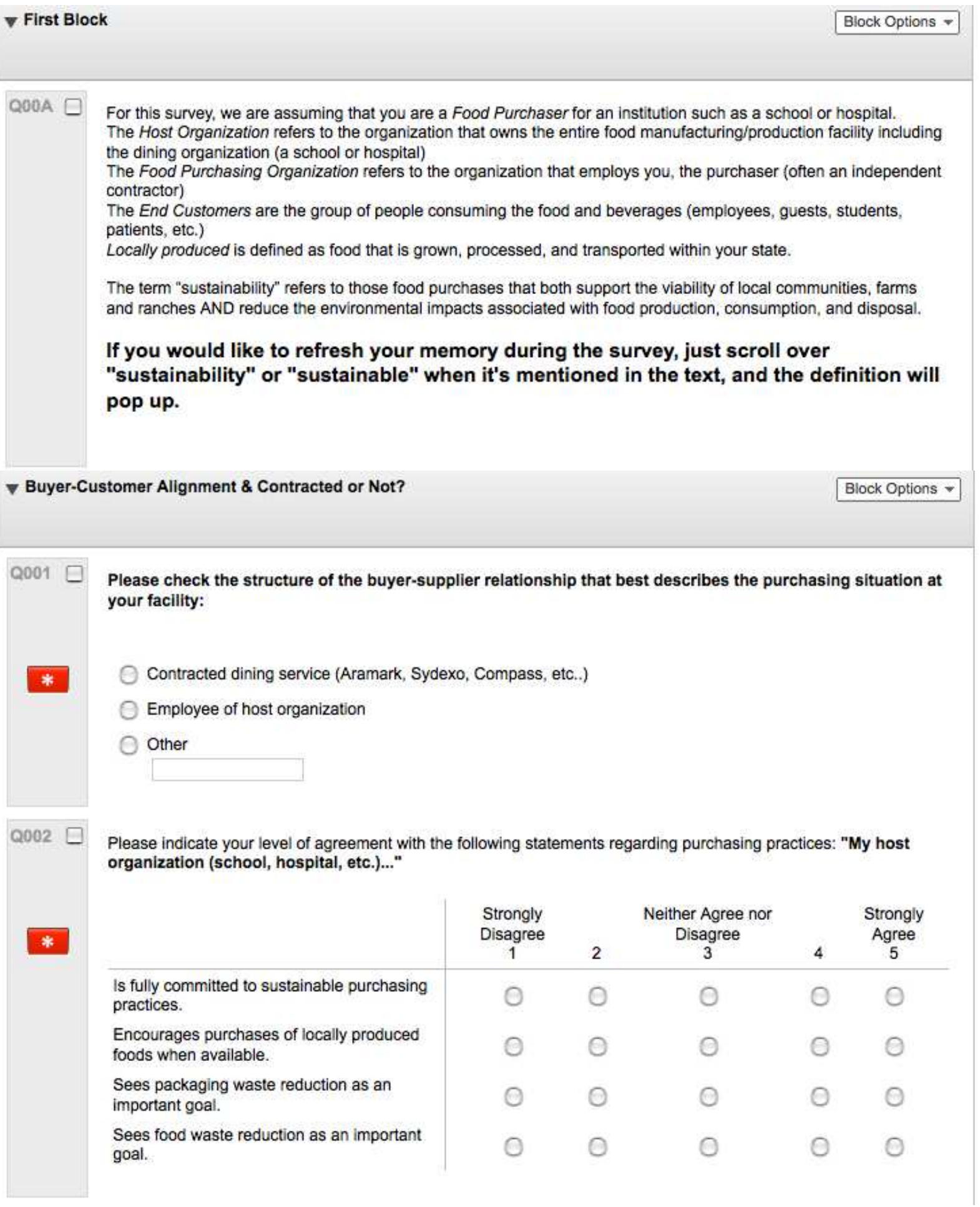




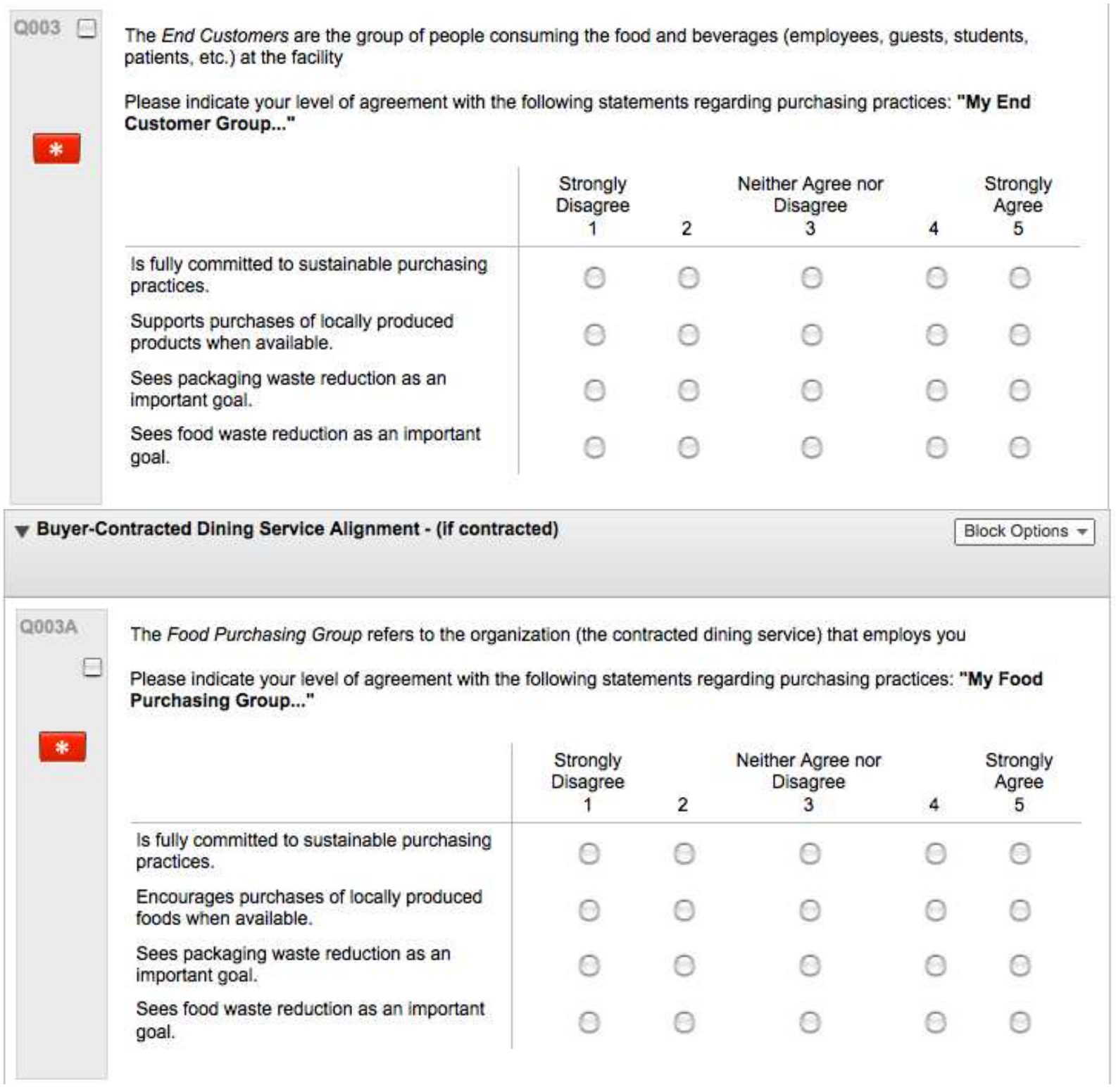




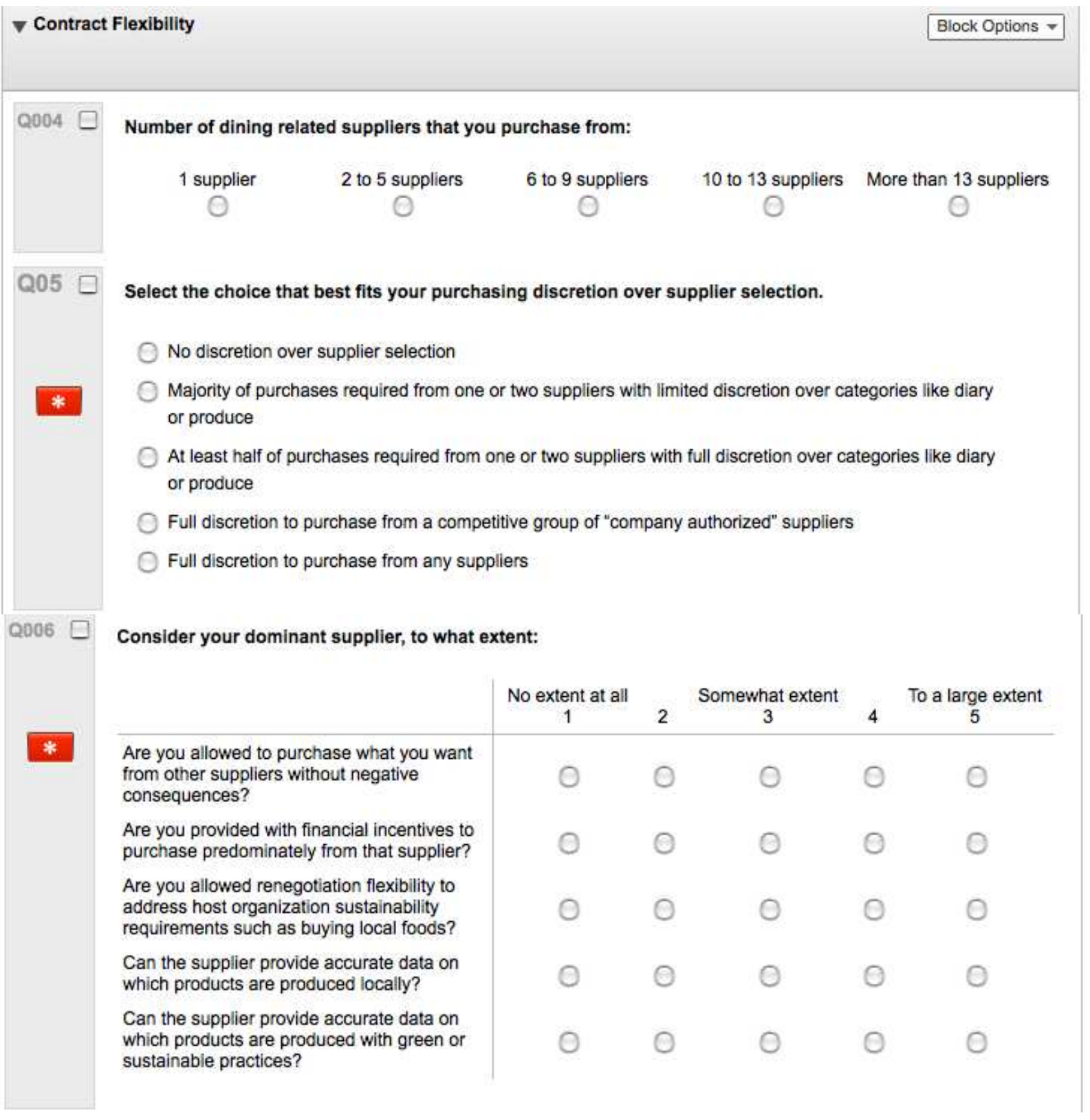




\begin{tabular}{|c|c|c|c|c|c|c|}
\hline \multicolumn{6}{|c|}{$\nabla$ Contract Flexibility - constraint from Host Org - Contracted Employee } & \multirow[t]{2}{*}{ Block Options - } \\
\hline \multirow{9}{*}{ Q006A } & \multicolumn{5}{|c|}{ Considering your contract with your host organization, to what extent are you: } & \\
\hline & & $\begin{array}{c}\text { No extent at all } \\
1\end{array}$ & 2 & $\begin{array}{l}\text { Some Extent } \\
3\end{array}$ & 4 & $\begin{array}{l}\text { To a large extent } \\
5\end{array}$ \\
\hline & $\begin{array}{l}\text { Supported in your efforts to procure } \\
\text { sustainable and local products? }\end{array}$ & O & ○ & 0 & ○ & 0 \\
\hline & $\begin{array}{l}\text { Supported in your efforts to utilize "green" } \\
\text { cleaning products? }\end{array}$ & O & 0 & O & O & O \\
\hline & $\begin{array}{l}\text { Encouraged to promote awareness and } \\
\text { understanding of benefits of local foods, } \\
\text { organics, and "green" products? }\end{array}$ & 0 & O & 0 & O & O \\
\hline & $\begin{array}{l}\text { Encouraged to promote awareness and } \\
\text { understanding of benefits of "green" } \\
\text { systems such as recylcing and } \\
\text { composting? }\end{array}$ & O & 0 & O & O & O \\
\hline & $\begin{array}{l}\text { Encouraged to build partnerships with local } \\
\text { growers and producers? }\end{array}$ & O & O & O & O & O \\
\hline & $\begin{array}{l}\text { Required to provide reports documenting } \\
\text { actual percent of purchased products that } \\
\text { are local, organic, or sustainable? }\end{array}$ & 0 & O & 0 & O & O \\
\hline & $\begin{array}{l}\text { Required to meet established minimums of } \\
\text { local food sourcing and/or organics? }\end{array}$ & O & 0 & O & 0 & O \\
\hline \multicolumn{6}{|c|}{$\nabla$ Contract Flexibility - constraint from Host Org - Host Org Employee } & Block Options - \\
\hline \multirow{9}{*}{ Q006B } & \multicolumn{6}{|c|}{ Considering your organization's purchasing guidelines or contract with you, to what extent are you: } \\
\hline & & $\begin{array}{c}\text { No extent at all } \\
1\end{array}$ & 2 & $\begin{array}{l}\text { Some Extent } \\
3\end{array}$ & 4 & $\begin{array}{l}\text { To a large extent } \\
5\end{array}$ \\
\hline & $\begin{array}{l}\text { Supported in your efforts to procure } \\
\text { sustainable and local products? }\end{array}$ & O & O & O & O & O \\
\hline & $\begin{array}{l}\text { Supported in your efforts to utilize "green" } \\
\text { cleaning products? }\end{array}$ & O & O & O & O & O \\
\hline & $\begin{array}{l}\text { Encouraged to promote awareness and } \\
\text { understanding of benefits of local foods, } \\
\text { organics, and "green" products? }\end{array}$ & O & 0 & O & O & O \\
\hline & $\begin{array}{l}\text { Encouraged to promote awareness and } \\
\text { understanding of benefits of "green" } \\
\text { systems such as recylcing and } \\
\text { composting? }\end{array}$ & 0 & 0 & 0 & 0 & O \\
\hline & $\begin{array}{l}\text { Encouraged to build partnerships with local } \\
\text { growers and producers? }\end{array}$ & O & O & O & O & O \\
\hline & $\begin{array}{l}\text { Required to provide reports documenting } \\
\text { actual percent of purchased products that } \\
\text { are local, organic, or sustainable? }\end{array}$ & O & 0 & 0 & 0 & 0 \\
\hline & $\begin{array}{l}\text { Required to meet established minimums of } \\
\text { local food sourcing and/or organics? }\end{array}$ & 0 & 0 & 0 & 0 & 0 \\
\hline
\end{tabular}


Please indicate the level of food preparation facilities that best represents your food preparation area.

No food prep or mixing facility

* Kitchen has limited food prep and bakery

Full Kitchen can do simple food prep (chopping, mixing) and baking

Full Kitchen \& Simple Bakery (cookies, cakes, etc.)

Full Bakery \& Kitchen

Please indicate food delivery format that best represents the majority of food offered at your institution.

Vending machines of prepackaged food and snacks

Above choices and Grab ' $n$ Go (pre-made food items purchased from external sources)

Above choices and Self Serve (i.e. salad bar)

Above choices and Quick Service (i.e., food items quickly prepared to order)

Above choices with Full service dining (sit down with menu and service)

Q009 $\square \quad$ How much input did your organization have during the design of the current kitchen facilities?

No input at all

Limited input

Some input

Significant input

My organization designed the kitchen 


\begin{tabular}{|c|c|c|c|c|c|c|c|}
\hline \multicolumn{7}{|c|}{ v Packaging Implementation \& Outcomes (Food \& Packaging Waste Reduction) } & Block Options - \\
\hline \multicolumn{8}{|c|}{ Q010 $\square$} \\
\hline \multirow[t]{12}{*}{ * } & & \multicolumn{5}{|c|}{ Level of Formal Practice in place } & \multirow{2}{*}{$\begin{array}{l}\text { Percentage of this } \\
\text { type of waste reduced } \\
\text { (For example: } 50 \% \text { of } \\
\text { available cardboard) } \\
\text { If you can't come up } \\
\text { with an estimate just } \\
\text { enter "NA" }\end{array}$} \\
\hline & & $\begin{array}{c}\text { Not } \\
\text { Considering } \\
1\end{array}$ & $\begin{array}{c}\text { Slightly } \\
\text { Considering } \\
2\end{array}$ & $\begin{array}{c}\text { Informal } \\
\text { Policy } \\
3\end{array}$ & $\begin{array}{c}\text { Formal } \\
\text { Policy } \\
\text { without } \\
\text { goals } \\
4\end{array}$ & $\begin{array}{l}\text { Formal } \\
\text { Policy with } \\
\text { improvement } \\
\text { goals } \\
5\end{array}$ & \\
\hline & $\begin{array}{l}\text { Recycling - } \\
\text { Cardboard Boxes }\end{array}$ & & & & & & \\
\hline & $\begin{array}{l}\text { Recycling - Glass } \\
\text { Containers }\end{array}$ & & & & & & \\
\hline & $\begin{array}{l}\text { Recycling - } \\
\text { Metal/Cans }\end{array}$ & & & & & & \\
\hline & Recycling - Plastic & & & & & & \\
\hline & Recycling - Paper & & & & & & \\
\hline & Reuse - Plastic & & & O & 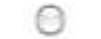 & & \\
\hline & $\begin{array}{l}\text { Compost- Food } \\
\text { waste }\end{array}$ & & & & & & \\
\hline & $\begin{array}{l}\text { Reduce - less } \\
\text { individual servings of } \\
\text { drinks in bottles or } \\
\text { cans }\end{array}$ & & & & & & \\
\hline & $\begin{array}{l}\text { Donate - excess } \\
\text { edible foods to } \\
\text { hunger relief } \\
\text { agencies }\end{array}$ & & & & & & \\
\hline & $\begin{array}{l}\text { Donate - excess } \\
\text { foods for non-human } \\
\text { consumption }\end{array}$ & & & & & & \\
\hline
\end{tabular}




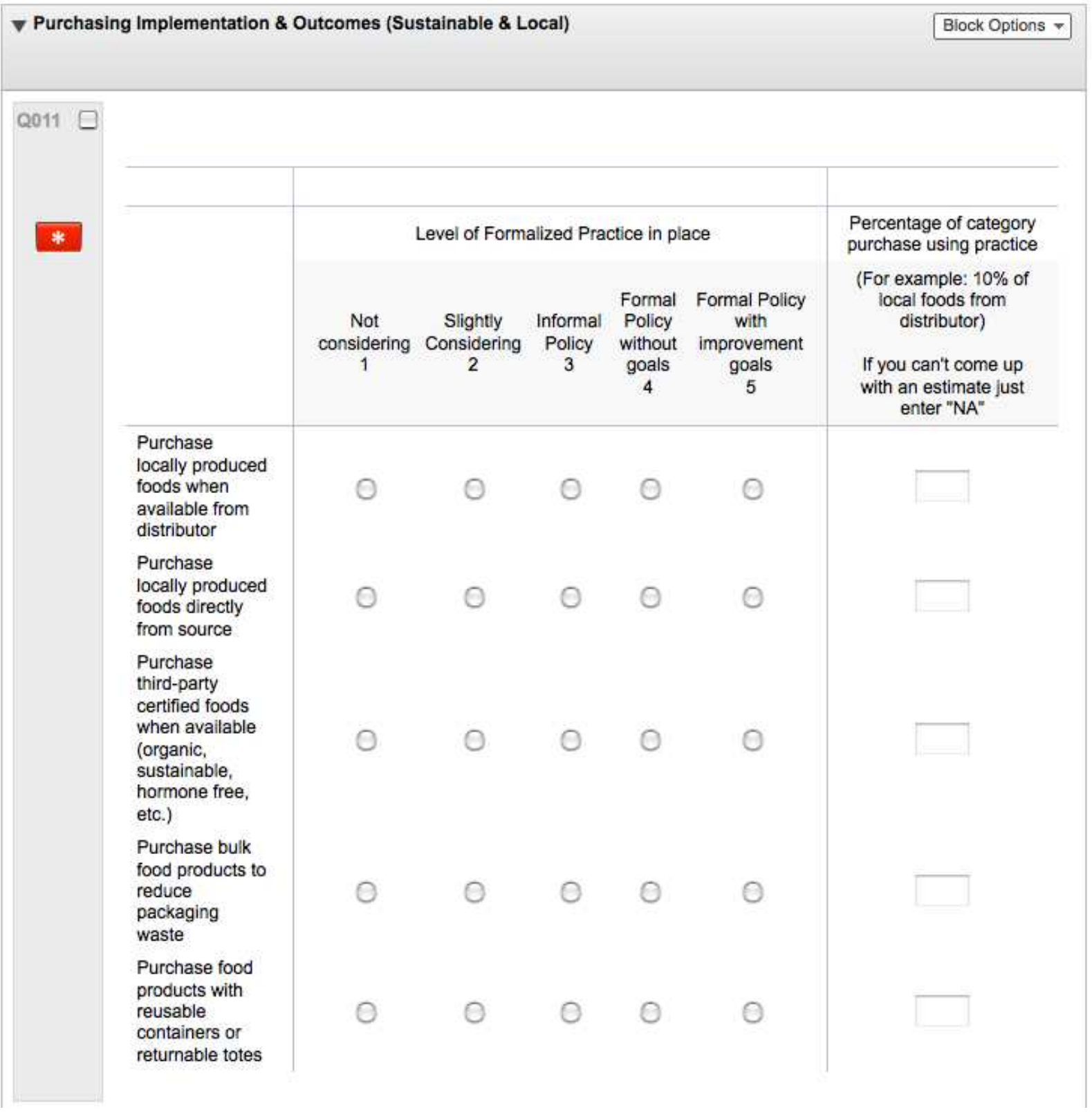




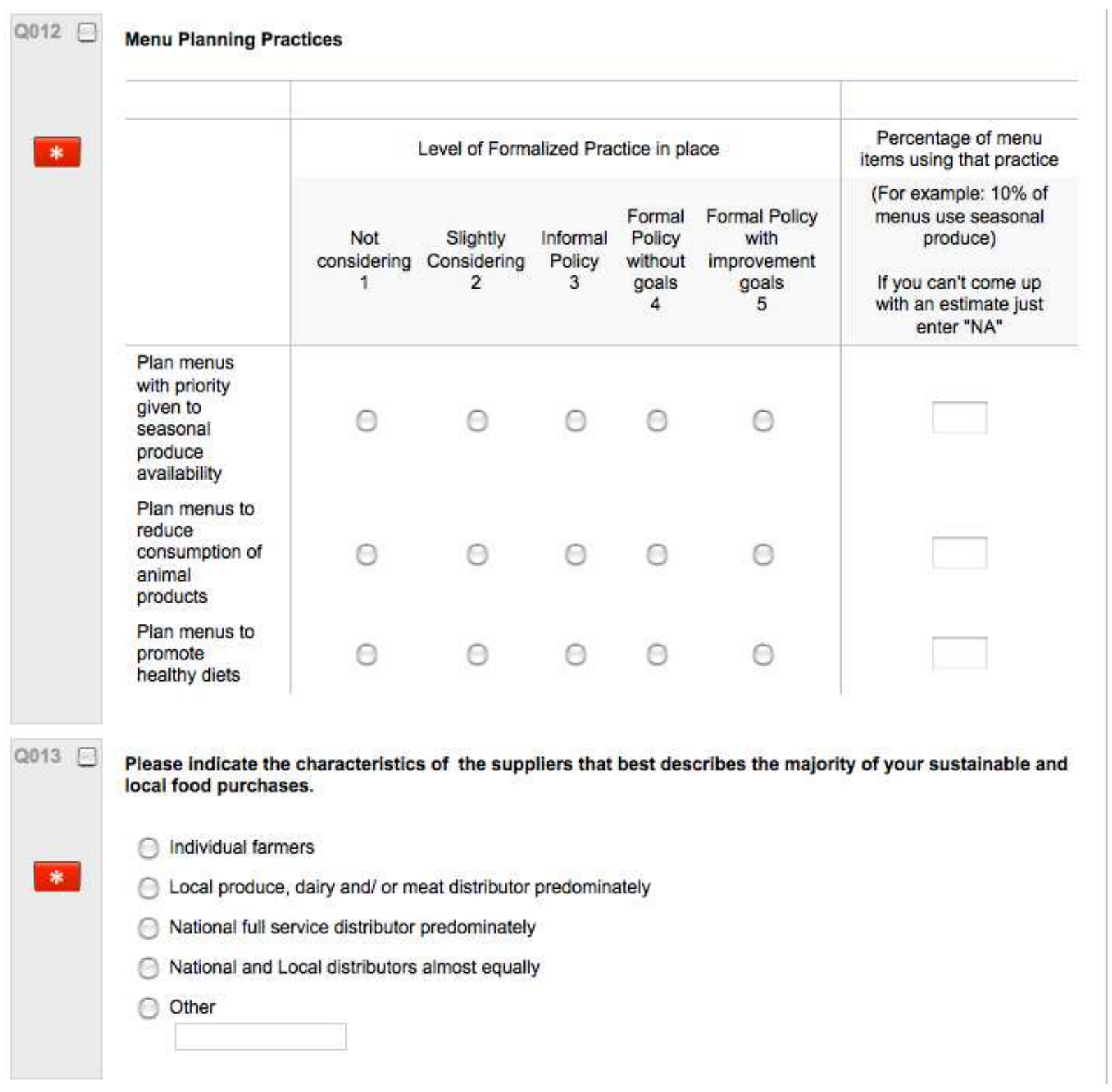




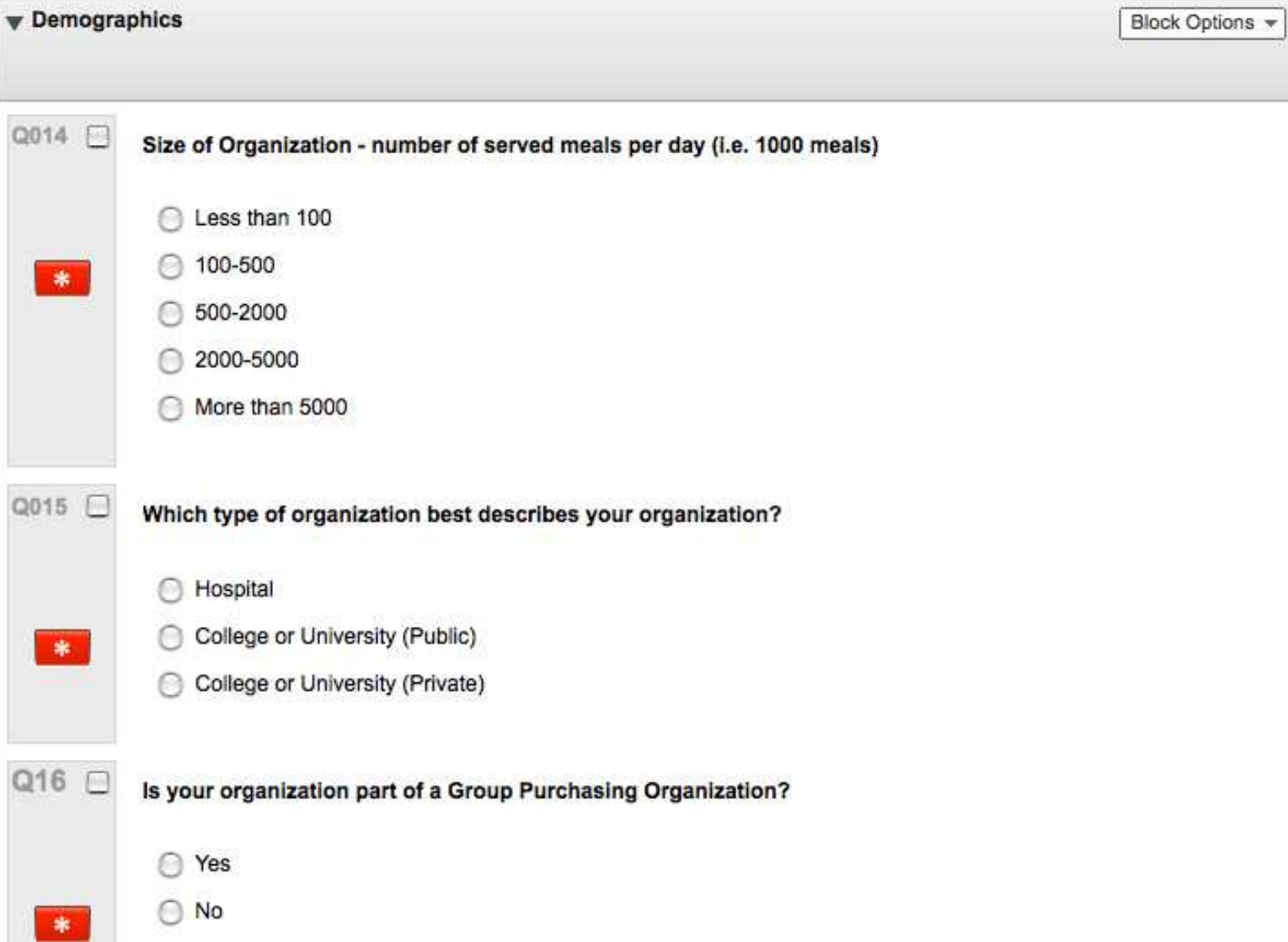




\section{APPENDIX A-4}

\section{DETAILS OF THE METHODS EMPLOYED FOR THE LIFE- CYCLE ANALYSIS}

This Appendix summarizes the methods, standards, data sources, assumptions, and the product systems used in the life-cycle analysis. Some of this same information was provided in the body as well, but is repeated here for clarity.

Note that the term "embodied carbon" means the same as the carbon footprint of a product within a specified system boundary - it is the total greenhouse gas emissions generated by the product life cycle within a system boundary of interest and reported in $\mathrm{Kg}$ of $\mathrm{CO} 2$ equivalents. "Embodied energy" is the total primary energy consumed during the same process and reported in $\mathrm{MJ}$.

\section{- Tools and Data Sources}

- Analytical tool: CarbonScope (http://www.cleanmetrics.com/html/carbonscope.htm)

- Life-cycle inventory (LCI) data for embodied energy and carbon in agricultural production, packaging materials, energy use, transport, etc: CarbonScopeData (http://www.cleanmetrics.com/html/database.htm)

- More details on LCI methodology and specific sources of activity data and emission factors: http://www.cleanmetrics.com/html/lci_methodology.htm

\section{- Standards and Protocols}

- Primary standard used for product life-cycle GHG emissions calculations: PAS 2050 (http://www.bsigroup.com/en/Standards-and-Publications/IndustrySectors/Energy/PAS-2050/)

- PAS 2050 in turn relies on the ISO 14040 series of standards (http://www.iso.org/iso/iso_catalogue/catalogue_tc/catalogue_detail.htm?csnumber=3 7456)

○ 2006 IPCC Guidelines for National Greenhouse Gas Inventories (http://www.ipccnggip.iges.or.jp/public/2006gl/index.html)

\section{- System Boundary for Product Systems}

○ Cradle to grave, including:

- Agricultural production

- Initial processing and packaging

- Transport to institutional kitchen

- Cooking

- Waste disposal

\section{- Functional Units for Analysis}

- It is necessary to choose appropriate functional units for the analysis of each product system. The life-cycle assessment (LCA) is then conducted based on a constant consumption of one functional unit of each product. In this analysis, functional units based on the amount of each product cooked at a time were chosen. Since these functional units are in weight units, it is easy to normalize the final results to per $\mathrm{kg}$ or per serving size of each product as needed. Normalization will be necessary before 
comparing different product systems, but may be less important when comparing different packaging/transport options within the same product system.

- Tomatoes: $3.18 \mathrm{~kg}$

- Potatoes: $9.09 \mathrm{~kg}$

- Chickens: $10.91 \mathrm{~kg}$ (fresh) or $9.09 \mathrm{~kg}$ (frozen)

\section{- Waste and Recycling}

○ For product discarded before or after cooking, the amount consumed (the functional unit) is held constant. The embodied energy and embodied carbon are based on one functional unit of cooked food consumed in each product system, and will increase with increased waste in the product supply chain.

- Composted food waste is assumed to generate negligible amounts of methane. All $\mathrm{CO} 2$ from composting is of biogenic origin and therefore not a contributor to global warming.

- Landfilled plastic packaging materials are assumed to not contain readily degradable organic carbon, and therefore do not contribute to global warming within a 100-year assessment period.

- Landfilled food waste generates significant amounts of methane, which are included in the product's life-cycle embodied carbon.

- Landfill methane emissions are modeled based on IPCC guidelines, with a weighted average computed over a 100-year assessment period per the PAS 2050 standard, under the following conditions: Temperate/wet climate zone, no oxidation of methane in the soil or covering, assume $50 \%$ of landfill gas is methane, and $25 \%$ of methane is recovered and combusted as fuel.

- All recycling is handled on an open-loop basis. Recycled materials used in packaging may originate from the same product system (closed-loop), or more likely from different product systems (open-loop). Appropriate credit is given (by way of lower embodied energy and carbon) for the recycled content of materials used in packaging.

- No credit is given for used packaging materials that are recycled after use in order to avoid double counting the benefits of recycling.

\section{- Cooking Equipment}

- Blodgett Full-size Dual Flow Gas Convection Oven (DFG-100) - includes two oven sections (http://www.vittitow.com/auction_html/used/blodgett/DFG100-spec.pdf).

- Wolf Challenger XL 36" Gas Restaurant Range (C36B-6) - includes six burners (http://www.wolfrange.com/specs/restaurant_ranges/F-37362(7-08).pdf).

- Marsal \& Sons steam table (MS 8 PAN) - includes eight pan slots (http://www.marsalsons.com/steamtables.html).

- Assuming that all cooking occurs within Oregon. Where electricity is used, emission factors based on the power grid area covering Oregon were used.

\section{- Transport Distances}

○ Farm to kitchen - long: 1,000 km (tomatoes, potatoes) or 1,600 km (chicken), using a semi-trailer truck.

- With frozen storage for chicken.

○ Farm to kitchen - short: $160 \mathrm{~km}$ for all products, using a single-unit truck.

- With refrigerated storage for chicken.

- Kitchen to waste disposal (compost/landfill/recycle): $100 \mathrm{~km}$, using a single-unit truck or equivalent. 


\section{- Agricultural Production}

- California agricultural data for tomatoes and potatoes exists, and the same data for local production in Oregon was used.

- Only data for chicken production in Denmark exists, so it was used as a substitute for U.S. production. The data is for "chicken meat" only and not for whole chicken.

\section{- Tomato Product System}

- Functional unit: $3.18 \mathrm{~kg}$ of diced raw tomatoes consumed as part of a cooked pasta casserole.

- Production location: California and Oregon.

- Package option \#1:

- One steel can (29\% recycled) per $3.18 \mathrm{~kg}$ of tomatoes

- Can: $0.303 \mathrm{~kg}$

- Six cans per corrugated cardboard box

○ Package option \#2:

- Box: $0.355 \mathrm{~kg}$

- One polyethylene bag with cap (closest approximation to PE clear-barrier EVOH) per $3.18 \mathrm{~kg}$ of tomatoes

- Bag: $0.061 \mathrm{~kg}$

- Eight bags per corrugated cardboard box

- Box: $0.355 \mathrm{~kg}$

○ Cooking: $3.18 \mathrm{~kg}$ of diced tomatoes (from one can or bag) used in a pasta casserole

- $10 \%$ of tomato mass lost via draining/evaporation

- Casserole cooked at 350 degrees for one hour in an oven, using half of one oven compartment.

- Placed on steam table for one hour, using 1/8 of the steam table.

○ Waste:

- Cooking calculations apply to the whole casserole.

- Polyethylene bags are landfilled.

- Steel cans and cardboard box are recycled.

- Food waste options:

- No waste.

- $50 \%$ discarded before cooking and composted.

- $50 \%$ discarded after cooking and landfilled.

- Waste calculations apply only to the tomato portion of the casserole and not the whole casserole.

\section{- Potato Product System}

○ Functional unit: 50 cooked potatoes consumed, using $9.09 \mathrm{~kg}$ of raw potatoes.

- Production location: California and Oregon.

- Package option \#1:

- 100 potatoes in a corrugated cardboard box

- Box: $0.355 \mathrm{~kg}$

- Package option \#2:

- 100 potatoes in a reusable polypropylene tote

- Tote: $2.05 \mathrm{~kg}$

○ Cooking:

- $10 \%$ of potato mass lost as peeling waste and composted. 
- 25 potatoes cooked in oven for one hour, using half of one oven compartment.

- 25 potatoes cooked on range (stove top) for 30 minutes, using two burners.

○ Waste:

- Placed on steam table for two hours, using $2 / 8$ of the steam table.

- Polypropylene tote is recycled after 100 uses.

- Cardboard box is recycled.

- Food waste options:

- No waste.

- $50 \%$ discarded before cooking and composted.

- $50 \%$ discarded after cooking and landfilled.

\section{- Chicken Product System}

○ Fresh Chicken

- Functional unit: $10.91 \mathrm{~kg}$ of chicken consumed (equivalent to half a box).

- Production location: Oregon.

- Package:

- 12 whole chickens $(21.82 \mathrm{~kg}$ ) packaged using:

○ Polyethylene bags: $0.425 \mathrm{~kg}(15 \mathrm{oz})$

○ Cardboard box: $0.441 \mathrm{~kg}$

- Farm to kitchen transport: $160 \mathrm{~km}$ (local)

○ Frozen Chicken

- Functional unit: $9.09 \mathrm{~kg}$ of chicken consumed (equivalent to half a box).

- Production location: U.S.

- Package:

- $18.18 \mathrm{~kg}$ of chicken pieces packaged using:

○ Polyethylene bags: $0.34 \mathrm{~kg}(12 \mathrm{oz})$

○ Cardboard box: $0.441 \mathrm{~kg}$

- Farm to kitchen transport: 1,600 km (from some middle part of the U.S. to Oregon)

○ Cooking:

- Half box of fresh/frozen chicken cooked in oven for one hour, using one full oven compartment.

- Placed on steam table for four hours, using $2 / 8$ of the steam table.

○ Waste:

- Polyethylene bags are landfilled.

- Cardboard box is recycled.

- Food waste options:

- No waste.

- $50 \%$ discarded before cooking and landfilled.

- $50 \%$ discarded after cooking and landfilled.

Some data for the tables below are not from Oregon. When reliable Oregon data was not available, reliable data was taken from elsewhere. More specifically, the chicken production data is from Denmark because no other reliable chicken production data is available at this time. For tomatoes and potatoes, data from California is used. For each of the three product systems, the production data is for one specific location, and the same production data is used for all production locations. This is, of course, an approximation since production energy use and 
emissions for the same product can vary somewhat between locations, but it is a reasonable approximation and helps to put the rest of the analysis in context in terms of relative impacts of different life-cycle stages and components. 
Tomatoes-LongDist-SteelCan-NoWaste

\begin{tabular}{|l|l|l|l|l|} 
NodeOrLink & Type & Mode & $\begin{array}{l}\text { Embodied } \\
\text { Energy }\end{array}$ & $\begin{array}{l}\text { Embodied } \\
\text { Carbon }\end{array}$ \\
\hline Packing <TO> Cooking & Transport & Transport, semi-trailer truck & 3.51 & 0.267 \\
\hline Cooking <TO> Waste Disposal & Transport & Transport, single-unit truck & 0.09 & 0.007 \\
\hline Raw Production & Process & Tomatoes, California, USA & 7.56 & 0.685 \\
\hline Corrugated Cardboard & Process & Cardboard, corrugated, 38\% recycled & 1.76 & 0.073 \\
\hline Steel Can & Process & Steel, virgin; Steel, recycled & 8.45 & 0.631 \\
\hline Packing & Process & Electricity, at grid, California & 9.06 & 0.556 \\
\hline & & $\begin{array}{l}\text { Natural gas, combusted in industrial } \\
\text { equipment; Electricity, at grid, } \\
\text { Washington, Oregon, Nevada, Idaho, } \\
\text { western Montana, Wyoming, Utah }\end{array}$ & 44.19 & 2.909 \\
\hline Cooking & & & 74.61 & 5.128
\end{tabular}

Tomatoes-LongDist-SteelCanCompostBfCooking

\begin{tabular}{|c|c|c|c|c|}
\hline NodeOrLink & Type & Mode & $\begin{array}{l}\text { Embodied } \\
\text { Energy }\end{array}$ & $\begin{array}{l}\text { Embodied } \\
\text { Carbon }\end{array}$ \\
\hline Packing <TO > Cooking & Transport & Transport, semi-trailer truck & 7.01 & 0.534 \\
\hline Cooking <TO> Waste Disposal & Transport & Transport, single-unit truck & 0.93 & 0.071 \\
\hline Raw Production & Process & Tomatoes, California, USA & 15.12 & 1.371 \\
\hline Corrugated Cardboard & Process & Cardboard, corrugated, $38 \%$ recycled & 3.53 & 0.146 \\
\hline Steel Can & Process & Steel, virgin; Steel, recycled & 16.89 & 1.261 \\
\hline Packing & Process & Electricity, at grid, California & 18.13 & 1.112 \\
\hline Cooking & Process & $\begin{array}{l}\text { Natural gas, combusted in industrial } \\
\text { equipment; Electricity, at grid, } \\
\text { Washington, Oregon, Nevada, Idaho, } \\
\text { western Montana, Wyoming, Utah }\end{array}$ & 44.19 & 2.909 \\
\hline TOTAL & & & 105.8 & 7.405 \\
\hline
\end{tabular}

Tomatoes-LongDist-SteelCan-LandfillAfCooking

\begin{tabular}{|l|l|l|l|l|} 
NodeOrLink & Type & Mode & $\begin{array}{l}\text { Embodied } \\
\text { Energy }\end{array}$ & $\begin{array}{l}\text { Embodied } \\
\text { Carbon }\end{array}$ \\
\hline Packing <TO> Cooking & Transport & Transport, semi-trailer truck & 7.01 & 0.534 \\
\hline Cooking <TO> Waste Disposal & Transport & Transport, single-unit truck & 0.93 & 0.071 \\
\hline Raw Production & Process & Tomatoes, California, USA & 15.12 & 1.371 \\
\hline Corrugated Cardboard & Process & Cardboard, corrugated, 38\% recycled & 3.53 & 0.146 \\
\hline Steel Can & Process & Steel, virgin; Steel, recycled & 16.89 & 1.261 \\
\hline Packing & Process & Electricity, at grid, California & 18.13 & 1.112 \\
\hline & & $\begin{array}{l}\text { Natural gas, combusted in industrial } \\
\text { equipment; Electricity, at grid, } \\
\text { Washington, Oregon, Nevada, Idaho, }\end{array}$ & & \\
\hline Cooking & & western Montana, Wyoming, Utah & 88.37 & 5.819 \\
\hline Waste Disposal & Process & 0 & 3.027 \\
\hline TOTAL & Process & FoodWaste:Landfill & 149.99 & 13.341
\end{tabular}


Tomatoes-LongDist-PeBag-NoWaste

\begin{tabular}{|l|l|l|r|r|}
\multicolumn{1}{|c|}{ NodeOrLink } & \multicolumn{1}{|c|}{ Type } & \multicolumn{1}{c|}{ Mode } & $\begin{array}{c}\text { Embodied } \\
\text { Energy }\end{array}$ & $\begin{array}{c}\text { Embodied } \\
\text { Carbon }\end{array}$ \\
\hline Packing <TO> Cooking & Transport & Transport, semi-trailer truck & 3.33 & 0.254 \\
\hline Cooking <TO> Waste Disposal & Transport & Transport, single-unit truck & 0.04 & 0.003 \\
\hline Raw Production & Process & Tomatoes, California, USA & 7.54 & 0.684 \\
\hline Corrugated Cardboard & Process & Cardboard, corrugated, 38\% recycled & 1.32 & 0.055 \\
\hline PE Bag & Process & Polyethylene, general & 5.54 & 0.129 \\
\hline Packing & Process & Electricity, at grid, California & 9.05 & 0.555 \\
\hline & & $\begin{array}{l}\text { Natural gas, combusted in industrial } \\
\text { equipment; Electricity, at grid, }\end{array}$ & & \\
Cooking & & Washington, Oregon, Nevada, Idaho, & & \\
\hline TOTAL & Process & western Montana, Wyoming, Utah & 44.19 & 2.909 \\
\hline
\end{tabular}

Tomatoes-LongDist-PeBagCompostBfCooking

\begin{tabular}{|c|c|c|c|c|}
\hline NodeOrLink & Type & Mode & $\begin{array}{l}\text { Embodie } \\
\text { d Energy } \\
\end{array}$ & $\begin{array}{c}\text { Embodied } \\
\text { Carbon } \\
\end{array}$ \\
\hline Packing <TO > Cooking & Transport & Transport, semi-trailer truck & 6.66 & 0.507 \\
\hline Cooking <TO> Waste Disposal & Transport & Transport, single-unit truck & 0.84 & 0.064 \\
\hline Raw Production & Process & Tomatoes, California, USA & 15.09 & 1.368 \\
\hline Corrugated Cardboard & Process & Cardboard, corrugated, $38 \%$ recycled & 2.64 & 0.109 \\
\hline PE Bag & Process & Polyethylene, general & 11.07 & 0.259 \\
\hline Packing & Process & Electricity, at grid, California & 18.09 & 1.11 \\
\hline Cooking & Process & $\begin{array}{l}\text { Natural gas, combusted in industrial } \\
\text { equipment; Electricity, at grid, } \\
\text { Washington, Oregon, Nevada, Idaho, } \\
\text { western Montana, Wyoming, Utah }\end{array}$ & 44.19 & 2.909 \\
\hline TOTAL & & & 98.58 & 6.327 \\
\hline
\end{tabular}

Tomatoes-LongDist-PeBag-LandfillAfCooking

\begin{tabular}{|l|l|l|r|r|}
\multicolumn{1}{|c|}{ NodeOrLink } & \multicolumn{1}{|c|}{ Type } & \multicolumn{1}{c|}{ Mode } & $\begin{array}{c}\text { Embodie } \\
\text { d Energy }\end{array}$ & $\begin{array}{c}\text { Embodied } \\
\text { Carbon }\end{array}$ \\
\hline Packing <TO> Cooking & Transport & Transport, semi-trailer truck & 6.66 & 0.507 \\
\hline Cooking <TO> Waste Disposal & Transport & Transport, single-unit truck & 0.84 & 0.064 \\
\hline Raw Production & Process & Tomatoes, California, USA & 15.09 & 1.368 \\
\hline Corrugated Cardboard & Process & Cardboard, corrugated, 38\% recycled & 2.64 & 0.109 \\
\hline PE Bag & Process & Polyethylene, general & 11.07 & 0.259 \\
\hline Packing & Process & Electricity, at grid, California & 18.09 & 1.11 \\
\hline & & $\begin{array}{l}\text { Natural gas, combusted in industrial } \\
\text { equipment; Electricity, at grid, }\end{array}$ & & \\
Cooking & & Washington, Oregon, Nevada, Idaho, & 88.37 & 5.819 \\
\hline Waste Disposal & Process & western Montana, Wyoming, Utah & 0 & 3.027 \\
\hline TOTAL & Process & FoodWaste:Landfill & 142.77 & 12.263 \\
\hline
\end{tabular}


Tomatoes-ShortDist-SteelCan-NoWaste

\begin{tabular}{|c|c|c|c|c|}
\hline NodeOrLink & Type & Mode & $\begin{array}{l}\text { Embodied } \\
\text { Energy }\end{array}$ & $\begin{array}{l}\text { Embodied } \\
\text { Carbon }\end{array}$ \\
\hline Packing <TO> Cooking & Transport & Transport, single-unit truck & 1.35 & 0.103 \\
\hline Cooking <TO> Waste Disposal & Transport & Transport, single-unit truck & 0.09 & 0.007 \\
\hline Raw Production & Process & Tomatoes, California, USA & 7.56 & 0.685 \\
\hline Corrugated Cardboard & Process & Cardboard, corrugated, $38 \%$ recycled & 1.76 & 0.073 \\
\hline Steel Can & Process & Steel, virgin; Steel, recycled & 8.45 & 0.631 \\
\hline Packing & Process & $\begin{array}{l}\text { Electricity, at grid, Washington, } \\
\text { Oregon, Nevada, Idaho, western } \\
\text { Montana, Wyoming, Utah }\end{array}$ & 7.38 & 0.554 \\
\hline Cooking & Process & $\begin{array}{l}\text { Natural gas, combusted in industrial } \\
\text { equipment; Electricity, at grid, } \\
\text { Washington, Oregon, Nevada, Idaho, } \\
\text { western Montana, Wyoming, Utah }\end{array}$ & 44.19 & 2.909 \\
\hline TOTAL & & & 70.78 & 4.962 \\
\hline
\end{tabular}

TomatoesShortDistSteelCanCompostBfCooking

\begin{tabular}{|c|c|c|c|c|}
\hline NodeOrLink & Type & Mode & $\begin{array}{l}\text { Embodied } \\
\text { Energy }\end{array}$ & $\begin{array}{l}\text { Embodied } \\
\text { Carbon }\end{array}$ \\
\hline Packing <TO > Cooking & Transport & Transport, single-unit truck & 2.71 & 0.206 \\
\hline Cooking <TO> Waste Disposal & Transport & Transport, single-unit truck & 0.93 & 0.071 \\
\hline Raw Production & Process & Tomatoes, California, USA & 15.12 & 1.371 \\
\hline Corrugated Cardboard & Process & Cardboard, corrugated, $38 \%$ recycled & 3.53 & 0.146 \\
\hline Steel Can & Process & Steel, virgin; Steel, recycled & 16.89 & 1.261 \\
\hline Packing & Process & $\begin{array}{l}\text { Electricity, at grid, Washington, } \\
\text { Oregon, Nevada, Idaho, western } \\
\text { Montana, Wyoming, Utah }\end{array}$ & 14.77 & 1.108 \\
\hline Cooking & Process & $\begin{array}{l}\text { Natural gas, combusted in industrial } \\
\text { equipment; Electricity, at grid, } \\
\text { Washington, Oregon, Nevada, Idaho, } \\
\text { western Montana, Wyoming, Utah }\end{array}$ & 44.19 & 2.909 \\
\hline TOTAL & & & 98.13 & 7.072 \\
\hline
\end{tabular}


Tomatoes ShortDistSteelCanLandfillAfCooking

\begin{tabular}{|l|l|l|r|r|}
\multicolumn{1}{|c|}{ NodeOrLink } & \multicolumn{1}{|c|}{ Type } & \multicolumn{1}{c|}{ Mode } & $\begin{array}{c}\text { Embodied } \\
\text { Energy }\end{array}$ & $\begin{array}{c}\text { Embodied } \\
\text { Carbon }\end{array}$ \\
\hline Packing <TO> Cooking & Transport & Transport, single-unit truck & 2.71 & 0.206 \\
\hline Cooking <TO> Waste Disposal & Transport & Transport, single-unit truck & 0.93 & 0.071 \\
\hline Raw Production & Process & Tomatoes, California, USA & 15.12 & 1.371 \\
\hline Corrugated Cardboard & Process & Cardboard, corrugated, 38\% recycled & 3.53 & 0.146 \\
\hline Steel Can & Process & Steel, virgin; Steel, recycled & 16.89 & 1.261 \\
\hline & & $\begin{array}{l}\text { Electricity, at grid, Washington, } \\
\text { Oregon, Nevada, Idaho, western }\end{array}$ & & 14.77 \\
Packing & Process & Montana, Wyoming, Utah & 1.108 \\
\hline & & $\begin{array}{l}\text { Natural gas, combusted in industrial } \\
\text { equipment; Electricity, at grid, }\end{array}$ & & \\
Cooking & Washington, Oregon, Nevada, Idaho, & 88.37 & 5.819 \\
\hline Waste Disposal & Process & western Montana, Wyoming, Utah & & \\
\hline TOTAL & Process & FoodWaste:Landfill & 142.32 & 13.009
\end{tabular}

Tomatoes-ShortDist-PeBag-NoWaste

\begin{tabular}{|c|c|c|c|c|}
\hline NodeOrLink & Type & Mode & $\begin{array}{l}\text { Embodied } \\
\text { Energy }\end{array}$ & $\begin{array}{c}\text { Embodied } \\
\text { Carbon }\end{array}$ \\
\hline Packing $<\mathrm{TO}>$ Cooking & Transport & Transport, single-unit truck & 1.29 & 0.098 \\
\hline Cooking <TO> Waste Disposal & Transport & Transport, single-unit truck & 0.04 & 0.003 \\
\hline Raw Production & Process & Tomatoes, California, USA & 7.54 & 0.684 \\
\hline Corrugated Cardboard & Process & Cardboard, corrugated, $38 \%$ recycled & 1.32 & 0.055 \\
\hline PE Bag & Process & Polyethylene, general & 5.54 & 0.129 \\
\hline Packing & Process & $\begin{array}{l}\text { Electricity, at grid, Washington, } \\
\text { Oregon, Nevada, Idaho, western } \\
\text { Montana, Wyoming, Utah }\end{array}$ & 7.37 & 0.553 \\
\hline Cooking & Process & $\begin{array}{l}\text { Natural gas, combusted in industrial } \\
\text { equipment; Electricity, at grid, } \\
\text { Washington, Oregon, Nevada, Idaho, } \\
\text { western Montana, Wyoming, Utah }\end{array}$ & 44.19 & 2.909 \\
\hline TOTAL & & & 67.28 & 4.431 \\
\hline
\end{tabular}


Tomatoes-ShortDist-PeBagCompostBfCooking

\begin{tabular}{|c|c|c|c|c|}
\hline NodeOrLink & Type & Mode & $\begin{array}{l}\text { Embodied } \\
\text { Energy }\end{array}$ & $\begin{array}{l}\text { Embodied } \\
\text { Carbon }\end{array}$ \\
\hline Packing <TO> Cooking & Transport & Transport, single-unit truck & 2.57 & 0.196 \\
\hline Cooking <TO> Waste Disposal & Transport & Transport, single-unit truck & 0.84 & 0.064 \\
\hline Raw Production & Process & Tomatoes, California, USA & 15.09 & 1.368 \\
\hline Corrugated Cardboard & Process & Cardboard, corrugated, $38 \%$ recycled & 2.64 & 0.109 \\
\hline PE Bag & Process & Polyethylene, general & 11.07 & 0.259 \\
\hline Packing & Process & $\begin{array}{l}\text { Electricity, at grid, Washington, } \\
\text { Oregon, Nevada, Idaho, western } \\
\text { Montana, Wyoming, Utah }\end{array}$ & 14.74 & 1.105 \\
\hline Cooking & Process & $\begin{array}{l}\text { Natural gas, combusted in industrial } \\
\text { equipment; Electricity, at grid, } \\
\text { Washington, Oregon, Nevada, Idaho, } \\
\text { western Montana, Wyoming, Utah }\end{array}$ & 44.19 & 2.909 \\
\hline TOTAL & & & 91.14 & 6.011 \\
\hline
\end{tabular}

Tomatoes-ShortDist-PeBag-LandfillAfCooking

\begin{tabular}{|c|c|c|c|c|}
\hline NodeOrLink & Type & Mode & $\begin{array}{l}\text { Embodied } \\
\text { Energy }\end{array}$ & $\begin{array}{l}\text { Embodied } \\
\text { Carbon }\end{array}$ \\
\hline Packing <TO> Cooking & Transport & Transport, single-unit truck & 2.57 & 0.196 \\
\hline Cooking <TO> Waste Disposal & Transport & Transport, single-unit truck & 0.84 & 0.064 \\
\hline Raw Production & Process & Tomatoes, California, USA & 15.09 & 1.368 \\
\hline Corrugated Cardboard & Process & Cardboard, corrugated, $38 \%$ recycled & 2.64 & 0.109 \\
\hline PE Bag & Process & Polyethylene, general & 11.07 & 0.259 \\
\hline Packing & Process & $\begin{array}{l}\text { Electricity, at grid, Washington, } \\
\text { Oregon, Nevada, Idaho, western } \\
\text { Montana, Wyoming, Utah }\end{array}$ & 14.74 & 1.105 \\
\hline Cooking & Process & $\begin{array}{l}\text { Natural gas, combusted in industrial } \\
\text { equipment; Electricity, at grid, } \\
\text { Washington, Oregon, Nevada, Idaho, } \\
\text { western Montana, Wyoming, Utah }\end{array}$ & 88.37 & 5.819 \\
\hline Waste Disposal & Process & FoodWaste:Landfill & 0 & 3.027 \\
\hline TOTAL & & & 135.33 & 11.947 \\
\hline
\end{tabular}


Potatoes-LongDist-Cardboard-NoWaste

\begin{tabular}{|l|l|l|l|l|} 
NodeOrLink & Type & Mode & $\begin{array}{l}\text { Embodied } \\
\text { Energy }\end{array}$ & $\begin{array}{l}\text { Embodied } \\
\text { Carbon }\end{array}$ \\
\hline Packing <TO> Cooking & Transport & Transport, semi-trailer truck & 9.15 & 0.697 \\
\hline Cooking <TO> Waste Disposal & Transport & Transport, single-unit truck & 0.04 & 0.003 \\
\hline Raw Production & Process & Potatoes, California, USA & 89.94 & 6.66 \\
\hline Corrugated Cardboard & Process & Cardboard, corrugated, 38\% recycled & 5.28 & 0.219 \\
\hline Packing & Process & & 0 & 0 \\
\hline & & $\begin{array}{l}\text { Natural gas, combusted in industrial } \\
\text { equipment; Electricity, at grid, } \\
\text { Washington, Oregon, Nevada, Idaho, } \\
\text { western Montana, Wyoming, Utah }\end{array}$ & 112.91 & 7.623 \\
\hline Cooking & & & 217.33 & 15.202 \\
\hline TOTAL & Process & & & \\
\hline
\end{tabular}

Potatoes-LongDist-Cardboard-CompostBfCooking

\begin{tabular}{|l|l|l|l|l|} 
NodeOrLink & Type & Mode & $\begin{array}{l}\text { Embodied } \\
\text { Energy }\end{array}$ & $\begin{array}{l}\text { Embodied } \\
\text { Carbon }\end{array}$ \\
\hline Packing <TO> Cooking & Transport & Transport, semi-trailer truck & 18.31 & 1.394 \\
\hline Cooking <TO> Waste Disposal & Transport & Transport, single-unit truck & 2.03 & 0.155 \\
\hline Raw Production & Process & Potatoes, California, USA & 179.87 & 13.32 \\
\hline Corrugated Cardboard & Process & $\begin{array}{l}\text { Cardboard, corrugated, 38\% } \\
\text { recycled }\end{array}$ & 10.57 & 0.438 \\
\hline Packing & Process & & 0 & 0 \\
\hline & & $\begin{array}{l}\text { Natural gas, combusted in } \\
\text { industrial equipment; Electricity, } \\
\text { at grid, Washington, Oregon, } \\
\text { Nevada, Idaho, western Montana, } \\
\text { Wyoming, Utah }\end{array}$ & & 112.91 \\
\hline Cooking & & & 323.7 & 7.623 \\
\hline TOTAL & Process & & & 22.929 \\
\hline
\end{tabular}

Potatoes-LongDist-Cardboard-LandfillAfCooking

\begin{tabular}{|c|c|c|c|c|}
\hline NodeOrLink & Type & Mode & $\begin{array}{l}\text { Embodied } \\
\text { Energy }\end{array}$ & $\begin{array}{l}\text { Embodied } \\
\text { Carbon }\end{array}$ \\
\hline Packing <TO > Cooking & Transport & Transport, semi-trailer truck & 18.31 & 1.394 \\
\hline Cooking <TO > Waste Disposal & Transport & Transport, single-unit truck & 2.04 & 0.155 \\
\hline Raw Production & Process & Potatoes, California, USA & 179.87 & 13.32 \\
\hline Corrugated Cardboard & Process & $\begin{array}{l}\text { Cardboard, corrugated, } 38 \% \\
\text { recycled }\end{array}$ & 10.57 & 0.438 \\
\hline Packing & Process & & 0 & 0 \\
\hline Cooking & Process & $\begin{array}{l}\text { Natural gas, combusted in } \\
\text { industrial equipment; Electricity, } \\
\text { at grid, Washington, Oregon, } \\
\text { Nevada, Idaho, western Montana, } \\
\text { Wyoming, Utah }\end{array}$ & 225.83 & 15.245 \\
\hline Waste Disposal & Process & FoodWaste:Landfill & 0 & 8.658 \\
\hline TOTAL & & & 436.61 & 39.21 \\
\hline
\end{tabular}


Potatoes-LongDist-Plastic-NoWaste

\begin{tabular}{|l|l|l|l|l|} 
NodeOrLink & Type & Mode & $\begin{array}{l}\text { Embodied } \\
\text { Energy }\end{array}$ & $\begin{array}{l}\text { Embodied } \\
\text { Carbon }\end{array}$ \\
\hline Packing <TO> Cooking & Transport & Transport, semi-trailer truck & 9.99 & 0.761 \\
\hline Cooking <TO> Waste Disposal & Transport & Transport, single-unit truck & 0.24 & 0.019 \\
\hline Raw Production & Process & Potatoes, California, USA & 89.94 & 6.66 \\
\hline Polypropylene & Process & $\begin{array}{l}\text { Polypropylene, injection } \\
\text { moulding }\end{array}$ & 1.18 & 0.04 \\
\hline Packing & Process & & 0 & 0 \\
\hline & & $\begin{array}{l}\text { Natural gas, combusted in } \\
\text { industrial equipment; Electricity, } \\
\text { at grid, Washington, Oregon, } \\
\text { Nevada, Idaho, western Montana, } \\
\text { Wyoming, Utah }\end{array}$ & & \\
Cooking & & & 214.26 & 12.91 \\
\hline TOTAL & Process & & 7.623 \\
\hline
\end{tabular}

Potatoes-LongDist-Plastic-CompostBfCooking

\begin{tabular}{|l|l|l|l|l|} 
NodeOrLink & Type & Mode & $\begin{array}{l}\text { Embodied } \\
\text { Energy }\end{array}$ & $\begin{array}{l}\text { Embodied } \\
\text { Carbon }\end{array}$ \\
\hline Packing <TO> Cooking & Transport & Transport, semi-trailer truck & 19.98 & 1.522 \\
\hline Cooking <TO> Waste Disposal & Transport & Transport, single-unit truck & 2.44 & 0.186 \\
\hline Raw Production & Process & Potatoes, California, USA & 179.87 & 13.32 \\
\hline Polypropylene & Process & $\begin{array}{l}\text { Polypropylene, injection } \\
\text { moulding }\end{array}$ & 2.36 & 0.08 \\
\hline Packing & Process & & 0 & 0 \\
\hline & & $\begin{array}{l}\text { Natural gas, combusted in } \\
\text { industrial equipment; Electricity, } \\
\text { at grid, Washington, Oregon, } \\
\text { Nevada, Idaho, western Montana, } \\
\text { Wyoming, Utah }\end{array}$ & & 112.91 \\
Cooking & & & 317.57 & 22.73 \\
\hline TOTAL & Process & & & 7.623 \\
\hline
\end{tabular}

Potatoes-LongDist-Plastic-LandfillAfCooking

\begin{tabular}{|c|c|c|c|c|}
\hline NodeOrLink & Type & Mode & $\begin{array}{l}\text { Embodied } \\
\text { Energy }\end{array}$ & $\begin{array}{l}\text { Embodied } \\
\text { Carbon }\end{array}$ \\
\hline Packing <TO > Cooking & Transport & Transport, semi-trailer truck & 19.98 & 1.522 \\
\hline Cooking <TO > Waste Disposal & Transport & Transport, single-unit truck & 2.44 & 0.186 \\
\hline Raw Production & Process & Potatoes, California, USA & 179.87 & 13.32 \\
\hline Polypropylene & Process & $\begin{array}{l}\text { Polypropylene, injection } \\
\text { moulding }\end{array}$ & 2.36 & 0.08 \\
\hline Packing & Process & & 0 & 0 \\
\hline Cooking & Process & $\begin{array}{l}\text { Natural gas, combusted in } \\
\text { industrial equipment; Electricity, } \\
\text { at grid, Washington, Oregon, } \\
\text { Nevada, Idaho, western Montana, } \\
\text { Wyoming, Utah }\end{array}$ & 225.83 & 15.245 \\
\hline Waste Disposal & Process & FoodWaste:Landfill & 0 & 8.658 \\
\hline TOTAL & & & 430.48 & 39.01 \\
\hline
\end{tabular}

Potatoes-ShortDist-Cardboard-NoWaste 


\begin{tabular}{|l|l|l|l|l|} 
NodeOrLink & Type & Mode & $\begin{array}{l}\text { Embodied } \\
\text { Energy }\end{array}$ & $\begin{array}{l}\text { Embodied } \\
\text { Carbon }\end{array}$ \\
\hline Packing <TO> Cooking & Transport & Transport, semi-trailer truck & 1.46 & 0.112 \\
\hline Cooking <TO> Waste Disposal & Transport & Transport, single-unit truck & 0.04 & 0.003 \\
\hline Raw Production & Process & Potatoes, California, USA & 89.94 & 6.66 \\
\hline Corrugated Cardboard & Process & $\begin{array}{l}\text { Cardboard, corrugated, 38\% } \\
\text { recycled }\end{array}$ & 5.28 & 0.219 \\
\hline Packing & Process & & 0 & 0 \\
\hline & & $\begin{array}{l}\text { Natural gas, combusted in } \\
\text { industrial equipment; Electricity, } \\
\text { at grid, Washington, Oregon, } \\
\text { Nevada, Idaho, western Montana, } \\
\text { Wyoming, Utah }\end{array}$ & & \\
Cooking & & & 209.64 & 112.91 \\
\hline TOTAL & Process & & 7.623 \\
\hline
\end{tabular}

Potatoes-ShortDist-Cardboard-CompostBfCooking

\begin{tabular}{|l|l|l|l|l|} 
NodeOrLink & Type & Mode & $\begin{array}{l}\text { Embodied } \\
\text { Energy }\end{array}$ & $\begin{array}{l}\text { Embodied } \\
\text { Carbon }\end{array}$ \\
\hline Packing <TO> Cooking & Transport & Transport, semi-trailer truck & 2.93 & 0.223 \\
\hline Cooking <TO> Waste Disposal & Transport & Transport, single-unit truck & 2.03 & 0.155 \\
\hline Raw Production & Process & Potatoes, California, USA & 179.87 & 13.32 \\
\hline Corrugated Cardboard & Process & $\begin{array}{l}\text { Cardboard, corrugated, 38\% } \\
\text { recycled }\end{array}$ & 10.57 & 0.438 \\
\hline Packing & Process & & 0 & 0 \\
\hline & & $\begin{array}{l}\text { Natural gas, combusted in } \\
\text { industrial equipment; Electricity, } \\
\text { at grid, Washington, Oregon, } \\
\text { Nevada, Idaho, western Montana, } \\
\text { Wyoming, Utah }\end{array}$ & & 112.91 \\
Cooking & & & 308.32 & 21.758 \\
\hline TOTAL & Process & & & 7.623 \\
\hline
\end{tabular}

Potatoes-ShortDist-Cardboard-LandfillAfCooking

\begin{tabular}{|c|c|c|c|c|}
\hline NodeOrLink & Type & Mode & $\begin{array}{l}\text { Embodied } \\
\text { Energy }\end{array}$ & $\begin{array}{l}\text { Embodied } \\
\text { Carbon }\end{array}$ \\
\hline Packing <TO > Cooking & Transport & Transport, semi-trailer truck & 2.93 & 0.223 \\
\hline Cooking <TO > Waste Disposal & Transport & Transport, single-unit truck & 2.04 & 0.155 \\
\hline Raw Production & Process & Potatoes, California, USA & 179.87 & 13.32 \\
\hline Corrugated Cardboard & Process & $\begin{array}{l}\text { Cardboard, corrugated, } 38 \% \\
\text { recycled }\end{array}$ & 10.57 & 0.438 \\
\hline Packing & Process & & 0 & 0 \\
\hline Cooking & Process & $\begin{array}{l}\text { Natural gas, combusted in } \\
\text { industrial equipment; Electricity, } \\
\text { at grid, Washington, Oregon, } \\
\text { Nevada, Idaho, western Montana, } \\
\text { Wyoming, Utah }\end{array}$ & 225.83 & 15.245 \\
\hline Waste Disposal & Process & FoodWaste:Landfill & 0 & 8.658 \\
\hline TOTAL & & & 421.23 & 38.038 \\
\hline
\end{tabular}

Potatoes-ShortDist-Plastic-NoWaste 


\begin{tabular}{|l|l|l|l|l|} 
NodeOrLink & Type & Mode & $\begin{array}{l}\text { Embodied } \\
\text { Energy }\end{array}$ & $\begin{array}{l}\text { Embodied } \\
\text { Carbon }\end{array}$ \\
\hline Packing <TO> Cooking & Transport & Transport, semi-trailer truck & 1.6 & 0.122 \\
\hline Cooking <TO> Waste Disposal & Transport & Transport, single-unit truck & 0.24 & 0.019 \\
\hline Raw Production & Process & Potatoes, California, USA & 89.94 & 6.66 \\
\hline Polypropylene & Process & $\begin{array}{l}\text { Polypropylene, injection } \\
\text { moulding }\end{array}$ & 1.18 & 0.04 \\
\hline Packing & Process & & 0 & 0 \\
\hline & & $\begin{array}{l}\text { Natural gas, combusted in } \\
\text { industrial equipment; Electricity, } \\
\text { at grid, Washington, Oregon, } \\
\text { Nevada, Idaho, western Montana, } \\
\text { Wyoming, Utah }\end{array}$ & & 112.91 \\
\hline TOTAL & & & 205.87 & 7.623 \\
\hline
\end{tabular}

Potatoes-ShortDist-Plastic-CompostBfCooking

\begin{tabular}{|l|l|l|l|l|} 
NodeOrLink & Type & Mode & $\begin{array}{l}\text { Embodied } \\
\text { Energy }\end{array}$ & $\begin{array}{l}\text { Embodied } \\
\text { Carbon }\end{array}$ \\
\hline Packing <TO> Cooking & Transport & Transport, semi-trailer truck & 3.2 & 0.243 \\
\hline Cooking <TO> Waste Disposal & Transport & Transport, single-unit truck & 2.44 & 0.186 \\
\hline Raw Production & Process & Potatoes, California, USA & 179.87 & 13.32 \\
\hline Polypropylene & Process & $\begin{array}{l}\text { Polypropylene, injection } \\
\text { moulding }\end{array}$ & 2.36 & 0.08 \\
\hline Packing & Process & & 0 & 0 \\
\hline & & $\begin{array}{l}\text { Natural gas, combusted in } \\
\text { industrial equipment; Electricity, } \\
\text { at grid, Washington, Oregon, } \\
\text { Nevada, Idaho, western Montana, } \\
\text { Wyoming, Utah }\end{array}$ & & \\
Cooking & & & 300.78 & 21.451 \\
\hline TOTAL & Process & & & 7.623 \\
\hline
\end{tabular}

Potatoes-ShortDist-Plastic-LandfillAfCooking

\begin{tabular}{|c|c|c|c|c|}
\hline NodeOrLink & Type & Mode & $\begin{array}{l}\text { Embodied } \\
\text { Energy } \\
\end{array}$ & $\begin{array}{l}\text { Embodied } \\
\text { Carbon }\end{array}$ \\
\hline Packing $<\mathrm{TO}>$ Cooking & Transport & Transport, semi-trailer truck & 3.2 & 0.243 \\
\hline Cooking <TO > Waste Disposal & Transport & Transport, single-unit truck & 2.44 & 0.186 \\
\hline Raw Production & Process & Potatoes, California, USA & 179.87 & 13.32 \\
\hline Polypropylene & Process & $\begin{array}{l}\text { Polypropylene, injection } \\
\text { moulding }\end{array}$ & 2.36 & 0.08 \\
\hline Packing & Process & & 0 & 0 \\
\hline Cooking & Process & $\begin{array}{l}\text { Natural gas, combusted in } \\
\text { industrial equipment; Electricity, } \\
\text { at grid, Washington, Oregon, } \\
\text { Nevada, Idaho, western Montana, } \\
\text { Wyoming, Utah }\end{array}$ & 225.83 & 15.245 \\
\hline Waste Disposal & Process & FoodWaste:Landfill & 0 & 8.658 \\
\hline TOTAL & & & 413.69 & 37.732 \\
\hline
\end{tabular}


Chicken-Fresh-ShortDist-NoWaste

\begin{tabular}{|l|l|l|r|r|}
\multicolumn{1}{|c|}{ NodeOrLink } & \multicolumn{1}{c|}{ Type } & \multicolumn{1}{c|}{ Mode } & EmbodiedEnergy & EmbodiedCarbon \\
\hline Packing <TO> Cooking & Transport & Transport, single-unit & 4.37 & 0.333 \\
\hline Cooking <TO> Waste & Transport & Transport, single-unit & 0.1 & 0.008 \\
\hline Raw Production & Process & Chicken Meat, fresh, & 199.92 & 26.743 \\
\hline Corrugated Cardboard & Process & Cardboard, corrugated, & 6.56 & 0.272 \\
\hline PE Bags & Process & Polyethylene, general & 17.66 & 0.412 \\
\hline Packing & Process & & 0 & 0 \\
\hline Cooking & Process & Natural gas, combusted & 155.99 & 10.89 \\
\hline TOTAL & & & 384.6 & 38.657 \\
\hline
\end{tabular}

Chicken-Fresh-ShortDist-LandfillBfCooking

\begin{tabular}{|l|l|l|r|r|}
\multicolumn{1}{|c|}{ NodeOrLink } & \multicolumn{1}{c|}{ Type } & \multicolumn{1}{c|}{ Mode } & EmbodiedEnergy & EmbodiedCarbon \\
\hline Packing <TO> Cooking & Transport & Transport, single-unit & 8.74 & 0.666 \\
\hline Cooking <TO> Waste & Transport & Transport, single-unit & 2.81 & 0.214 \\
\hline Raw Production & Process & Chicken Meat, fresh, & 399.84 & 53.486 \\
\hline Corrugated Cardboard & Process & Cardboard, corrugated, & 13.13 & 0.544 \\
\hline PE Bags & Process & Polyethylene, general & 35.32 & 0.825 \\
\hline Packing & Process & & 0 & 0 \\
\hline Cooking & Process & Natural gas, combusted & 155.99 & 10.89 \\
\hline Waste Disposal & Process & FoodWaste:Landfill & 0 & 11.547 \\
\hline TOTAL & & & 615.82 & 78.17 \\
\hline
\end{tabular}

Chicken-Fresh-ShortDist-LandfillAfCooking

\begin{tabular}{|c|c|c|c|c|}
\hline NodeOrLink & Type & Mode & EmbodiedEnergy & EmbodiedCarbon \\
\hline Packing <TO > Cooking & Transport & Transport, single-unit & 8.74 & 0.666 \\
\hline Cooking <TO > Waste & Transport & Transport, single-unit & 2.78 & 0.212 \\
\hline Raw Production & Process & Chicken Meat, fresh, & 399.84 & 53.486 \\
\hline Corrugated Cardboard & Process & Cardboard, corrugated, & 13.13 & 0.544 \\
\hline PE Bags & Process & Polyethylene, general & 35.32 & 0.825 \\
\hline Packing & Process & & 0 & 0 \\
\hline Cooking & Process & Natural gas, combusted & 311.97 & 21.779 \\
\hline Waste Disposal & Process & FoodWaste:Landfill & 0 & 11.547 \\
\hline TOTAL & & & 771.79 & 89.058 \\
\hline
\end{tabular}

Chicken-Frozen-LongDist-NoWaste

\begin{tabular}{|l|l|l|r|r|}
\multicolumn{1}{|c|}{ NodeOrLink } & \multicolumn{1}{c|}{ Type } & \multicolumn{1}{c|}{ Mode } & EmbodiedEnergy & EmbodiedCarbon \\
\hline Packing <TO> Cooking & Transport & Transport, semi-trailer & 16.45 & 1.252 \\
\hline Cooking <TO> Waste & Transport & Transport, single-unit & 0.09 & 0.007 \\
\hline Raw Production & Process & Chicken Meat, fresh, & 166.57 & 22.282 \\
\hline Corrugated Cardboard & Process & Cardboard, corrugated, & 6.56 & 0.272 \\
\hline PE Bags & Process & Polyethylene, general & 36.13 & 0.33 \\
\hline Packing & Process & Electricity, at grid, & 155.99 & 2.626 \\
\hline Cooking & Process & Natural gas, combusted & 396.68 & 10.89 \\
\hline TOTAL & & & & 37.659
\end{tabular}

Chicken-Frozen-LongDist-LandfillBfCooking

\begin{tabular}{|c|c|c|c|c|} 
NodeOrLink & Type & Mode & EmbodiedEnergy & EmbodiedCarbon \\
\hline
\end{tabular}




\begin{tabular}{|l|l|l|r|r|} 
Packing <TO> Cooking & Transport & Transport, semi-trailer & 32.9 & 2.504 \\
\hline Cooking <TO> Waste & Transport & Transport, single-unit & 2.35 & 0.179 \\
\hline Raw Production & Process & Chicken Meat, fresh, & 333.14 & 44.564 \\
\hline Corrugated Cardboard & Process & Cardboard, corrugated, & 13.13 & 0.544 \\
\hline PE Bags & Process & Polyethylene, general & 28.25 & 0.66 \\
\hline Packing & Process & Electricity, at grid, & 73.78 & 5.253 \\
\hline Cooking & Process & Natural gas, combusted & 155.99 & 10.89 \\
\hline Waste Disposal & Process & FoodWaste:Landfill & 0 & 9.621 \\
\hline TOTAL & & & 639.54 & 74.213 \\
\hline
\end{tabular}

Chicken-Frozen-LongDist-LandfillAfCooking

\begin{tabular}{|l|l|l|r|r|}
\multicolumn{1}{|c|}{ NodeOrLink } & \multicolumn{1}{|c|}{ Type } & \multicolumn{1}{c|}{ Mode } & EmbodiedEnergy & EmbodiedCarbon \\
\hline Packing <TO> Cooking & Transport & Transport, semi-trailer & 32.9 & 2.504 \\
\hline Cooking <TO> Waste & Transport & Transport, single-unit & 2.36 & 0.179 \\
\hline Raw Production & Process & Chicken Meat, fresh, & 333.14 & 44.564 \\
\hline Corrugated Cardboard & Process & Cardboard, corrugated, & 13.13 & 0.544 \\
\hline PE Bags & Process & Polyethylene, general & 28.25 & 0.66 \\
\hline Packing & Process & Electricity, at grid, & 73.78 & 5.253 \\
\hline Cooking & Process & Natural gas, combusted & 311.97 & 21.779 \\
\hline Waste Disposal & Process & FoodWaste:Landfill & 0 & 9.621 \\
\hline TOTAL & & & 795.52 & 85.103 \\
\hline
\end{tabular}





\section{$\mathcal{S}$ O O T R R R C C}

P.O. Box 751

Portland, OR 97207

OTREC is dedicated to stimulating and conducting collaborative multi-disciplinary research on multi-modal surface transportation issues, educating a diverse array of current practitioners and future leaders in the transportation field, and encouraging implementation of 